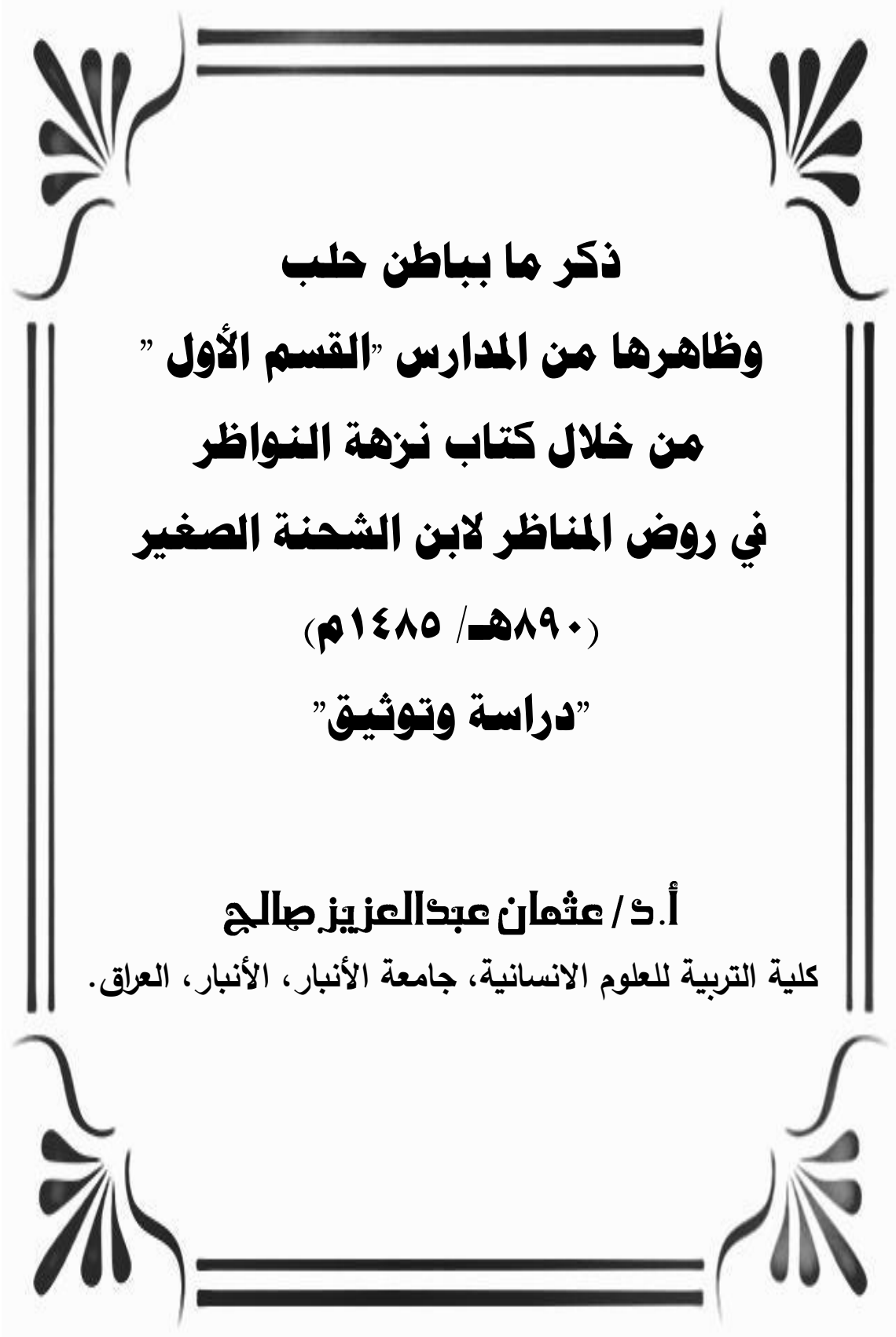


ذكر ما بباطن حلب وظاهرها من المدارس "المدارس الشافعية”<smiles>C=C=C</smiles>

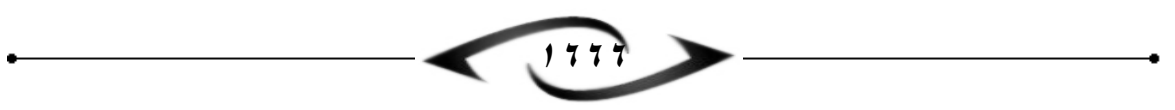


ذكر ما بباطن حلب وظاهرها من المدارس "المدارس الثافعية" من خلال كتاب نزهة النواظر في روض المناظر لابن الثحنة الصغير ( • (9هـ/

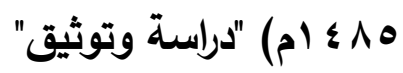

عثمان عبدالعزيز صالح كلية التربية للعلوم الانسانية، جامعة الأنبار، الأنبار، العرلق. البريد الإكتروني: d.othman.abdalazez@uoanbar.edu.iq ملخص: هدفت الدراسة إلى الوقوف على ما كان بمدينة حلب من مدارس من خلال دراسة وتحليل أحد المؤلفات التاريخية المهمة، لأن مؤرخي هذه الفترة عملوا من خلال مصنفاتهم على إظهار الدور الحضاري للأمة الإسلامية وإثبات أن الأمة مازالت أمة إبداع، وأن الإحتلال لم يتمكن من تدمير ثقافتها وآليات إبداعها الحضاري بل كان له أثر في دورها السياسي مدة معينة. ومن هذا المنطلق جاء إختيارنا لابن الثحنة الصغير ( •19هـ/ مــ (م)وكتابه نزهة النواظر في روض المناظر وهو لازال مخطوط، والذي تصدينا لتحقيقه كاملا والذي سيطبع قريبا إن شاء الله، فأردنا من هذا البحث الحديث عن ابن الثحنة الصغير والتعريف بكتابه فضلا عن تحقيق المدارس الثافعية الوارد ذكرها في الباب الثالث عشر من الكتاب المسمى في ذكر ما بباطن حلب وظاهرها من المدارس. واستخدمت الدراسة منهج تحقيق المخطوطات، وقد قسم البحث إلى مبحثين المبحث الأول تحدثا فيه عن سيرة ابن الشحنة الثخصية والعلمية والتعريف بكتاب نزهة النواظر في روض المناظر بشكل مختصر (') ، والمبحث الثاني النص المحقق. الكلمات المفتاحية: ابن الثحنة الصغير، نزهة النواظر، حلب، المدراس 
Theker Mi Babatin Hileb Wdhahrohi Mn Almadariss "Almadariss Alshafia" Via Nuzhat Al-Nawadher in Rawdh Al-Manadher Book of Ibin Shahna Al-Saqeer (1485 AD / 890AH) Investigation and Documentation

\section{Othman Abdalazez Saleh}

College of Education for Humanities, University of Anbar, Anbar, Aleiraq.

Email: d.othman. abdalazez@uoanbar.edu.iq

\section{Abstract:}

Conducting studies of historical works, in general, is important because it gives a clear picture of the development of the historical writing on the stage in which it was written, especially, these works appeared in the late centuries. They are considered an exceptional importance, because they represent significance phase in the life of nation due to the shift of the cultural activity center to Damascus and Cairo after the foreign invasion to Baghdad, as recorded by the ongoing outputs quantitatively and qualitatively.

In this sense, we chose the Ibin Al-Shahna Al-Saqeer (1485/ 890 H.) and His Book Nozhat Al-Nawader in Rawdh Al- Manadher and it still a manuscript. We have investigated the whole book and will be published soon. We hope from this research to present Ibin Al-Shahna AlSaqeer and present a definition of his book as well as to investigate chapter thirteenth to mention the schools inside and outside Aleppo "Almadariss Alshafia".

Keywords: Ibin Shahna Al-Saqeer, Nuzhat AlNawadher, Hileb, Almadariss Alshafia 


\section{المبحث الأول: سبرته الثخصية والعلمية:

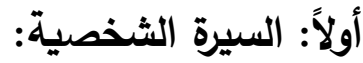

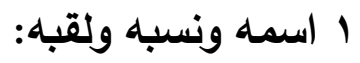

ابو الفضل محمد بن ححمد بن محمد بن خحمد بن محمود بن الثهاب غازي

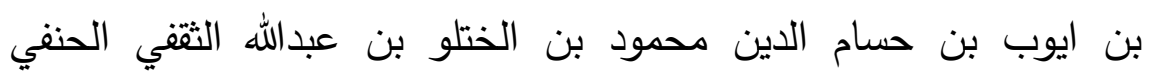

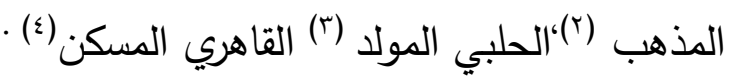

ولقب ابن الشحنة بالقاب عدة منها شمس الدين(*)، ومحب الب

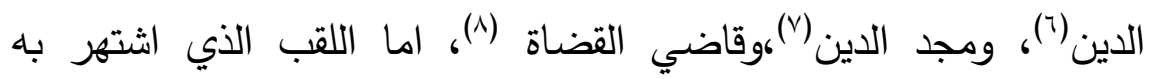
والذي عرفت به اسرته هو ابن الشحنة الصغير (9)، اما لقب ابن الثحنة

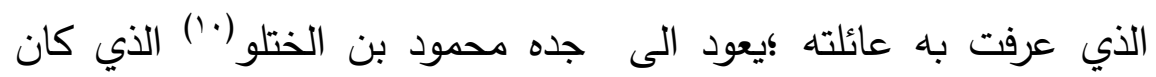

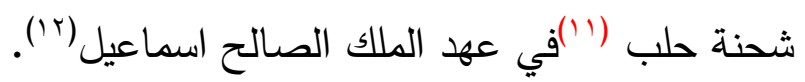
r ب الادته:

اتفقت معظم المصادر التي تحدثت عن ابن الثحنة على ان ولادته

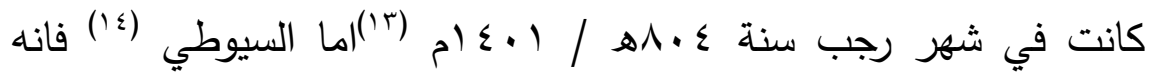
ذكر اليوم الذي ولد فيه قائلا (مولده يوم الجمعة ثاني عشر من رجب سنة ع • 1هـ/ 1 +ـ (م)، ، ولما بشر ابوه بولادته انثد

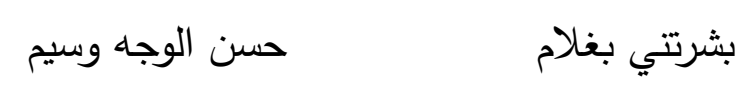

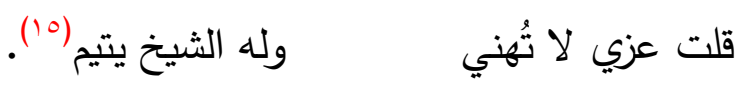
ب: اسرته ونشأته:

تعد اسرة ابن الثحنة من الاسر المشهورة في بلاد الثام ومصر لما لهم من مكانة متميزة عند المماليك من خلال نبوغهم العلمي الذي كان له له اثرا كبير في توليهم الوظائف الادارية المهمة، فجدهم حسام الدين محمود محير كان شحنة حلب في عهد الملك الصالح اسماعيل، والذي بنى المدرسة 


\section{ذكر ما بباطن حلب وظاهر ها من المدارس "المدارس الشافية"}

الحسامية(T1) المعروفة بإسمه لتدريس مذهب الامام ابي حنيفة النعمان وبنى الى جانبها مسجداً ، اما جده ابو الفضل محمد فقد تولى قضاء الحنفية في حلب اما كمال الدين ححمد بن ححمد بن محمود جد صاحب السيرة كان يعد من

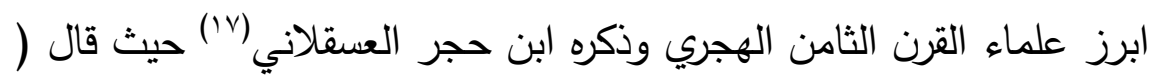

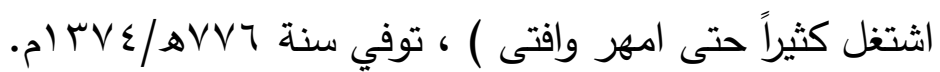

اما واللده فهو ححمد بن ححمد بن ححمد بن محمود بن غازي بن ايوب بن

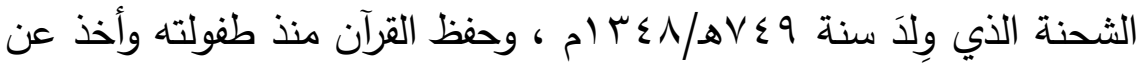
شيوخ بلده والقادمين اليها وارتحل الى دمشق والقاهرة وسمح له شيخه بالافتاء والتدريس ،اذ برع في الفقه والاصول والنحو ،ولهذا تولى قضاء الحنفية في حلب ثم دمشق ، وفي سنة ؟ ( 1هـ/ (ا إ ام تولى قضاء الحنفية بالقاهرة ثم عاد الى دمشق ليتسلم قضائها (1'). واثنى العديد من العلماء عليه منهم ابن تغري بردي الذي وصفه

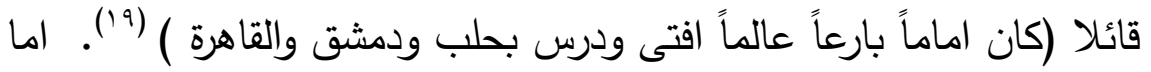
الشوكاني قال فيه (من افراد الدهر علماً وفصاحة وعقلاً ورئاسة ) (r."). توفي في حلب يوم الجمعة الثاني عشر ربيع الآخر سنة

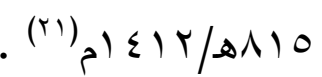

اما اعماماهُ فمنهم فتح الدين عبد الرحمن بن محمد بن محمد بن محمود

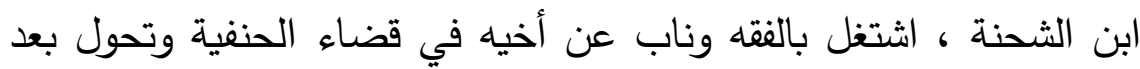
الفتنة التيمورية(r)ثم اصبح مالكي المذهب(rr) وتولى قضائهر مدة طويلة تزيد على العشرين سنة في حلب(؟)، ثم حصلت لله عزلة ونكد لإختلاف الدول وله شعر جيد منه : لا تلوموا الغمام ان صب دمعاً وتوالت لإجله الانـــواء 
فالليالي اكثرنَ فينا الرزايــا

\section{فبكت رحمةً علينا السمـاء(ro)}

وايضاً عمه الآخر علي بن ححمد بن محمد بن محمود بن غازي العلاء ابو الحسن بن الكمال الحلبي وعرف كسلفه بإبن الشحنة ، وِلد في

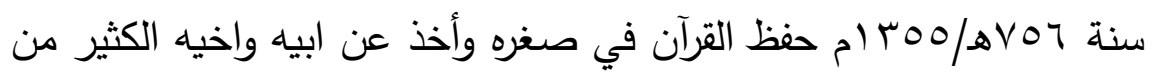
العلوم وناب عنهما في القضاء في بعض اجزاء حلب توفي

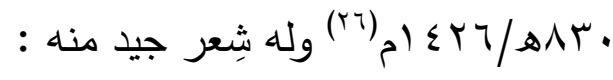

$$
\begin{aligned}
& \text { الهي قد نزلت بضيق لحدٍ }
\end{aligned}
$$

بأوزارٍ ثقالٍٍ مع عيوبٍ

وعفوك واسعٌْ وحماك حصنُ

وأنت الله غفار الذنوبٍ .

ولإبن الشحنة اشقاء كانت لهم مكانة مرموقة ومتميزة في الحياة العلمية والادارية دن خلال تقلدهم الوظائف المهمة في مصر وبلاد الثام

منهم الوليد بن الشحنة قال عنه السخاوي(rV( ) ( انه كان آية في الذكاء ) . وشقيقه الآخر هو عبد اللطيف بن ححمد بن ححمد بن حمح بن محمود

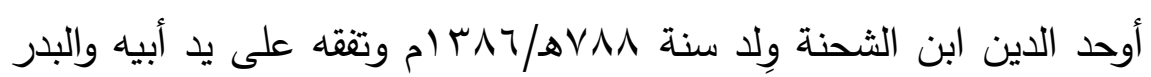

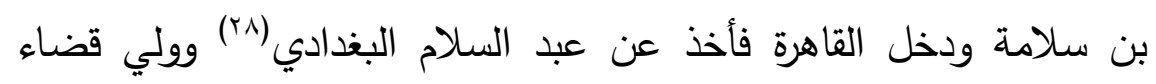
صفد ، ناب في القاهرة عن التفهني ومات فيها بمرض الطاعون سنة - (rq)

اما زوجاته فالاولى خديجة بنت العلاء علي بن ححمد بن سعد بن ححم

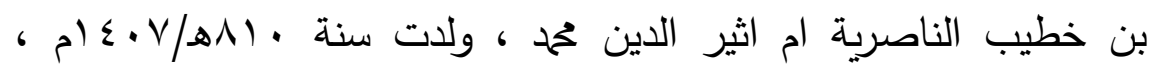

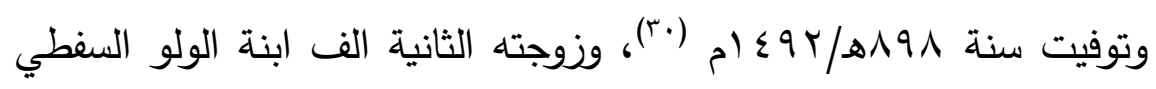




\section{ذكر ما بباطن حلب وظاهر ها من المدارس "المدارس الشافية"}

حمحد بن احمد بن يوسف بن حجاج ، والدة عبد البر وزينب وجورية، توفيت

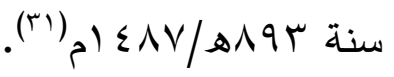

وكان لله عدة اولاد منهم تحمد بن محمد بن تحمد بن حمح بن ححمد بن

محمود اثير الدين بن المحب بن الثحنة ، الحلبي الحنفي سبط العلاء بن خطيب الناصرية ، امه خديجة ويعرف كسلفه بإبن الثحنة ولد في الثامن

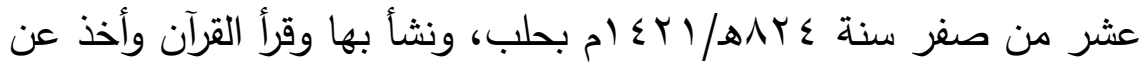
ابيه واناب عنه في القضاء بحلب وعمل ناظراً للجيش وناظراً لقلعة حلب

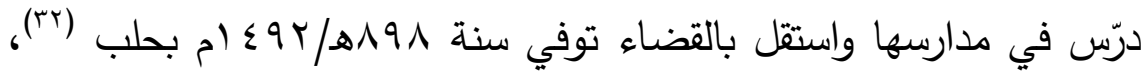
وعبد البر بن ححمد بن ححم تحمد بن محمد بن محمود ابن الثحنة وهو سبط

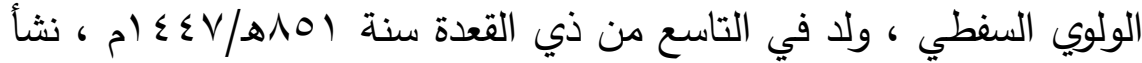
بحلب وانتقل الى القاهرة بصحبة والديه وحفظ القرآن ودرّس وكتب الكثير من الكتب وسافر الى القدس مع والده وسمع من علماءها، وزينب ابنة المحب محمد بن محمد بن تحمد ام الحياء ابنة ابن الثحنة شقيقة عبد البر امها الف بنت السفطي وزوجها يحيى بن الامير يشبك الفقيه ، توفيت

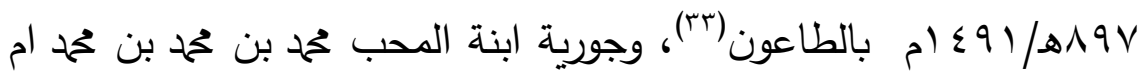
البهاء ابنة ابن الثحنة وشقيقة عبد البر وزينب وهي الصغرى تزوجها

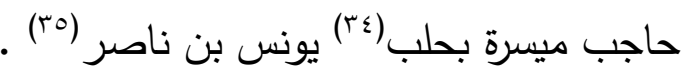
وتعد اسرة ابن الثحنة من الاسر العريقة التي كان لها الاثر الكبير

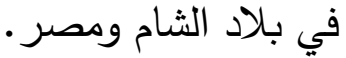
؛ : وفاته :

توفي ابن الثحنة في محرم سنة ، ـ19هـ/10 ام ، وصلى عليه في رحبة مصلى باب النصر ودفن بتربته، في القاهرة(ب؟) . 


\section{ثانياً: سيرته العلمية}

كان ابن الثحنة ومنذ نعومة اظافره متابعاً للعلماء يقطع المسافات

الطويلة للسماع منهم وهي صفة العلماء في ذلك الوقت وكان اول ما ابتدأ به مشوار معارفه هو القرآن الكريم والحديث النبوي الثريف والفقه وعلوم اللغة العربية والتاريخ حيث حفظ في اصول الدين وفي الحديث والسيرة ودرس الفقه واتم المختار، (rv) ، ويتميز ابن الثحنة بتنوع علومه وغزارتها من حيث العدد والفائدة حيث سأله عمهُ العلاء وهو بعمر اثنتي عشر سنة : اتحسن الوزن فقال له نعم فقال عارض لي قول الثاعر : امط اللثام عن العذال السابل

ليقوم عذري فيك بين عواذلي •

$$
\text { |كثال له بديهية : }
$$

لتموتن غبناً إن رأتك عواذلي (^^).

فأستحسن عمهُ ذلك كثيراً . 1.

ا : : بيوخه ورحلاته :

تميز العصر الذي ولد فيه ابن الثحنة بازدهار الحركة الفكرية في بلاد الشام في جميع جوانبها ولا سيما مدينة حلب اذ يقصدها طلاب العلم من مختلف البلاد الاسلامية فضلا عن مركز السلطنة في القاهرة وما تتمتعت به مصر من مركز علمي مرموق ،ان البحث عن المعلومة والسماع من كبار العلماء في عصره ، دفع محب الدين ابن الثحنة الى تحمل معاناة السفر في سبيل الوصول الى مبتغاه ، وان اول المحطات في حياة صاحب السيرة بدأت من حلب موطنه ومكان مولده اذ تتلمذ على يد علماء اجلاء منهم والده ابن الثحنة وعمه عبد الرحمن وكثير من علماء 
حلب ومن استحضرهم لله والده من مختلف البلدان المجاورة ومن شيوخه ابن الركاب شمس الدين(ra) حيث استمع منه الى القرآن الكريم في طفولته واخذ كذلك في بداية شبابه العلوم من علماء بلده ومنهم محمد بن العز

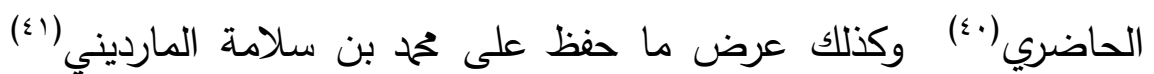

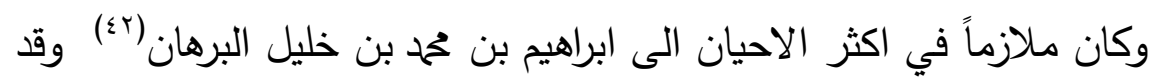
نصحه بالابتعاد عن المنطق وذكّره بأن جده الكمال كان يلوم ولده ابن الشحنة الكبير على التوسع فيه وكذلك تلقى العلوم في حلب بعد رجوعه من

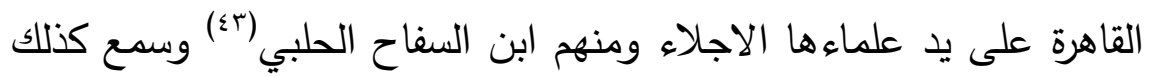
ابن الثحنة الصغير من علي بن محمد بن ابراهيم الحلبي(ء؛) وعندما ذهب

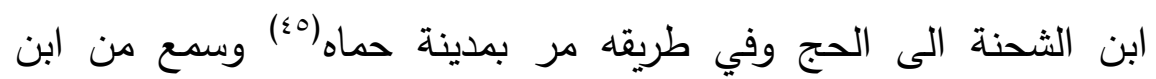
خطيب الدهشة(بء) وبعدها ذهب ابن الثحنة محب الدين الى دمشق وهذه الزيارة الثانية له حيث زارها وهو صغير بصحبة والده فسمع من بعض علمائها ومنهم علي بن عبد الله بن سلام (sv) ومن خحمد بن العلاء البخاري(^) ومن مدن الثام الاخرى التي زارها طلباً للعلم هي بعلبك(؟)؛

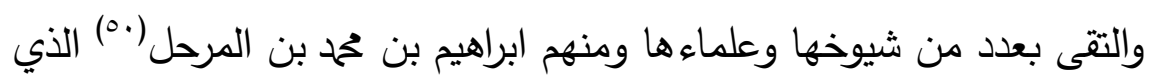

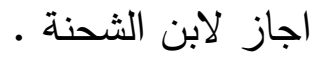
وسافر الى القدس سنة 101 هـ/ ؟0 ام وذلك بعد ان ابعد عن كتابة السر في مقر السلطنة مصر ، ويقول السخاوي(1) : قابلته بنفسي هناك حيث لقيته ( على طريقة حسنة من العبادة والتلاوة والاشتغال والاشغال ، حيث اخبرني انه يختم القرآن الكريم كل يوم ...) و جَود القرآن بحضرة الشمس بن عمران(r) شيخ القراء هناك وانه يكتب في كل يوم

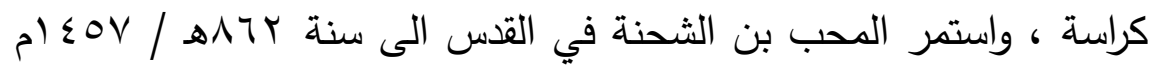
حيث خُيرَ بين الرجوع الى المملكة الحلبية او الرجوع الى مقر السلطنة 
مصر فأختار الرجوع الى بلده حلب، وكذلك اخذ عن ابن حجر العسقلاني في آمد ومما يذكر انه كان قد راسله من اجل الحصول على اجازة منه سنة

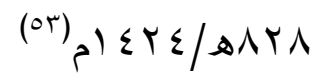

اما القاهرة فإنها كانت الموطن الثاني له وذلك لقضاء شطراً من حياته فيها بعد توليه وظائف إدارية فيها وكذلك لأنها كانت مركز السلطنة وملتقى العلماء والفقهاء ومن الثخصيات التي التقى بهم علي المقريزي(؛ُه) وقاسم بن قطلوبغا الزين(00) وسمع من الثاب التائب احمد بن عمر (0r) الفقيه المصري.

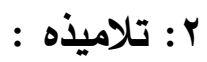

تتلمذ على يد ابن الثحنة الصغير العديد من طلبة العلم سواء كان

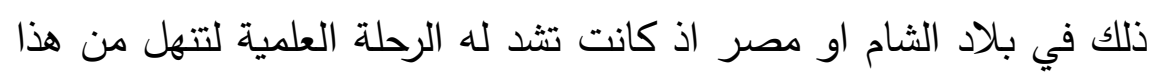
المعين الثري الذي لا ينضب ومن ابرز طلبته ابي ذر الحلبي موفق الدين

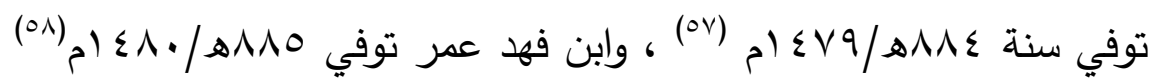

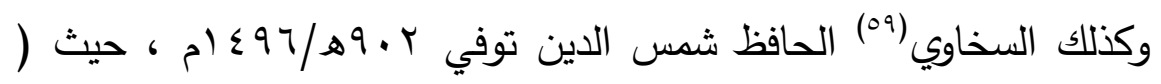
... أخذ قطعة من القاموس في اللغة تحريراً واتقاناً مع المحب بن الشحنة ) (7r.) وأخذ عنه ايضاً احمد بن محمد بن الثهاب الرملي توفي سنة

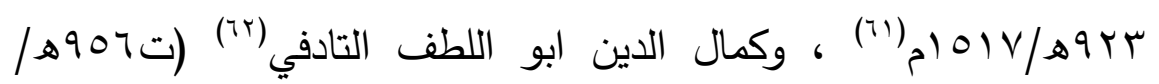
9 90

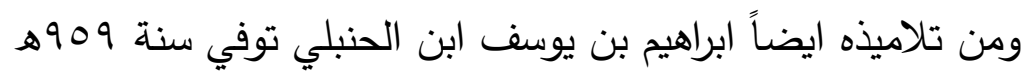

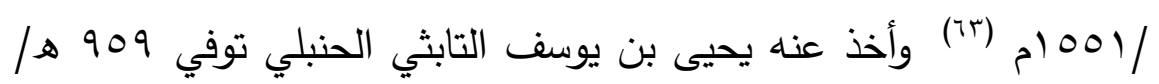
(Ts) 1001 
ومن تلاميذه ايضاً بدر الدين ابو الفتح عبد الرحيم العباسي توفي

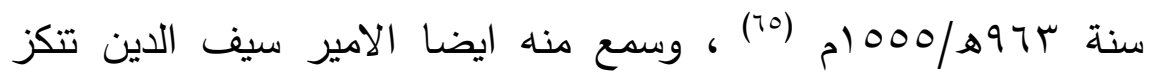

الحسامي (T7).

ץ: مصنفاته:

يعد ابن الثحنة من المؤلفين الذين اتصفوا بغزارة انتاجهم العلمي بالرغم من توليه وظائف عدة الا ان هذا لم يمنعه من تصنيف المؤلفات القيمة في المجالات المختلفة التي ساهدت في إزدهار الحركة العلمية في عصره والعصور اللاحقة ومنها :

ا . نهاية النهاية في شرح الهداية. كتب منه الى اخر فصل

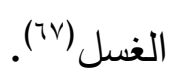

r. استقصاء النهاية ـ اختصرها محب الدين ابن الثحنة بألف

بيت مع زيادة مذهب الامام أحمد (T^).

r. نزهة النواظر في روض المناظر (79) .

ع. اختصر كتاب والده روض روص المناظر وسماه اقتطاف

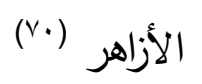

ه. منظومة في الصلاة الوسطى شرحها وجعلها كتاباً (VI).

$$
\begin{aligned}
& \text { 7. طبقات الحنفية: كتبها في عدة مجلدات (Vr). }
\end{aligned}
$$

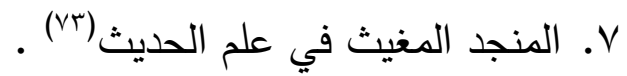

^. ترتيب مبهمات ابن بشكوال في أسماء الصحابة. وقال ان

شيخه البرهان اشار عليه بذلك (ع (Y).

9. الفية في عشر علوم (vo).

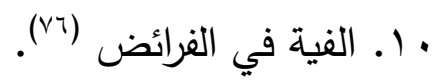


11ا. السير المنير في اصول البسط والتكسير • سير النبي حمح

صلى الله عليه وسلم (VV).

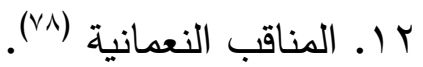

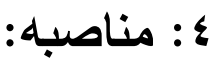

تولى محب الدين ابن الثحنة الكثير من الوظائف في مصر

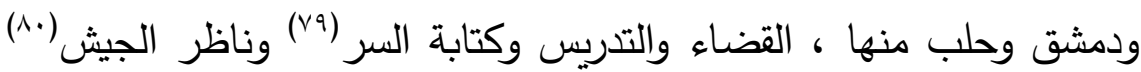
وغيرها من الوظائف الادارية الاخرى، ومما يذكر ان ابن الشحنة كان يجمع عدة وظائف في وقت واحد مثل جمعه كتابة السر والقضاء الحنفي وناظر

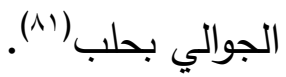

أ:القضاء :

تولى ابن الثحنة القضاء في مصر وحلب ولا سيما قضاء

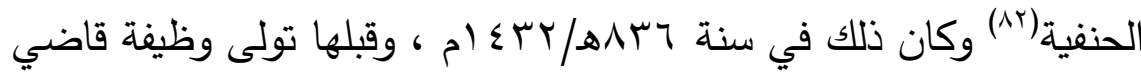

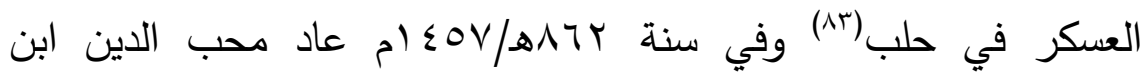
الشحنة الى حلب قادماً من القدس بعد ان اختارها وفضلها على القاهرة فأقام بها دون وظيفة بعد رفضـه وظيفة قضاء الحنفية في حلب وإعطائها الى ابنه

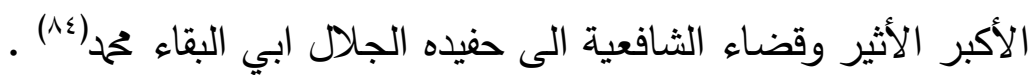
وحاول بعد عودته الى مصر جمع وظيفة كاتب السر مع وظيفة قاضي الحنفية هناك ولكنه فثل بذلك بسبب المنافسة القوية ولكنه حصل

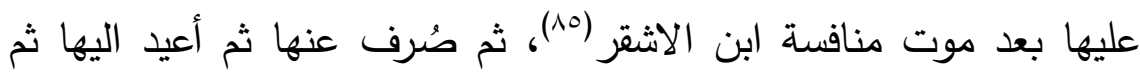

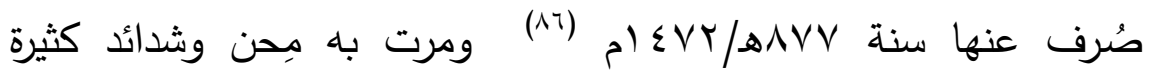
واصابه الذهول آخر عمره ، وتوفي وهو شيخ الخانقاه الثيخونية في القاهرة(^V) 


$$
\begin{aligned}
& \text { ويذكر الشوكاني( (ان) ( انه ولي قضاء حلب وكثيراً من امورها حتى } \\
& \text { صار المرجع اليه في غالب الأشياء ) . } \\
& \text { ب: بتابة السر : }
\end{aligned}
$$

تولى محب الدين ابن الثحنة الصغير كتابة السر في مصر بعد أن تعرض الى مشاكل كثثرة في حلب بعد إتهامه بتقديم الاموال الطائلة للحصول على الوظائف فخرج عليه أبناء حلب فقرر الذهاب الى دار السلطنة في مصر سنة 10Vهـ/Or ام وولي كتابة السر فيها بعد دفعهُ الاموال والهدايا الى السلطان ، (^9) ولكن المقام لم يطول به ولم يكمل سنة حيث اعيد محب الدين ابن الأشقر الى كتابة السر ، وكانت بينه وبين ابن الثحنة منافسة قوية في سبيل الحصول على وظيفة كاتب السر ثم نفي الى بيت المقدس وعاد الى حلب وبعدها قرر الذهاب الى القاهرة والحصول على وظيفة كاتب السر مرة ثانية وفعلاً تم له ما يريد بعد دفعه مبالغ كبيرة الى السلطان مقابل الحصول على تلك الوظيفة التي كانت مفضلة عنده بسبب قربه من السلطان ومن يحصل عليها يعتبر الثخص الثاني بعد السلطان

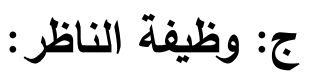

ومن الوظائف الادارية الاخرى التي تولاها ابن الثحنة هي ناظر الجوالي(19) و ناظر جيش حلب وناظر قلعتها وناظر الجامع النوري واصبح المتصدر لله والخطيب فيه واصبحت امور مملكة حلب كلها بيده وعظمة مكانته وصفاته وشهرته في كل مكان (rون. وهذا العدد الكبير من الوظائف التي حصل عليها ابن الشحنة جعلت منافسيه يثيرون القلاقل والفتن حسداً وطمعاً في الحصول على لوطى 
بعضها وطريقة دفع الاموال الى السلاطين كانت شائعة ومنتشرة في ذلك الوقت في سبيل الحصول على الوظائف المرموقة (rهو). د: وظيفة التدريس :

من أول الوظائف التي تولاها ابن الشحنة هي التدريس في مدارس

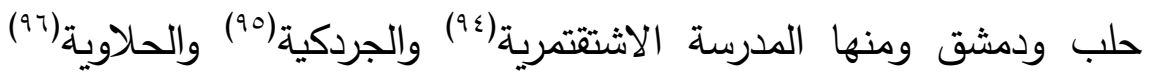

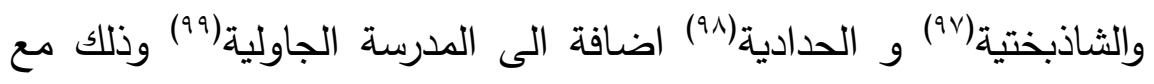
أخيه عبد اللطيف برغبة من والدهما قبل موته(.') ولم يترك إبن الثحنة التدريس بالرغم من انشغاله بوظائفه الكثيرة في مصر وبلاد الثام وفي سنة

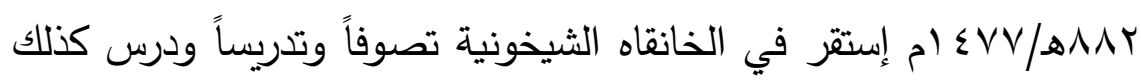
الحديث في المدرسة المؤيدية(1) ثم تزايدت عليه صعوبة الحركة وصعوبة التتقل فأستخلف ولده على الثيخونية والمؤيدية الى ان اجبره المرض على له الانقطاع عن صلاة الجمعة وأستمر على ذلك الحال الى ان توفي سنة - م) $\leqslant 10 / 8 \wedge 9$.

\section{0 : آراء العلماء فيه :}

يعد ابن الثحنة الصغير من العلماء البارزين الذي انجبتهم المائة التاسعة اذ بلغ علمه وذكائه منزلة فريدة ومحسودة واشاد به كبار العلماء

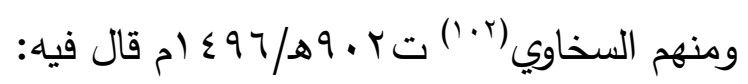

( فصيح العبارة غاية في الذكاء وصفاء القريحة بديع النظم والنثر ... محب في الحديث وأهله لديه حلاوة المنطق وحسن المعاشرة والصحبة وإستجلاب الخواطر مائل الى النكتة اللطيفة والنادرة راغب في الكماليات الدنيوية وانواع الشرف والكمال بهي المنظر حسن الثاكلة ذو نفس أبية وهمة عالية ورئاسة وكياسة وتهجد وصبر على المحن والرزايا وقوة الجأش 
ومبالغة في البذل ليتوصل الى اغراضده الدنيوية) (r.1) ، اما السيوطي(ع.() قال عنه ( تققه وتفنن، واعتنى بالادب ونظم الشعر الحسن وانشأ النثر).

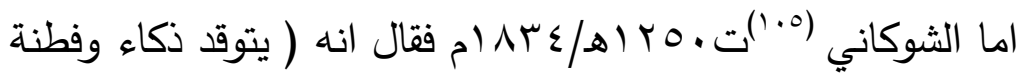
وكان فصيحاً ذا رئاسة وحشمة وافرة وجلالة عند السلاطين وأبها زائدة وميل الى المناصب والقدرة على تحصيلها ودراية في كل ذلك ).

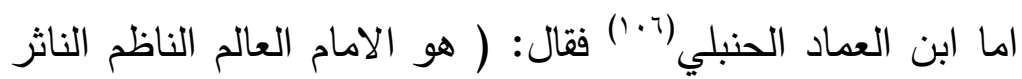

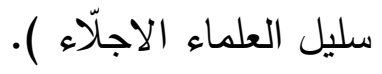
المبحث الثاني: التعريف بالكتاب وخطته: اـ تسمية الكتاب ونسبته للمؤلف: اتفقت المصادر التي ترجمت لابن الثحنة ان له كتاب باسم(نزهة النواظر في روض المناظر) منها ما ذكره حاجي خليفة في كتابه كثف الظنون(v•(1) حيث قال(نزهة النواظر في روض المناظر لقاضي القضاة محب الدين ابو الفضل ححمد بن حمحد بن حمح بن محمود بن الثحنة الحلبي الحنفي ... وهو تاريخ كبير جعله كالثرح لتاريخ والده المسمى روض المناظر في علم الاوائل والاواخر). فضلا عن ان عنوان المخطوط دون في بداية نسخ المخطوط التي قمنا بتحقيقها باسم (نزهة النواظر في روض المناظر). الا ان الغزي خالف الجميع وذكره في كتابه نهر الذهب في تاريخ حلب(^•) باسم (نزهة الناظر في روض المناظر). r ب دوافع التأليف: لغرض معرفة دوافع التأليف لدى ابن الشحنة لابد من الرجوع الى لى

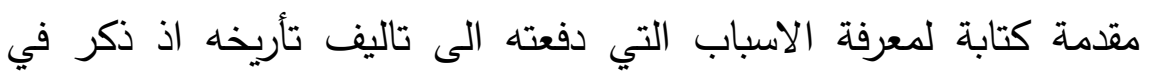
المقدمة ان الهدف الاساسي من التاليف هو الحفاظ على تاريخ والده 
المسهى (نزهة النواظر في علم الاوائل والاواخر) وتهذيبه بعد ان قام الناسخ الاول بالتقديم والتاخير في الروايات والاحداث التاريخية كما انه زاد ونقص التص في بعضها مما ترتب على هذا الامر من مفاسد وقد نصحه علماء عصره ومنهم شمس الدين القرماني على تهذيبه والاشارة الى الزيادات فيه ، وذكر (... فان سيدي شيخ مشايخ الاسلام الوالد ... سأله بعض طليه والبته من ابناء الامراء ... اختصار تاريخ جدهُ... وسماه روض المناظر في علم الاوائل والاواخر(9.1) غير ان الناقل الاول نقل من مسودة سيدي الوالد فقدم واخر وزاد ونقص فترتب على ذلك مفاسد وكان صاحبنا الشيخ العلامة شمس الدين القرماني ... اشارة ان انبه على ما زادة الناسخ وما اهمل

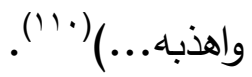

وعليه فان دافع محب الدين ابن الثحنة الصغير في تأليف كتابه هو الحفاظ على تاريخ والده وتهذيبه من المفاسد والزيادات والنقصان وكذلك اضافة ما استجد من الحوادث بعد وفاة والدة في القرن التاسع الهجري. ومما يشار اليه ان ابن الثحنة عمل اختصار كتاب روض لهاه

المناظر وسماه اقتطاف الأزاهر ذيل روض المناظر (1') r- وصف المخطوط ومحتواه:

ابتدأ مؤلف المخطوط محب الدين ححم ابن الثحنة كتابه ( نزهة النواظر في روض المناظر) بمقدمة بيّن فيها بعد البسملة والحمد الله والصلاة والسلام على نبينا حمح صلى الله عليه وسلم والثناء عليه وآله بيان

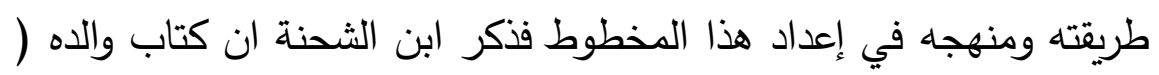
نزهة النواظر في علم الاوائل والاواخر ) مرتب على مصراعين ومقسم الى ثلاث فصول وخاتمة وذكر ان الفصل الأول: جاء في ذكر الالفاظ التي لا بد للمؤرخ من ذكرها وهي الزمان والدهر والعصر والحين والسنة والثهر 
والاسبوع واليوم والساعة والليل والنهار والوقت والمدة، والفصل الثاني:

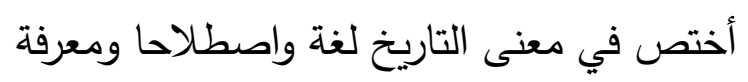

والفصل الثالث : في ذكر شرف التاريخ وفائدته وجاء في الخاتمة التتبيه على سبب وقوع الخطأ في بعض التواريخ(ז'ا') ثم ذكر محب الدين ابن الشحنة ان الناقل الاول الذي نقل من مسودة كتاب والده زاد ونقص من الكلام فترتب على ذلك مفاسد كبيرة وقد اشار عليه بعض العلماء ان ينبه على ما زاد الناسخ الاول واهمل فقرر صاحب السيرة ان يهذبه ويضيف اليه كما فعل الامام عبد الله بمسند والده احمد بن حنبل، فشرع في ذلك مضيفاً له الكثير من العلوم والاخبار التي استجدت في القرن التاسع بعد وفاة والده ، وقد رتب صاحب السيرة كتابه بعد التهذيب والاضافة فقسم المصرع الاول الى ثلاثة فصول الاول في خلق آدم عليه السلام وذريته والفصل الثاني في طبقات الامم والفصل الثالث في المبشرات الواردة في التوراة والانجيل لمولد نبينا تحمد صلى الله عليه وسلم ، وقسم المصرع الثاني الى تسع طبقات وجعل كل قرن من القرون طبقة يذكر فيها اشهر الحوادث مرتبة على السنين وقد ابتدأ القرن الاول بسيرة الرسول ححم صلى الله عليه وسلم وخلفاءه واصحابه رضي الله عنهم ثم تبعه بوفاة الاعيان المشهورين وضبط ما فيه من لفظ عربي وذيّل عليه ما استجد في القرن التاسع وذكر بأنه تاريخ مستقل وشرح لتاريخ والده وقد سمّاه ( نزهة النواظر في روض المناظر )

رابعا: أهمية المخطوط

يعد كتاب نزهة النواظر في روض المناظر من الكتب التاريخية المهمة لما حواه من معلومات مهمة تحدثا عنها في وصف المخطوط ،لانه عاصر احداث تاريخية مهمة والتي عمل على تدوينها مرت بها مصر 
وبلاد الثام خلال عصر المماليك الثاني لاسيما السياسية منها تعرض البلاد الاسلامية لغزو تيمورلنك وكذلك ظهور العثمانيين في هذه الفترة الذين عملوا على السيطرة مصر وبلاد الثام والبلاد العربية الاخرى فضلا عن الجوانب الاقتصادية والاجتماعية التي ذكرها . وتكمن اهمية الكتاب فأن العلماء الذين اتو من بعده استفادوا من كتابه نزهة النواظر من خلال اخذ المعلومات منه او اختصاره كما فعل زين الدين احمد بن علي بن الحسين بن علي الشعيفي على اختصار نزهة النواظر والتي توجد نسخة منه في مكتبة الفاتيكان(ع (l) وكذلك اختصره ابواليمن البتروني المتوفي 7؟ ـ 1 هـ واضاف اليه الاحداث التي جرت في عصره ووضع له فهارس ،وكذللك اختصره احمد بن محمد المعروف ابن الملاج(110) كذلك كمنت اهمية الكتاب من خلال الاختلاف حول نسبة كتاب (الدر المنتخب في تاريخ مملكة حلب ) لمن ،وهل هو من تأليف صاحب السيرة محب الدين بن الشحنة (ت . 9^هـ/ ا • ع (م) ام هو احد فصول (نزهة النواظر في روض المناظر) واذا كان كذلك لماذا لم يذكره المؤرخون المعاصرون لابن الشحنة الصغير مثل السخاوي ، او الذين جاء بعده بفترة قريبة ، وقد تضاربت الاراء حول ذلك . فقد ذكر الغزي (ت اهب اهـ/rrو ام) في كتابه ( نهر الذهب في تاريخ حلب ) انه يشكك في نسبته الى ابن الثحنة وذلك لان مقدمة هذا

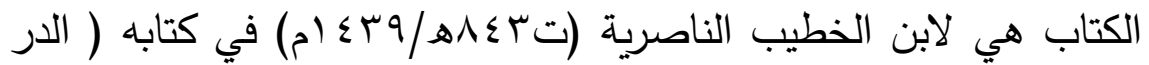
المنتخب في تاريخ مملكة حلب ) مع بعض التحريف البسيط (1'ا')، وينفي الغزي ان يكون هذا الكتاب الى ابن الثحنة او على صلة بروض المناظر في نزهة النواظر ويقول انما هو تأليف جماعي لعدد من الادباء 
والعلماء('lv) ، حيث اخذوا خلاصة من كتاب ابن شداد وكتاب ابن الشحنة وكتاب ابن المنلا واضافوا عليه بعض الحوادث التي استجدت في عهدهم ثم اصبح كتاباً مستقل دون ان ينسبه الى احد ومما يؤكد رأيه هو عدم وجود

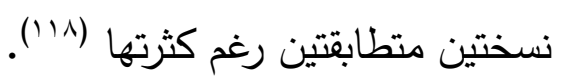

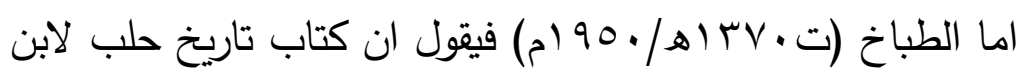

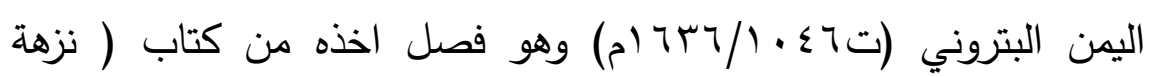
النواظر في روض المناظر ) لابن الثحنة الصغير وانه ابقى العبارات التي تخص صاحب السيرة على حالها (19') ، والدليل على ذلك بعض العبارات التي وردت في الكتاب باسم البتروني ويذكر انه لو كان هذا الكتاب لابن الثحنة لذكره معاصريه ومن جاء من بعده مثل رضي الدين الحنبلي

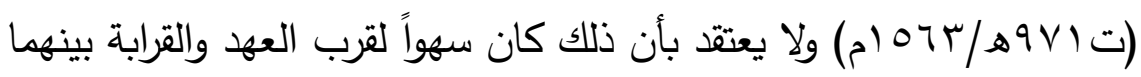

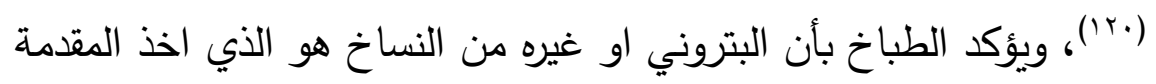

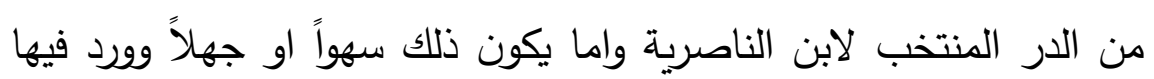
اسم الدر المنتخب فأشتهر الكتاب بهذا الاسم (Irا'). اما يوسف اليان سركيس الدمشقي الذي علق على كتاب البتروني فيقول ان هذا الكتاب هو لابن الثحنة وبعد اكثر من . 10 سنة قام بجمعه البتروني وزاد فيه حوادث جرت بعد وفاة المؤلف ابن الثحنة ، والدليل على هلى ذلك يتضح من الحواشي التي علق عليها البتروني على انه هو ناقل تاريخ

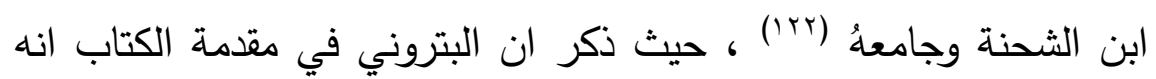
نقل نبذه من كتاب نزهة النواظر في روض المناظر وهذا ما أكده المحقق الئرن الاخر الذي حقق نفس الكتاب بعد Vo سنة وهو عبد الله محم درويش الذي طبع الكتاب سنة عـ919 م بنفس الترتيب الا ان طبعته تميزت عن نسخة 
سركيس بأن صفحاتها كانت اكثر مع ذكر ترجمة عن ابن الشحنة الصغير و نبذة مختصرة عن البتروني و سركيس(rr) . . وكذلك قامت الباحثة كيكو اوتا اليابانية بتحقيق الكتاب وتتاولت الاختلاف في نسبة الكتاب بشيء من التفصيل ، اذ تقول ان كتاب الدر المنتخب في تاريخ حلب هو فصل من كتاب ابن الثحنة نزهة النواظر الذي تحدث عن حلب وجعل لها فصل في الكتاب ، وذكرت بأن شخص من آل الثحنة استل هذا الفصل واضاف اليه ما استجد من امور عصره وهذا ما اوقع اللبس كون الذي اضاف يحمل نفس اللقب وهذا الناسخ اصبح لزاماً عليه ان يأتي بمقدمة فجاء بمقدمة كتاب ابن الخطيب الناصرية ( الدر المنتخب ) ومقدمة ثانية اخذت من نزهة النواظر ، وقد اوهم هذا بأن هناك كتاب لابن الشحنة الصغير بإسم الدر المنتخب في تاريخ حلب في حين لم تذكر المصادر هذا الاسم في سرد مؤلفات ابن الثحنة ولم يذكرها معاصروه وأخيراً تؤكد كيكو اوتا نسبة هذا الكتاب الى صاحب السيرة لانه فصل من كتابه نزهة النواظر في روض المناظر ، كما انفردت كيكو اوتا بإعطاء اسم جديد لكتاب الدر المنتخب لانهاء الجدل اسمته ( تاريخ حلب لابي الفضل محمد بن الثحنة المتوفي سنة ـوحهـ وهو فصل من كتابه نزهة النواظر في روض المناظر انتخبه ابن الشحنة المجهول وعلق عليه ابواليمن البتروني

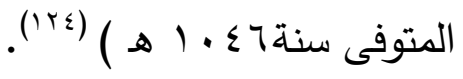

وذهبت الباحثة جنان الثمري الي ما جاءت به الباحثة كيكو اوتا وبتقيل اكثر واثبتت بأن الدر المنتخب فصل من كتاب نزهة النواظر لابن الثحنة الصغير ، والف من قبل احد علماء آل شحنة في القرن

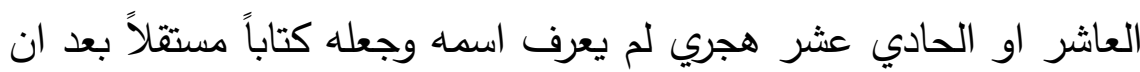
اضاف ما استجد من امور عصره وهذا ما اوقع اللبس بين ابن الشحنة 
المجهول وابن الثحنة محب الدين بعد ان اخذ مقدمة من الدر المنتخب لابن الخطيب الناصرية ومن كتاب بغية الطلب لابن العديم ومقدمة من نزهة النواظر فأوهم بأن هنالك كتاب مستقل في تاريخ حلب لابن الشحنة

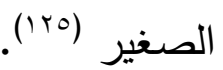

وبناء على ما تقدم نذهب ما ذهبت اليها الباحثتين كيكو اوتاو وجنان الشمري بان الدر المنتخب فصل من كتاب نزهة النواظر لابن الشحنة الصغير ، وعمل جامعه على اختصاره اذ بعد الاطلاع على مخطوط نزهة النواظر وجدنا فيها ليس بالقليل الاختلافات في ذكر المعلومات كالحديث عن مدارس في حلب وغيرها من المعلومات ، فضلا عن ان عدد ابوابه مختلفة اذ في نزهة النواظر ع ب باب وفي الدر المنتخب 10 باب ،وهذا الاختلاف يدلل على اهمية الكتاب بما حواه من معلومات مهمة فالبعض اختصره او استفاده منه في مؤلفه.

خامساً: وصف النسخ الخطية المعتمدة في التحقيق : النسخة (أ) : (l)

العنوان : ( نزهة النواظر في روض المناظر )

المؤلف : ( تحمد بن تحمد بن تحمد بن حمح بن محمود بن الختلو بن الثحنة ) اولها : ( الحمد لله وارث السموات والارض وباعث الاموات للعرض ) نهايتها : ( والحمد الله وحده وصلى الله على من لا نبي بعده سيدنا حمح صلى الله عليه وسلم) تاريخ النسخ : في اواخر شهر جمادي الاخر سنة بr الهـ/ • الام. اسم الناسخ : محمد بن عبد الله الحموي الحلبي • نوع الخط : نسخ معتاد واضح • لغة الخط : اللغة العربية . 


$$
\begin{aligned}
& \text { حالتها : جيدة وسليمة وكاملة . }
\end{aligned}
$$

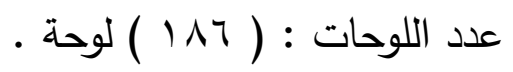

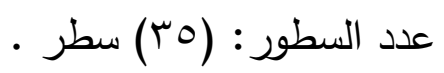

$$
\begin{aligned}
& \text { قياس المخطوط : ( ع (ا× •( سم ) • } \\
& \text { عدد الكلمات في السطر الواحد ( (1-س |) . } \\
& \text { مصدر المخطوط مكتبة السليمانية - تركيا . }
\end{aligned}
$$

الجزء المحقق من المخطوط (ذكر ما بباطن حلب وظاهرها من المدارس

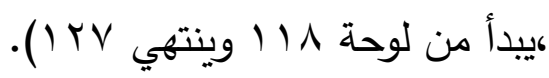

$$
\begin{aligned}
& \text { النسخة (ب) : }
\end{aligned}
$$

العنوان : ( نزهة النواظر في روض المناظر )

المؤلف : ( كحمد بن محمد بن محمد بن محمد بن محمود بن الختلو بن الثحنة )

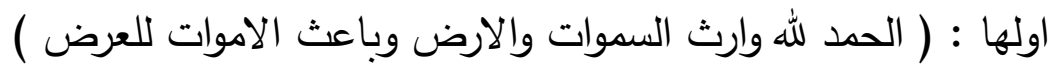
نهايتها : ( والله الموفق بمنه وكرمه تم الكتاب بعون الملك الوهاب ) .

تاريخ النسخ : مجهول

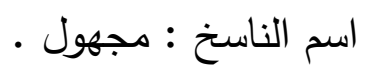

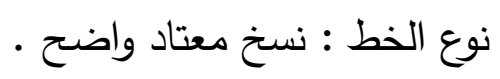
لغة الخط : اللغة العربية . حالتها : جيدة سليمة وفيها بعض الكلمات الساقطة والممسوحة .

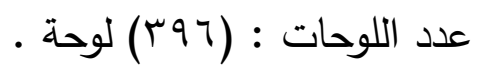

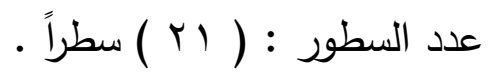

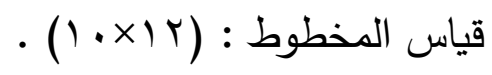
عدد الكلمات في السطر : ( مصدر المخطوط : مكتبة السليمانية - تركيا . 
الجزء المحقق من المخطوط: (ذكر ما بباطن حلب وظاهرها من المدارس

$$
\text { سيبدأ من لوحة بساً: منهجنا وينتهي ف00).. }
$$

سرنا بنفس خطوات من سبقنا من المحققين في هذا المجال وقمنا

$$
\text { بتحقيق هذا المخطوط وحسب توجيهات اساتذتنا . }
$$

وإن سبب تحقيق أي مخطوط هو الرغبة في احياءه واعادته الى

الوجود من سباته الطويل على رفوف المكتبات ليكون في متتاول القراء

والباحثين ومن اهم الخطوات المستخدمة في تحقيق هذا المخطوط هي : قمنا بمحاولة قراءة المخطوط قراءة جيدة والتعرف على منهجية واسلوب

مؤلفها .

قمنا بترجمة المؤلف فيما يخص اسمه والقابه وشهرته وولادته ومؤلفاته ووظائفه التي تولاها طيلة حياته . اشرنا في المتن الى نهاية كل ورقة من النسخة الاصل بوضع رقها بين

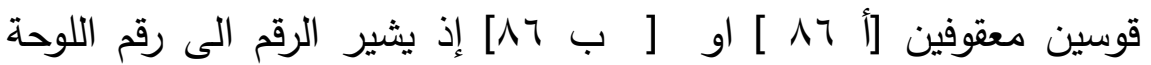
والحرف الى وجه اللوحة وظاهرها .

قمنا بنسخ المخطوط ومن ثم كتابته بطريقة الاملاء المعاصر والمفهوم

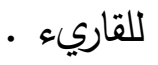

قمنا بتغير رسم بعض الكلمات الاملائية والتي كانت سائدة في وقتهم وجعلها تتناسب مع ما هو سائد في وقتنا الحالي مثل الالف الوسطية (مائ اسمعيل - اسماعيل ) ووضع الياء بدل الهمزة مثل ( أوايل - اوائل ) و ( ) وائل مايه - مائه ) او حذف الالف الواقعة بعد اللام مثل ( الثلثاء - الثلاثاء )

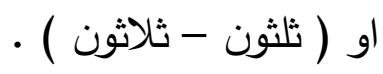

الاضافات والتصويبات والفروق بين النسختين كثيرة جداً . 
بينا معاني الكلمات العربية والمصطلحات التي كانت سائدة في ذلك الوقت بواسطة الرجوع الى معاجم وكتب اللغة العربية . ترجمنا أسماء الاعلام الواردة في هذا المخطوط وذلك من كتب التراجم

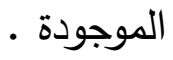

قمنا بتخريج الايات القرآنية من القرآن الكريم وذكر اسماء السور القرآنية

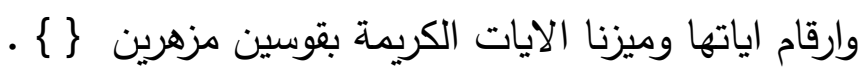

تم تخريج الاحاديث النبوية الثريفة من كتب الصحاح وكتب السنة النبوية . حاولنا جاهدين ان نوثق النصوص من الكتب التي نقل منها المؤلف وعند فقدان هذه الكتب وثقنا من كتب اخرى ذكرت نفس النص . عرّفنا البلدان والاماكن التي ورد ذكرها في المخطوط من كتب الجغرافيا • والبلدان قمنا بنسبة الابيات الشعرية الى اصحابها ودواوينها ـ وضعنا الاقواس المعقوفة [ ] ] لما يضاف الى الاصل من النسخة الاخرى

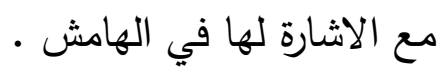
اشرنا في الهامش في حالة وجود اختلاف بين نسخه أ والنسخة ب . في حالة اذا كان هناك سقط في احدى النسختين فنوضتح ذلك في الهامش مع ذكر الكلمة او النص المفقود . 
ذكر ما بباطن حلب وظاهرها من المدارس "الملدارس الشافية"

استخدمنا بعض الرموز في المخطوط وهي كما يلي .

$$
\text { هـ تح: هجري }
$$

د.ت : دون تاريخ

د.م : دون اسم مكان طبع 


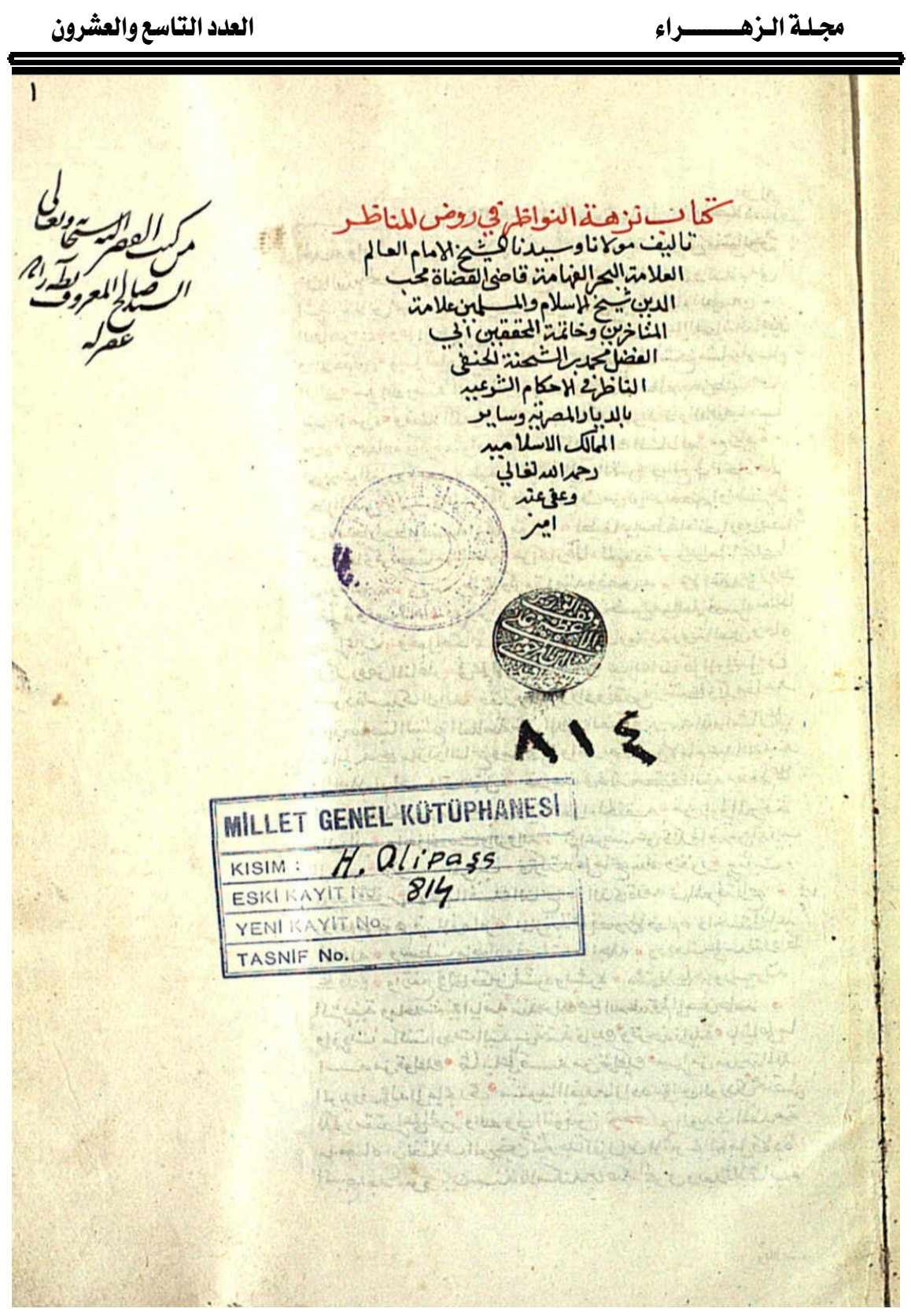

\section{بداية نسخة أ}




\section{بلاية الموضوع في نسخة أ}




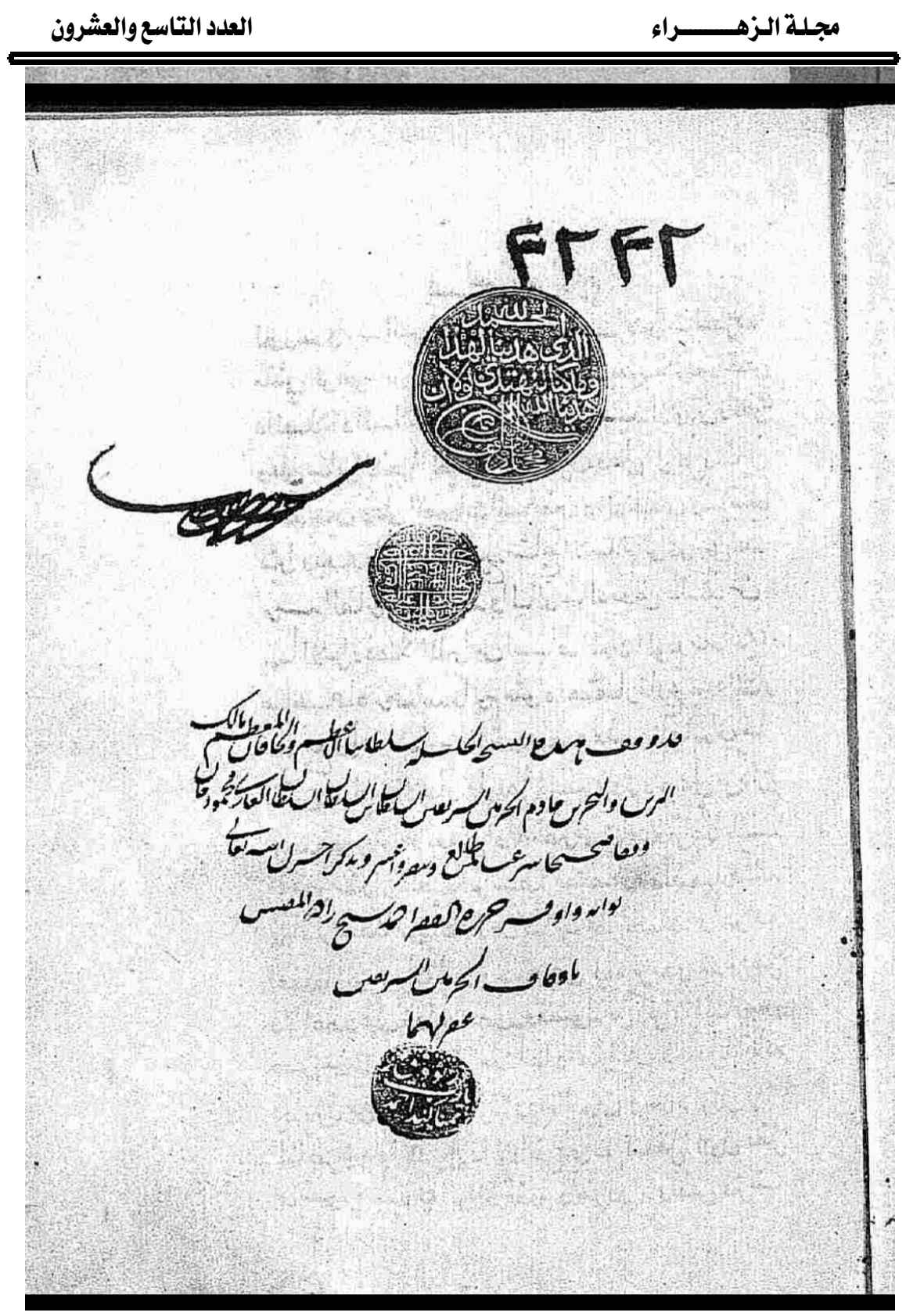

$$
\text { بداية نسخة ب }
$$


$\sigma$

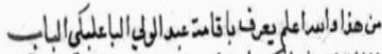

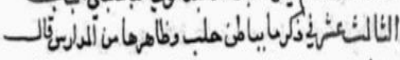

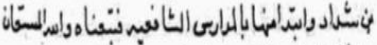

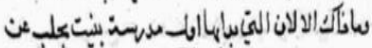

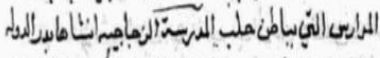

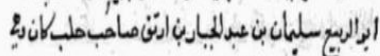

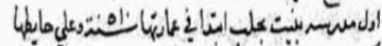

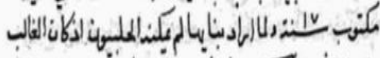

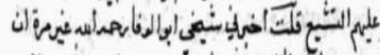

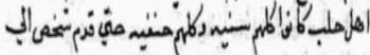

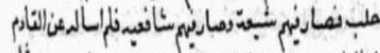

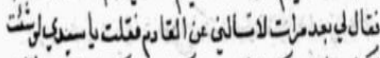

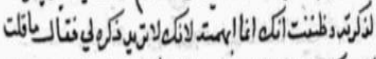

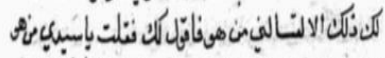

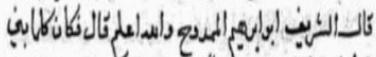

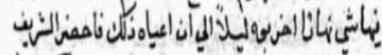

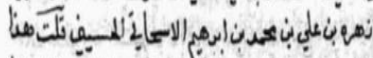

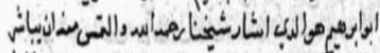

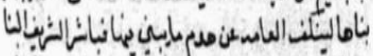

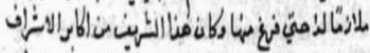

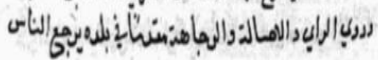

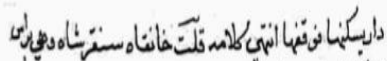

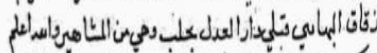

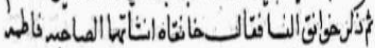

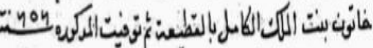

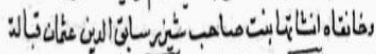

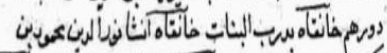

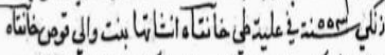

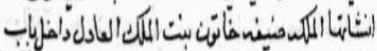

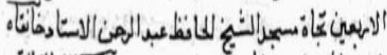

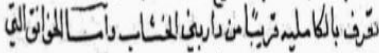

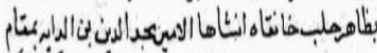

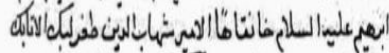

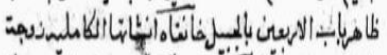

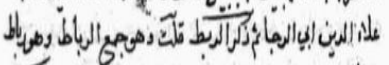

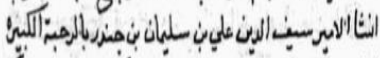

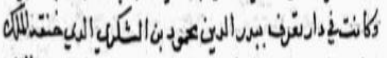

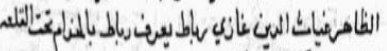

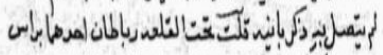

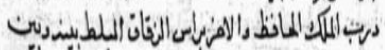

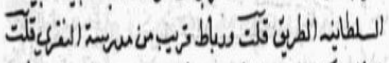

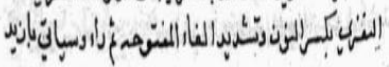

\section{بداية الموضوع في نسخة ب}


الباب الثالث عشر في ذكر ما بباطن حلب وظاهرها من المدارس

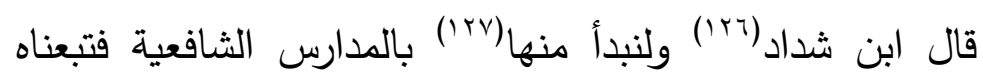

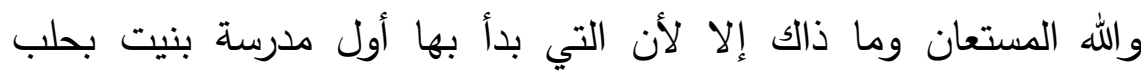

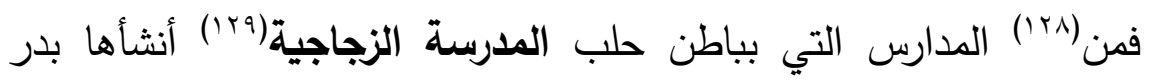

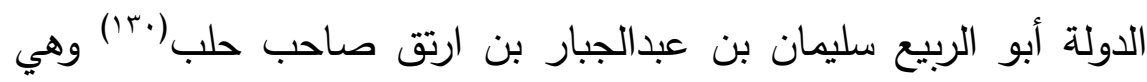

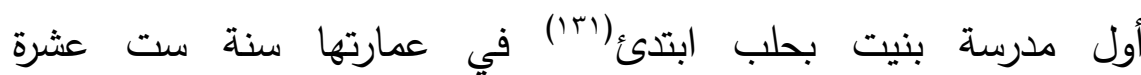

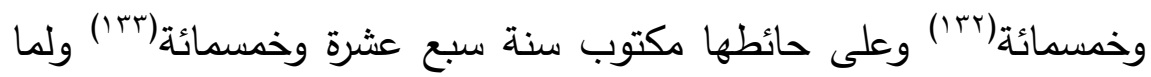

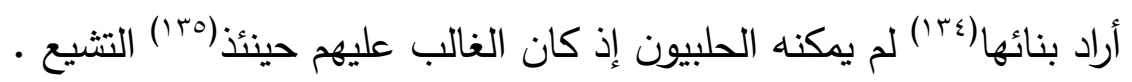

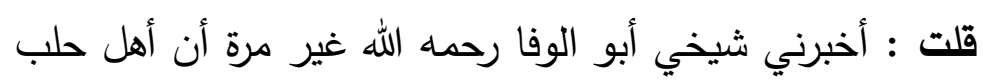

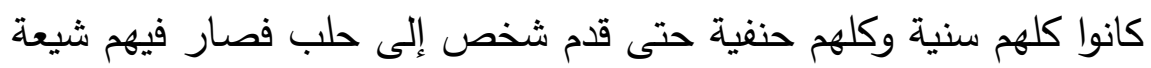
وصار فيهم شافعية فلم أسأله عن القادم ، فقال لي بعد مرات : ألا تسألني

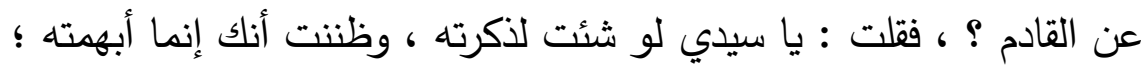

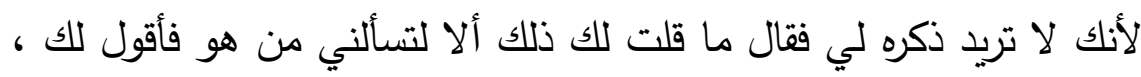

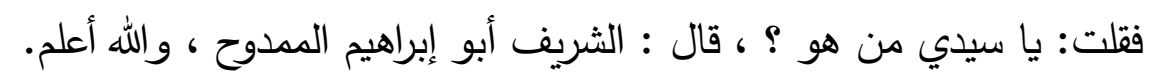

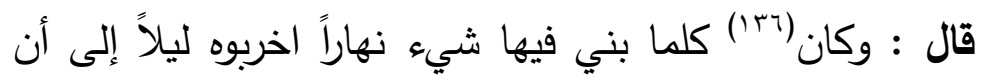
أعياه ذلك فأحضر الثريف زهرة بن علي بن حمحد بن أبي إبراهيم الإسحاقي

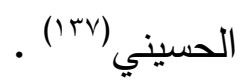

قلت ، (هذا هو أبو إبراهيم)(مrا1) الذي أشار شيخنا رحمه الله .

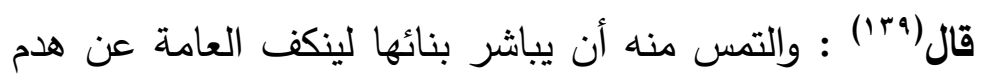

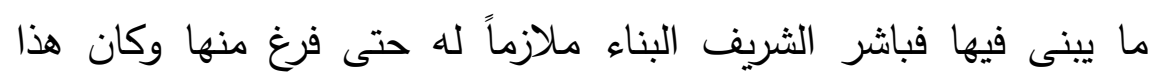
الثريف من أكابر الأشراف وذوي الراي والأصالة والوجاهة مقدماً في بلده لئه

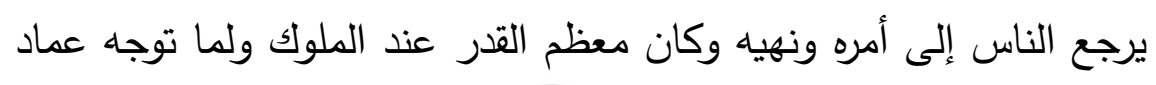


الدين زنكي إلى الموصل في سنة تسع وثلاثين وخمسمائة أخذه معه وأخذ

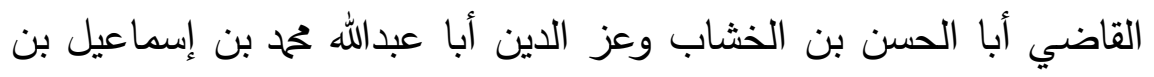

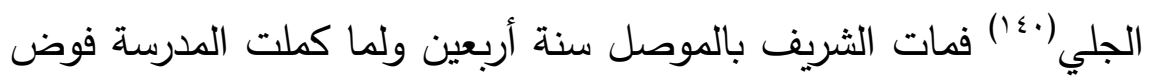

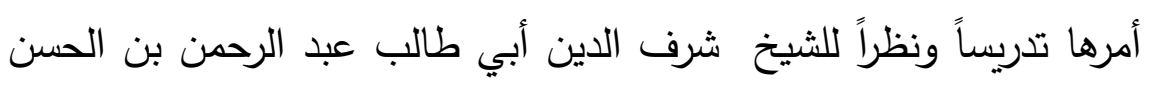

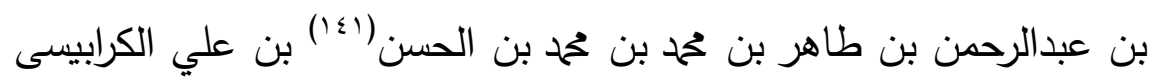

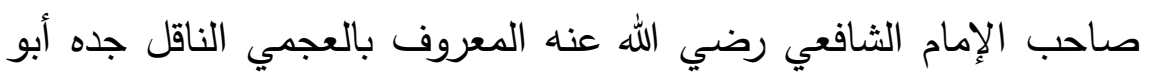

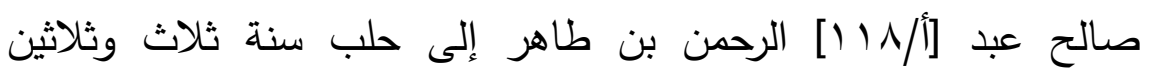
وأربعمائة، ولما ملك الأتابك عماد الدين زنكي بن قسيم الدولة اق سنقر

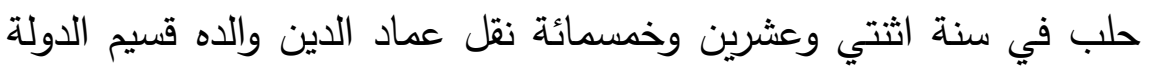

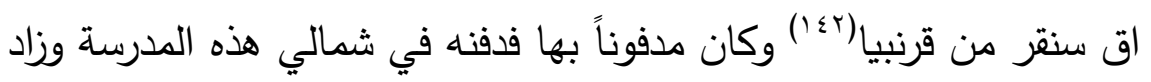

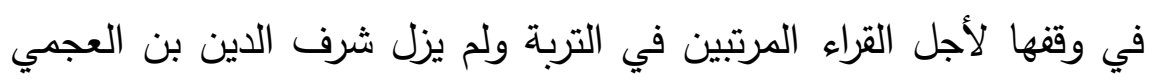

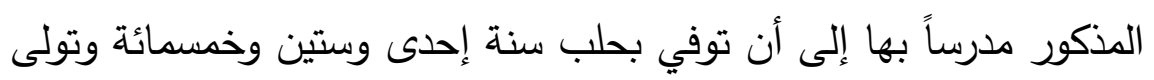

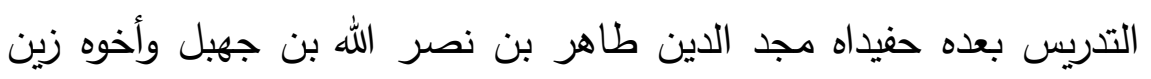

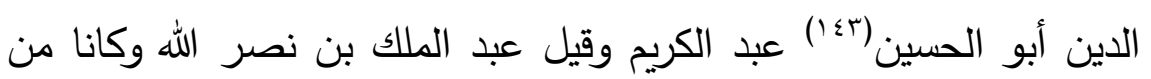
العلماء المتميزين والفضلاء المبرزين ولم يزالا بها مدرسين إلى أن أخرجها

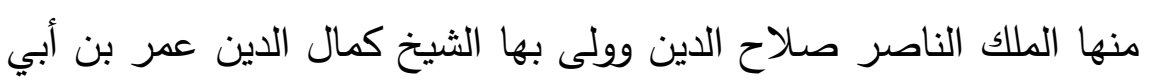

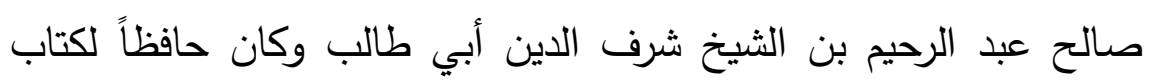

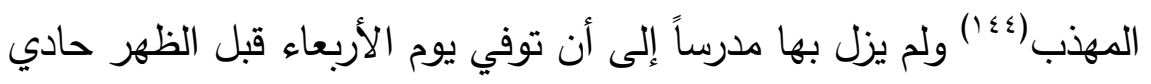

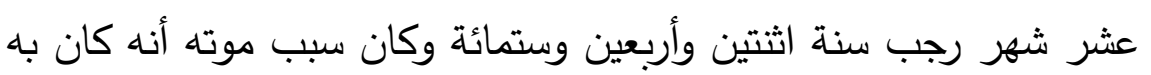

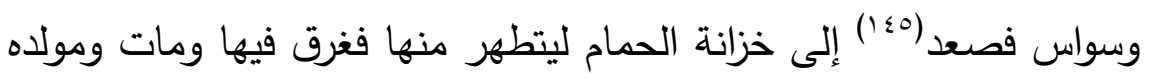

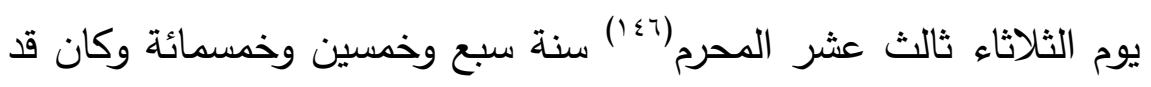
اشتغل بالفقه على ولدي عميه اللذين أخذ منهما المدرسة ثم وليها بعده ولدها

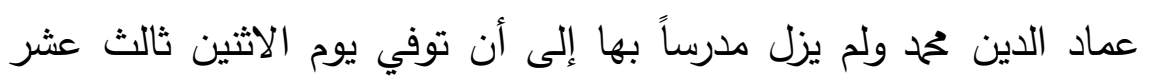


شعبان سنة تسع وأربعين وستمائة وكان مولده ليلة الخميس ثالث عشر

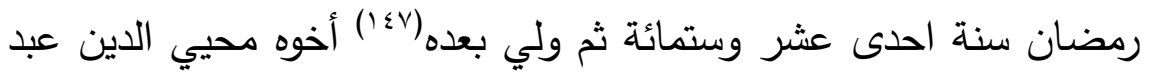
الله ولم يزل مدرساً بها إلى أن توفي في أواخر ذي القعدة سنة خمس وخمسين وستمائة وكان مولده رابع المحرم سنة تسع وستمائة ثم وليها بعده

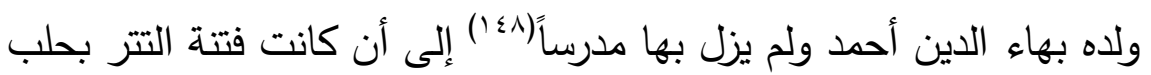

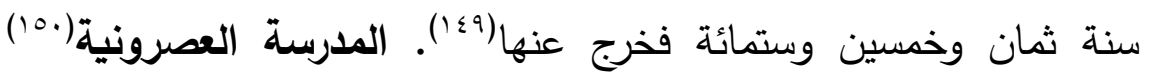
كانت داراً(101) لأبي الحسن علي بن أبي الثريا وزير بني مرداس(10r) فصيرها الملك العادل نور الدين محمود زنكي بعد انتقالها إليه بالوجه الشرعي مدرسة وجعل فيها مساكن للمرتبين بها من الفقهاء وذلك في سنة خمسين وخمسمائة واستدعي لها من جبل بناحية سنجار [الشيخ][(10\%) الإمام شرف الدين أبا سعيد(10) عبد الله بن أبي السري عحمد بن هبة الله بن بن الهن المطهر بن علي بن ابي عصرون بن ابي السري التميمي الحديثي ثم الموصلي الثافعي(100) وكان من اعيان فقهاء عصره وقرأ القرآن بالعشرة بن بن بري على أبي الغنائم السروجي والبارع إلى عبد الله محمد بن الدباس وأبي بكر بـاء المرزوقي وتفقه على القاضي المرتضى أبي ححم عبد الله بن القاسم

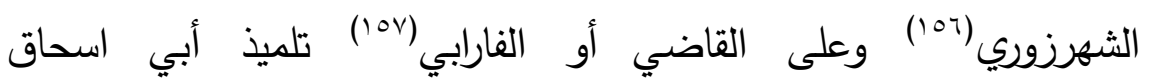
الفيروزآبادي(101) مصنف المهذب ولما وصل إلى حلب ولي تدريس المدرسة المذكورة والنظر فيها وهو أول من درس بها فعرفت به وصنف كتباً كثيرة في المذهب والخلاف والفرائض مشهورة في أيدي الناس وبنى له نور الدين محمود مدرسة بمنبج ومدرسة بحماة ومدرسة بحمص(109) ومدرسة ببعلبك ومدرسة بدمشق وفوض إليه أن يولي التدريس فيها من شاء ولم يزل متولياً أمر(·17) هذه المدرسة تدريساً ونظراً إلى أن خرج الى دمشت إنى سنة سبعين وخمس مائة(آI) وتوفي بدمشت ليلة الثلاثاء حادي عشر شهر (rآ) رمضان 
سنة خمس وثمانين وخمسمائة(1/) ولما خرج استخلف فيها ولده نجم الدين الاتي ذكره ولم يزل بها الى ان ولي قضاء [ب/1 1)] حماة فخرج عنها

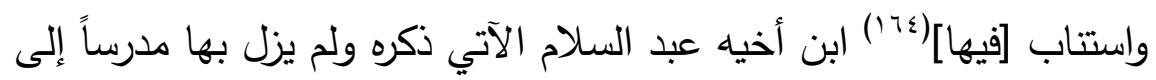
أن ورد على حلب ولده قاضي القضاة نجم الدين أبو البركات عبد الرحمن من حماة في أيام الملك الظاهر غياث الدين غازي سنة ثمان وتسعين وخمس مائة فولي تدريسها بنفسه ولم يزل بها مدرساً إلى أن رحل عن حلب إلى حماة فتوفي بها يوم الثلاثاء ثامن عشر شهر رمضان سنة اثنتين وعشرين وستمائة واستخلف فيها فخر الدين سُرخاب بن الحسن بن الحسين الأرموي(170) وكان ينوب عن والده الشيخ شرف الدين ولم يزل بها مدرساً نيابة واستقلالاً إلى أن خرج من حلب سنة خمس وستمائة يريد اربل فلما وفد وند ولند على الملك المعظم مظفر الدين كوكبري صاحب اربل فاكرمه واحتفل باه وكان يتردد اليه وأقام باربل إلى أن توفي في حادي عشر جمادي الأخرة سنة سبع وستمائة ، وتولى تدريسا بعد خروجه من حلب الثيخ شهاب الدين عبد السلام بن المطهر بن الثيخ شرف الدين أبي سعيد عبد الله بن

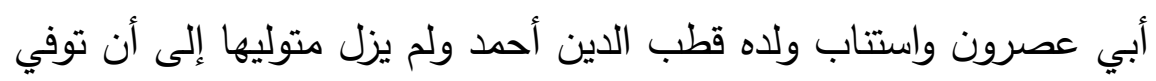
بدمشق في الثامن والعشرين من المحرم سنة اثثتين وثلاثين وستمائة ، ثم ولها بعده ولده قطب الدين أحمد وعز الدين عبد العزيز بن نجم الدين عبد الرحمن بن شرف الدين ولم يزالا بها إلى أن وقعت لهما واقعة بحلب فصرفوهما منها وحبسا ثم أخرجا من حلب سنة ست وثلاثين وستمائة فقصد قطب الدين(Trا) دمشت فأقام بها وقصد عبد العزيز مصر واتصل بالملك

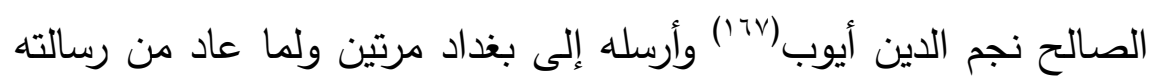
في المرة الثانية توفي بالقدس في شهر رمضان أو شوال سنة ثلاث وأربعين وستمائة وتولى تدريها بعده شرف الدين عثمان بن ححمد بن أبي عصرون 
المعروف بالتركي(171) مدة ثم رحل(179) إلى دمشق وتولاها نجم الدين احدد

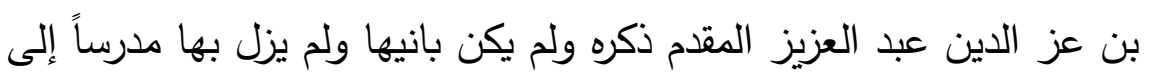

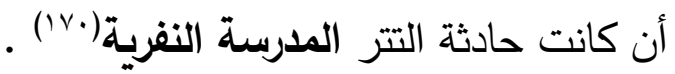
والنفرية : بكسر (IVI) النون ، وفتح الفاء المشددة ، وكسر الراء لا أدري من المنسوبة إليه هذه المدرسة ، ولكن من يقال له النفري جماعة

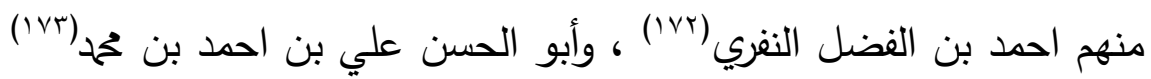

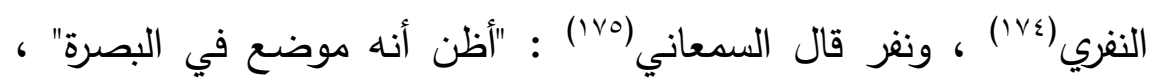
وقيل : هو بلد على النرس(r/V) بفتح النون وسكون الراء وآخره سين مهملتين

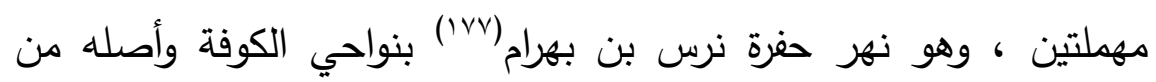

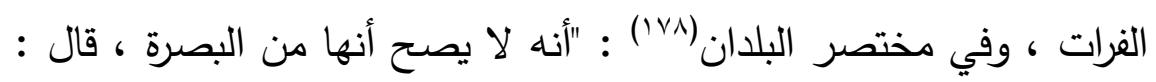

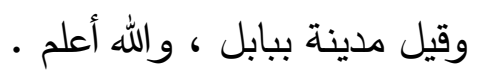

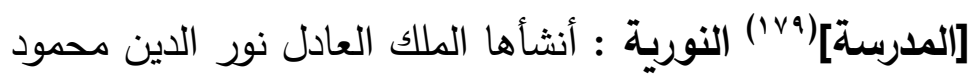
بن زنكي في سنة اربع واربعين وخمسمائة وأول من ولي التدريس بها قطب

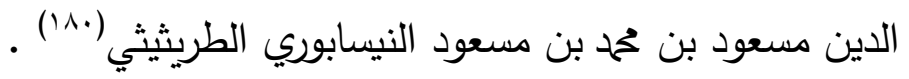
قلت : والطرثيثي بضم الطاء وفتح الراء ثم تحتانية ساكنة ثم بـ

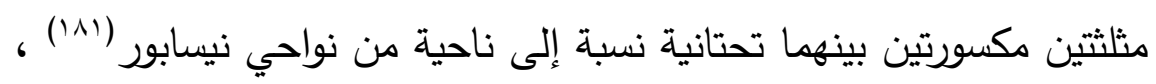
والله أعلم ملفين مصنف كتاب الهادي في الفقه والتزم فيه أن لا يأتي إلا بالقول الذي عليه الفتيا ، وكان اشتغال قطب الدين هذا بنيسابور ومرو سمع

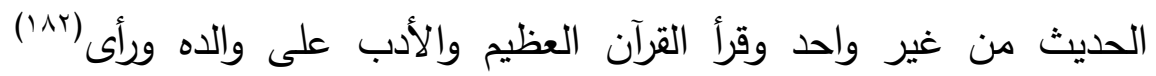

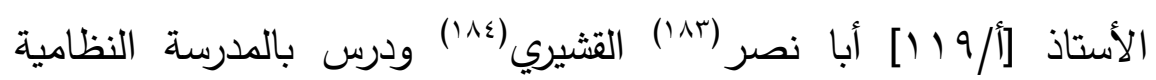
بنيسابور نيابة عن ابن الجويني(100) وقدم دمشق سنة أربعين وخمسمائة ووعظ بها وأقبل الناس عليه ودرس بالمدرسة المجاهدية(1/1) المنسوبة ولية 
لمجاهد الدين بزان بن مامين(INV) صاحب صرخد [بياض في المسودة] ثم بالزاوية الغربية من جامع دمشق(^^) بعد موت الفقيه ابي الفتح نصر الله

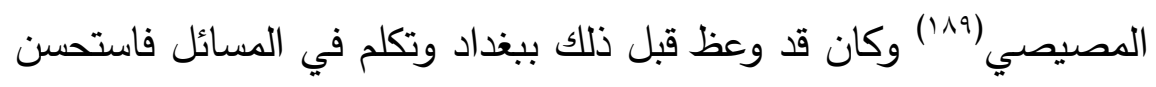
ثم رحل عن دمشق إلى حلب فولي تدري المدرسة المذكورة وولي تدري المدرسة الأسدية التي بالرحبة على ما يأتي ثم مضى إلى همدان ، وتولى لى لهى التدريس بها ثم عاد إلى دمشق ودرس بالزاوية التي كان(.9.") يدرس بها أولاً

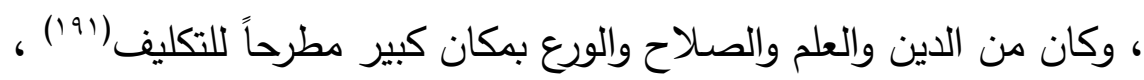
ولد سنة خمس وخمسمائة ثالث عشر رجب ، ودن وتوفي آخر يوم من شهر رضنان سنة ثمان وسبعين وخمسمائة ، وصلى عليه غد نهار الجمعة يوم العيد ، ودفن في مقبرته التي أنثأها جوار مقابر الصوفية غربي دمشق ، ثمدين

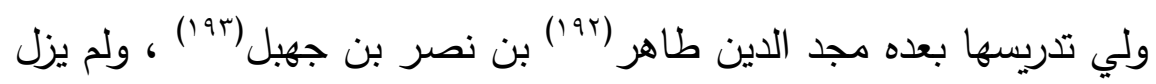
مدرساً بها إلى أن انتقل إلى القدس الشريف ، وتوفي بهدي بها سنة سبع تسعين وخمسمائة وبعد ما نقل المذكور تولى تدريسها القاضي ضياء الدين أبو

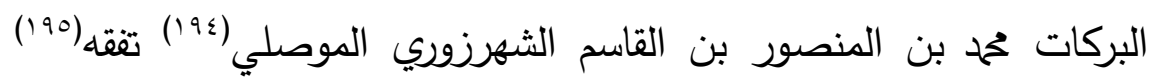

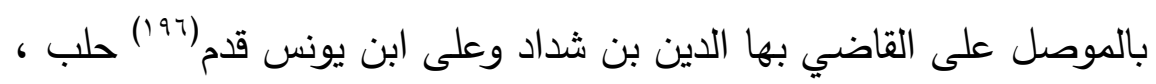
وتولى نيابة الحكم بها عن القاضي بهاء الدين بن شداد ، ولم يزل مدرساً بها إلى أن توفي في الثاني من شعبان سنة احدى وستمائة ، فولى تدريسها

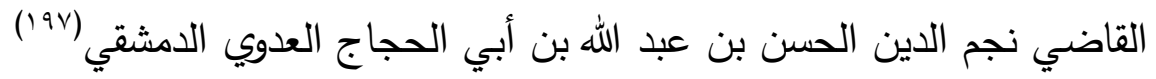

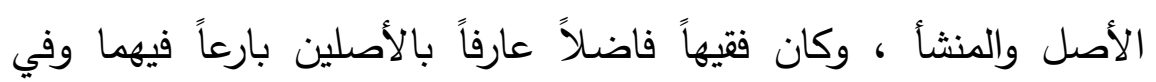

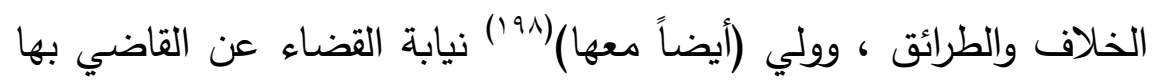

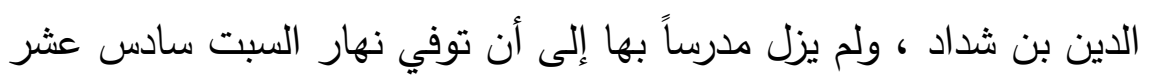
شهر ربيع الأول ، ودفن نهار الأحد سابع عشر سنة ثلاث وعشرين وستمائة ، فولى تدريها بعد صدر الدين تحمد بن [بياض في النسختين] 
الكردي الكاجكي(199) قاضي منبج ولم يزل مدرساً بها إلى أن سافر

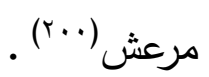

قلت : مرعش بفتح الميم ، وسكون الراء ، وفتح العين المهملة ،

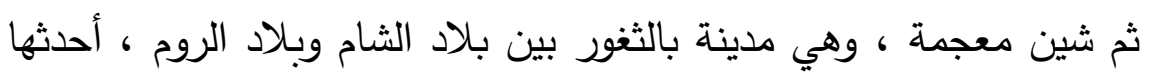
الرشيد(ب+r) لها سوران ، وفي وسطها حصن يسمى المرواني ، بناه مروان

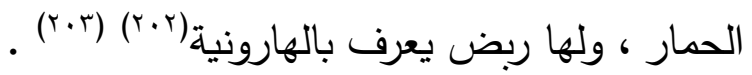

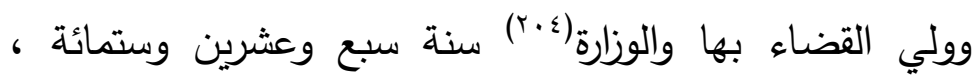
وتوفي بمرع ، فولي تدريسها الثيخ الإمام عماد الدين أبو المحاسن

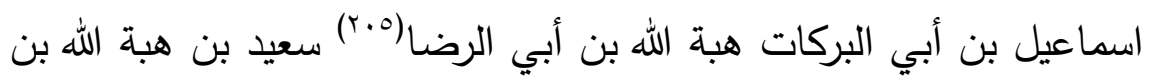

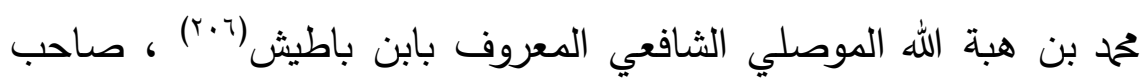

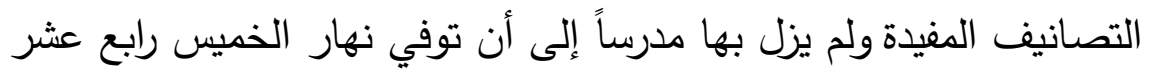

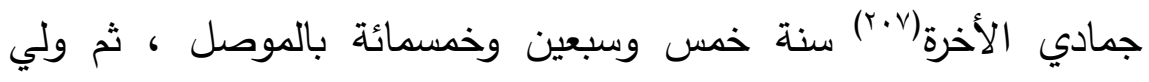
تدريسها الشيخ زين الدين عبد الملك بن الثيخ شرف الدين أبي حامد عبد الله بن الشيخ شرف الدين أبي طالب عبد الرحمن بن العجمي(^•r) في سنة

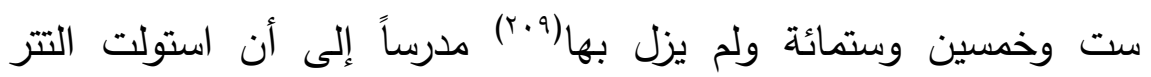
على(·r) حلب واستمر بها بعد ذلك إلى أن خرج من حلب المداته المدرسة الصاحبية أنثأها القاضي بهاء الدين أبو المحاسن يوسف بن رافع بن تميم المعروف بابن [ب/9 1 1 ] شداد رحمه الله في سنة احدى وستمائة ، ودرس بها واستناب القاضي زين الدين أبا محه عبد الله بن الشيخ الحافظ عبد الرحمن بن علوان الأسدي(I'I') رحمه الله ، ولما توفي القاضي بهاء الدين سنة اثتين وثلاثين وستمائة ، ولي زين الدين القضاء ودرس بالمدرسة استقلالاً ، ولم يزل بها إلى أن توفي سنة خمس وثلاثين ، فوليها ولده

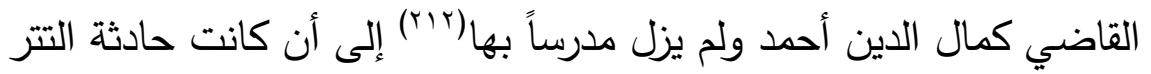


، فخرج عنها إلى ديار مصر ثم عاد إلى حلب في أواخر سنة احدى وستين وستمائة ، وولي تدريس مدرسة القاضي بهاء الدين بن شداد(rاب( ) .

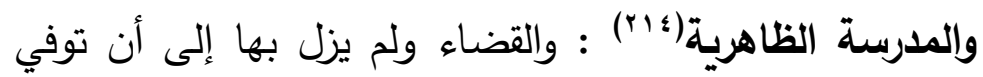
في ليلة الأحد رابع وقيل خامس عشر شوال من سنة اثنتين وستين وستمائة ، وولي تدريسها بعده القاضي محيي الدين أبو المكارم محمد بن قاضي

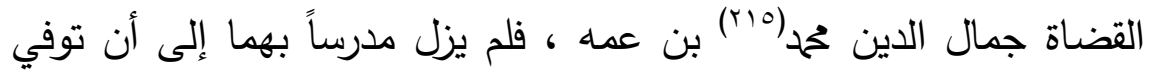
سنة تسع وستين ، ووليها أخوه افتخار الدين عثمان فلم يزل مدرساً بالصاحبية فقط إلى أن توفي بالديار المصرية ، وولها ولده شرف الدين عبد ولدين المجيد مع الأوقاف بحلب ، وهو مستمر بها إلى تاريخ سنة سبع وسبعين

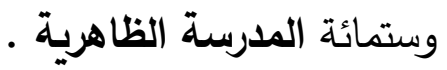
قلت : وهي المعروفة الآن (T/Y) بالسلطانية ، والله أعلم •

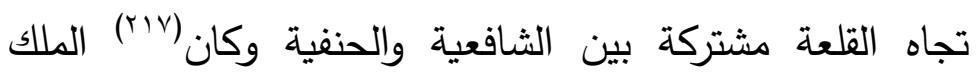
الظاهر قد أسسها وتوفي في سنة ثلاث عشرة وستمائة ، ولم تتم وبقيت مدة بعد وفاته حتى شرع شهاب الدين(^/^) طغربل اتابك الملك العزيز فيها فعمروها(Y) وكملها سنة عشرين وستمائة ، ودرس فيها القاضي بها الدين

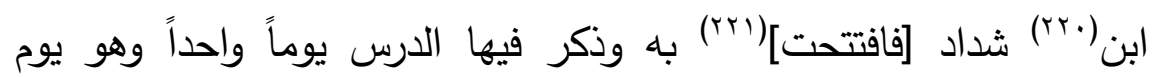
السبت ثامن عشر شعبان من السنة المذكورة ، وولي نظرها فولاها القاضي زين الدين أبا ححم عبد الله الأسدي قاضي القضاة بحلب . فلم يزل مدرساً بها إلى أن توفي في سنة خمس وثلاثين وستمائة ، وكان يدرس بها المذهبين ، فوليها بعده ولده القاضي كمال الدين أبو بكر لئ أحمد(rrr) ولم يزل مدرساً بها إلى استيلاء التتر على حلب ، وكان ، وكان أيضاً

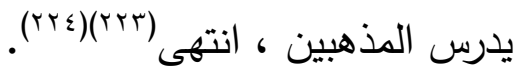


قلت : منقوش على بابها أنها وقف على الطائفتين الشافعية والحنفية وإن الواقف شرط(roro) أن يكون الإمام فيها والمدرس بها شافعي المذهب لكن كان سيدي الوالد تغده الله برحمته مدرساً بها للحنفية ، ورأيت

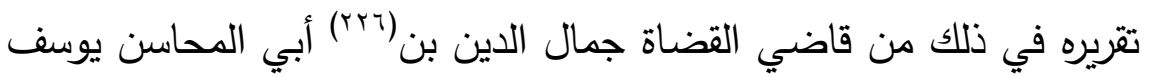
الحثفاني(r.V) ، ووليته بعد موت والدي ثم إن قاضي القضاة علاء الدين بعد أن تزوجت ابنته حضر إلي وسألني في التقرير المذكور فأعطيته إياه وتركت التدريس بها لأجل خاطره ، والله أعلم .

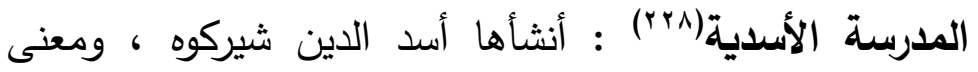

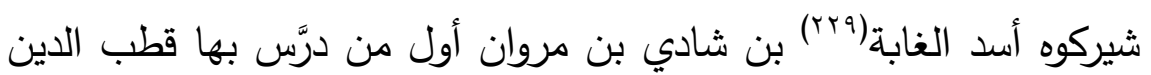
مسعود بن محمد بن مسعود المقدم ذكره في تدريس المدرسة النفرية ثم تولاها شمس الدين أبو المظفر حامد بن أبي العميد عمر بن أمري(r.ror) بن ورشي القزويني (ا⿳r厂) ولم يزل بها إلى أن رحل من حلب إلى إلى إنى مدينة حمص سنة ستمائة ، فوليها بعده الثيخ شمس الدين(بr)

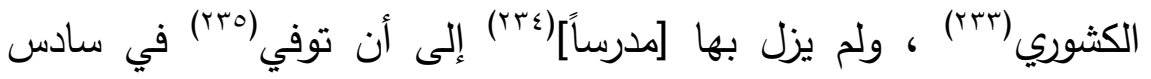
عشر ربيع الأول سنة ثمان وستمائة ، ووليها تقي الدين أبو عمرو عثمان

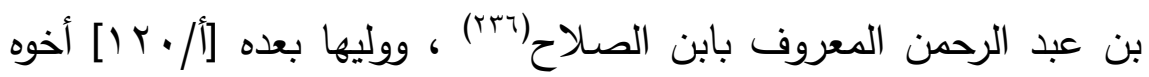
سديد الدين ابراهيم ثم رحلا [بياض في المسودتين ] ووليها بعد سديد الدين(rrrr) ولده [بياض في الأصل] وولى تدريسها بعده الفقيه صلاح الدين

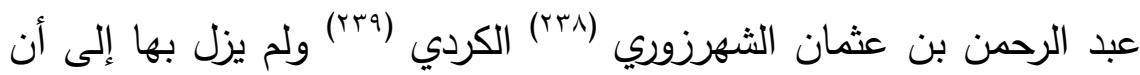
توفي ليلة الخميس ثامن عشر ذي الحجة سنة ثمان عشرة وستمائة ثم وليها شرف الدين حمح بن عبد الرحمن المعروف بابن الصلاح ولم يزل بها إلى أن توفي بالاستسقاء ثم وليها معين الدين [بياض في الأصل] ابن المنصور بن القسم الثهرزوري مدة شهر واحد ثم رحل إلى حمص ووليها نجم الدين ححم 


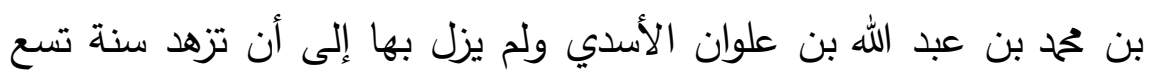

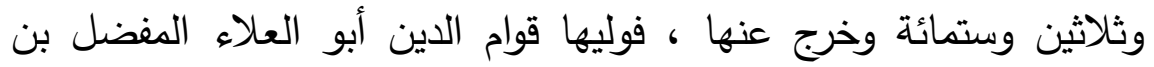

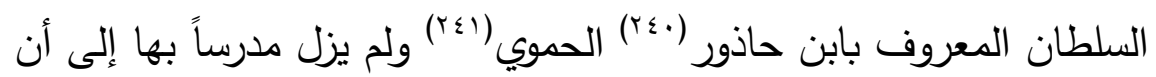

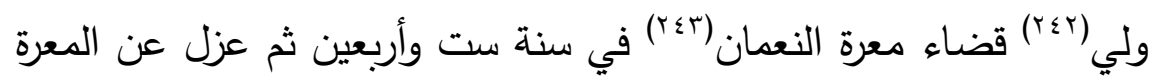

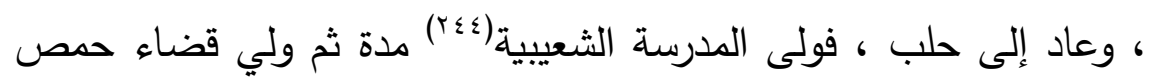
سنة خمس وخمسين وستمائة ثم عزل عن حمص ، وتوفي سنة ستين

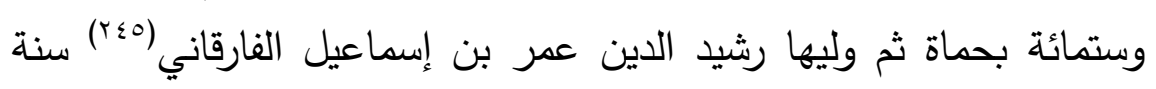

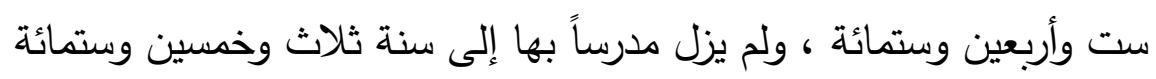

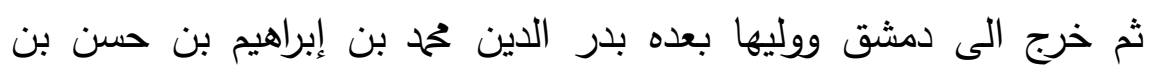

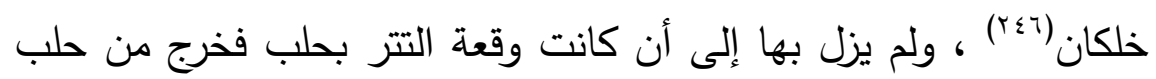

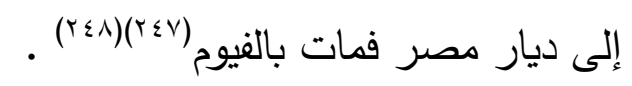

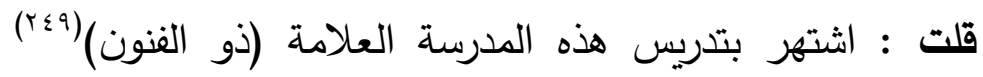

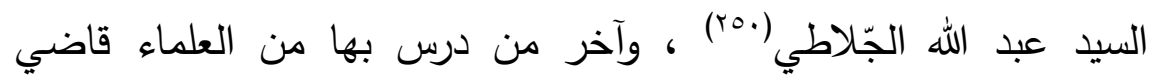

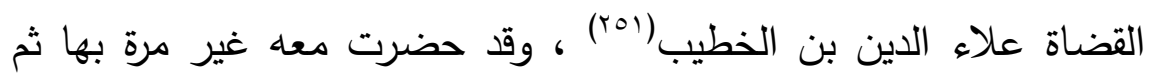
تلاشى الحال بعد موته ، وهي الآن متلاشية كغيرها ، والله المستعان . 
المدرسة الرواحية(ror) : أنثأها زكي)(ror) الدين أبو القاسم هبة

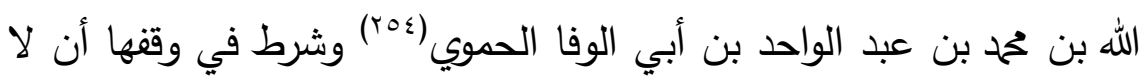
يتولاها(ro0) حاكم متصرف [بياض في الأصل] ثم وليها القاضي زين الدين أبو عحم عبد الله بن الثيخ الحافظ عبد الرحمن بن عبد الله بن علوان الأسدي ولم يزل مدرساً بها إلى أن ولي نيابة الحكم بحلب سنة ثلاث وعشرين(ror)، فدرس فيها أخوه القاضي جمال الدين أبو عبد الله خحم ولم يزل بها إلى سنة اثنتين وثلاثين فتولى نيابة الحكم بحلب عن أخيه قاضي القضاة زين الدين أبي تحمد عبد الله فتولى التدريس بها ابن أخيه بهاء الدين يوسف بن قاضي القضاة زين الدين (rov) ولم يزل بها إلى أن توفي في أوائل سنة خمس وثلاثين فوليها بعده الثيخ الإمام نجم الدين أبو عبد الله

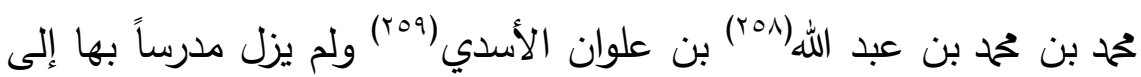
أن تزهد سنة تسع وثلاثين ، فخرج عنها ، ثم وليها بهاء الدين الكردي ولم يزل بها إلى أن توفي ، ووليها القاضي محي الدين تحمد بن القاضي جمال

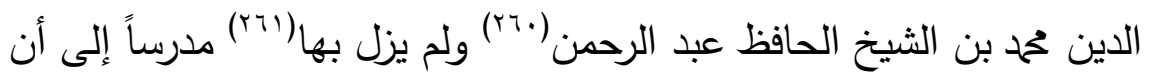
تولى نيابة الحكم بحلب ثالث عشر رمضان سنة أربع وأربعين وستمائة فتولى تدريسها كمال الدين أبو الفضل أحمد بن القاضي نجم الدين الحسن بن عبد الله بن الحجاج الكردي(זrr) ولم يزل بها إلى أن توفي يوم الخميس تاسع عشر جمادي الآخرة(بآ) سنة خمس وأربعين وستمائة ، ووليها بعده الثيخ مجد الدين محمد بن هدية بن محمود [بياض في الأصل] الأشنهي ولم يزل بها إلى أن توفي سنة ست وخمسين وستمائة ، ووليها بعده عماد الدين

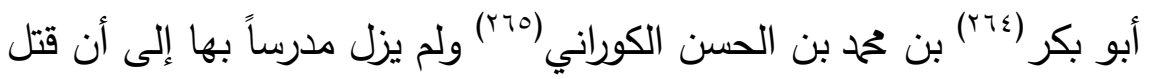
في وقعة التتر بحلب(rrr) .

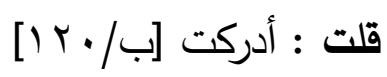


من كان قاضياً وهو مدرس بها فلا أدري اخفى عليه شرط الواقف أو أن المؤلف سمع ذلك من غير وقوف عليه ، والله أعلم • المدرسة الثعيبية(YYYY) : كانت هذه المدرسة مسجداً وقد تقدم ذلك مستوفئ فلما ملك نور الدين حلب وأنشأ المدارس بها وصل الشيخ شعيب

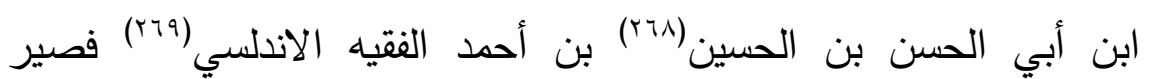
له(Y.) هذا المسجد مدرسة فعرفت به ولم يزل مدرساً بها إلى أن توفي سنة ست وتسعين وخمسمائة في طريق مكة ودفن بين تيماء(اYY) وحفر بني عنزه وكان من الفقهاء المعتبرين والزهاد المعروفين وكان من أصحاب الحافظ وحئ ودئ

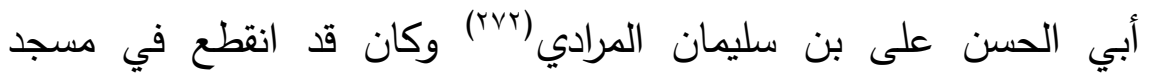
الغضائري فعرف المسجد به وانقطع عنه اسم الغضائري ثم وليها بعد الثيخ شمس الدين حمح ابن موسى الجزري ولم يزل بها إلى أن توفي في سنة ثلاث وثلاثين وستمائة ثم وليها موفق الدين أبو القاسم بن عمر بن فضل

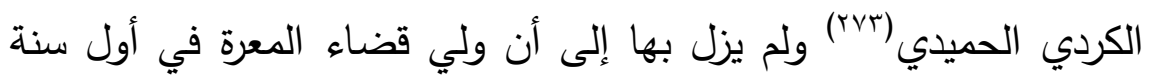
اثنتين وأربعين وستمائة فوليها بعده قوام الدين أبو العلا المفضل بن سلطان

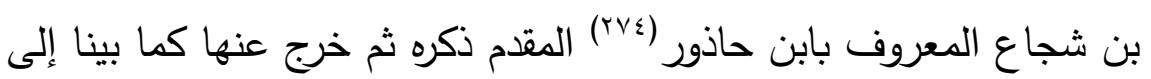
حمص سنة خمس وخمسين فوليها بدر الدين حمح بن إبراهيم بن خلكان المعروف بقاضي (تل باشر)(rVO) المقدم ذكره •

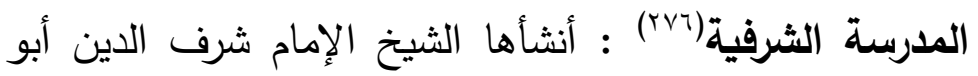
طالب عبد الرحمن بن أبي صالح عبد الرحيم المعروف بابن العجمي(YYY) وانصرف(YVA) عليها ما ينيف على أربع مائة الف درهم ووقف عليها أوقافاً جليلة ودرس فيها ولده محيي الدين تحمد وأعاد لله فيها عشرة أنفس لم يكن في عصرهم في سائر البلاد مثلهم ولم يدرس فيها غيره الى ان قتل شهيداً بأيدي التتر بعد استيلائهم على حلب وأما الثيخ شرف الدين الواقف المذكور فإنه 
توفي بعد استيلاء التتر على حلب في رابع عشر صفر سنة ثمان وخمسين

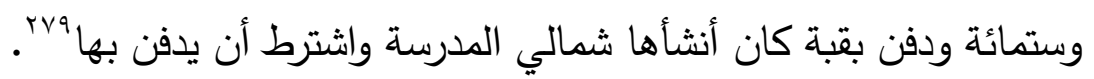

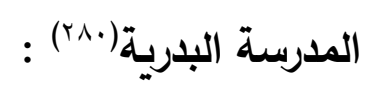

أنشأها بدر الدين(ب/(Y) بدر عتيق عماد الدين شادي بن الملك

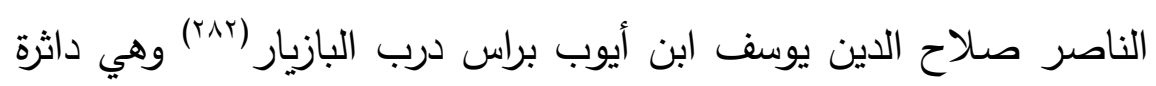
- الآن

المدرسة الزيدية(r/r) : أنشأها إبراهيم بن إبراهيم المعروف بابن

زيد الكيال الحلبي(ع^^) انتهت سنة خمس وخمسين وستمائة ودّرس فيها

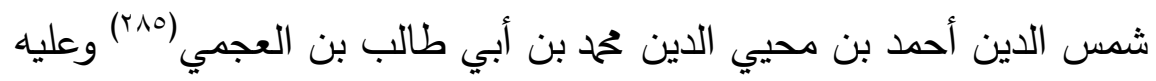
انقضت الدولة .

المدرسة السيفية(T^r) : أنثأها الأمير سيف الدين علي بن علم الدين سليمان بن جندر (YAY) (YAN) انتهت لسنة سبع عشر وستمائة [مشتركة

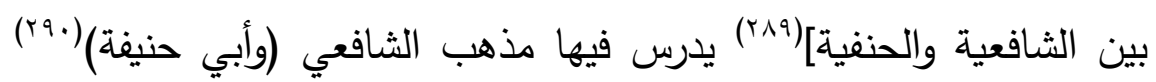
وأول من درس بها مذهب الإمام الثافعي القاضي بهاء الدين أبو المحاسن يوسف بن رافع بن تميم المعروف بابن شداد(اوr) ولم يزل بها مدرساً قريباً

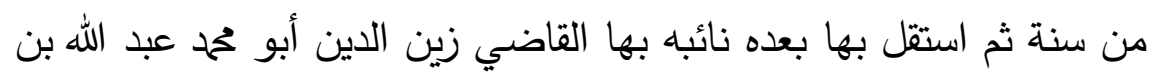

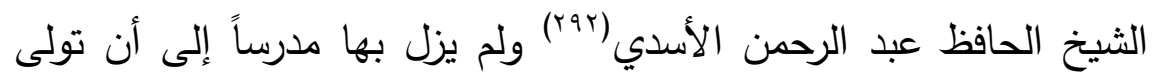
نيابة الحكم للقاضي (rar) بها الدين سنة ثلاث وعشرين فوليها نجم الدين أبو

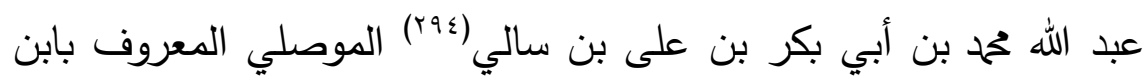

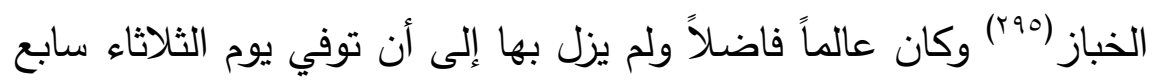
ذي الحجة سنة احدى وثلاثين وستمائة فوليها القاضي جمال الدين أبو عبد

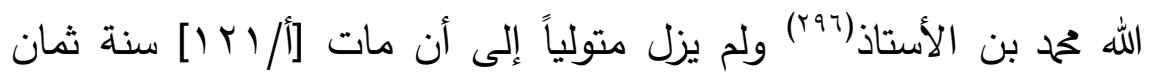




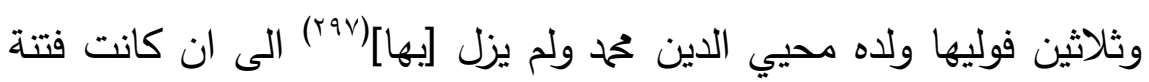

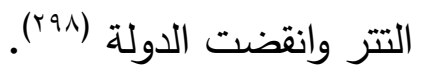

ثم ذكر (997) المدارس الثافعية التي بظاهر حلب فقال : المدرسة

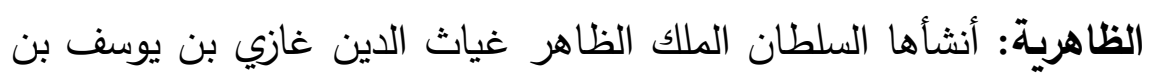

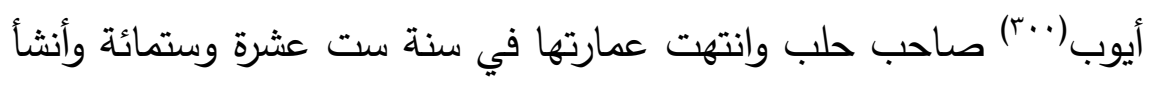

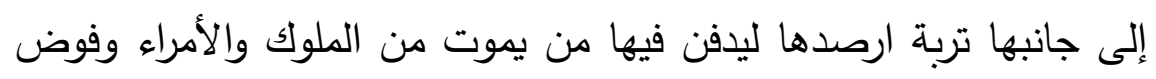

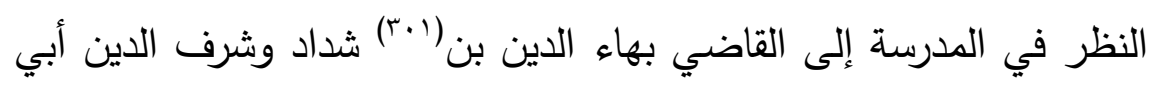

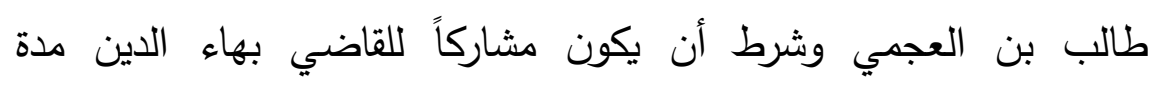

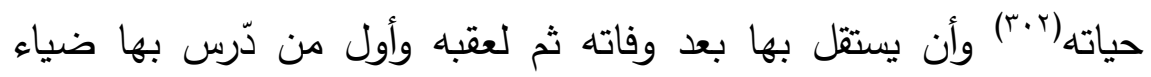

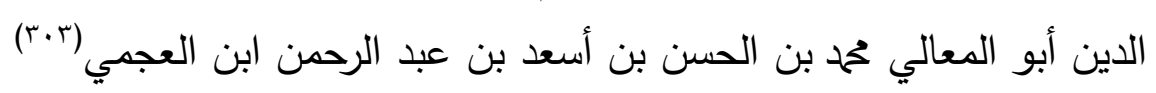
وحضر يوم تدريسه الملك الظاهر بنفسه وعمل دعوة عظيمة حضرها

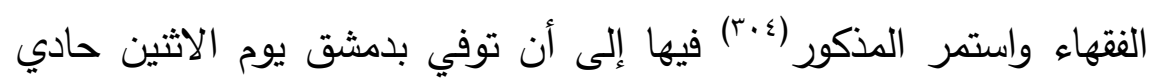
عشر (r.0) صفر عند عودته من الحجاز سنة خمس وعشرين وكان مولده

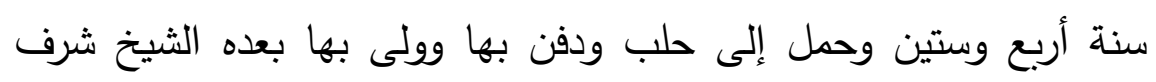
الدين أبو طالب بن (َ.r) العجمي ولم يزل بها مدرساً إلى سنة الثنتين وأربعين

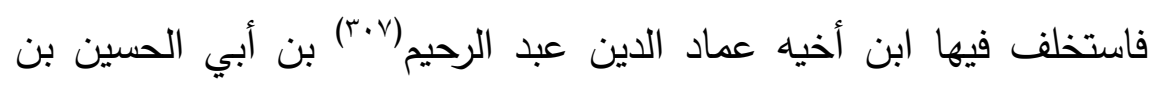

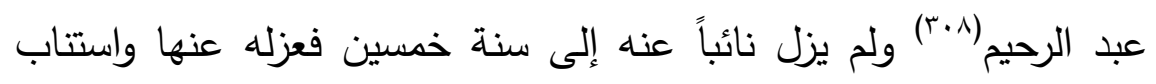

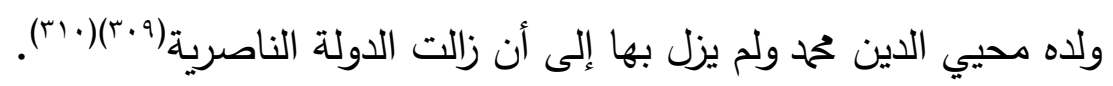

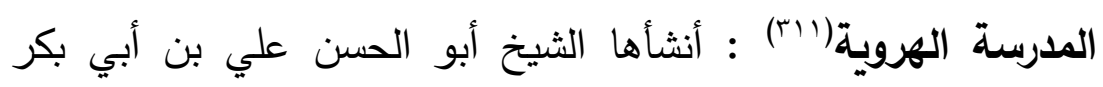

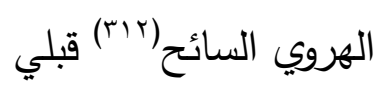

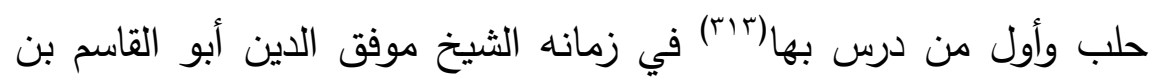

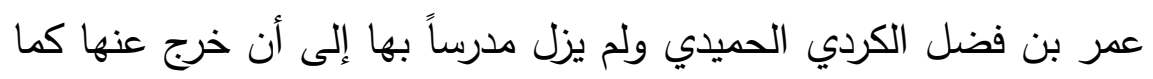

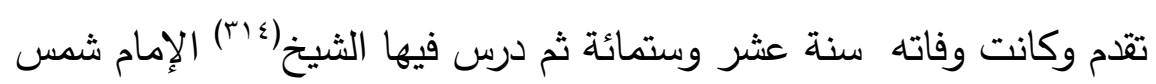


الدين أبو المظفر حامد بن أبي العميد بن أميري بن ورشي القزويني(r/o)

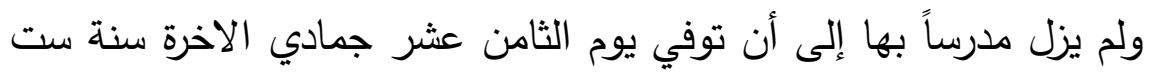
وثلاثين وستمائة وكان مولده سنة سبع واربعين وخمسمائة ووليها بعده ولده

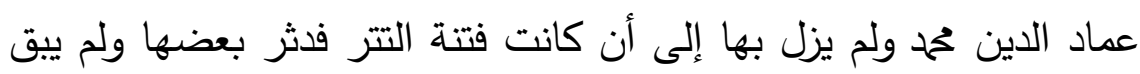

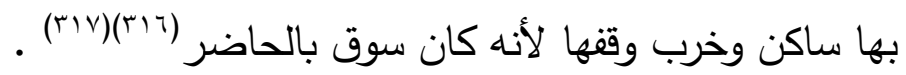

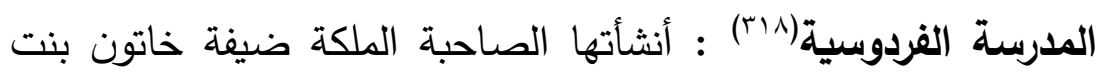
الملك العادل سيف الدين أبي بكر محمد بن أيوب وهي جليلة كبيرة

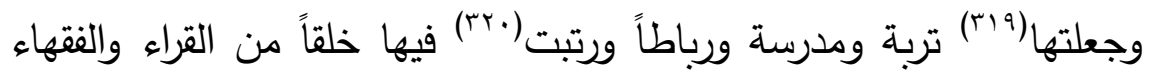

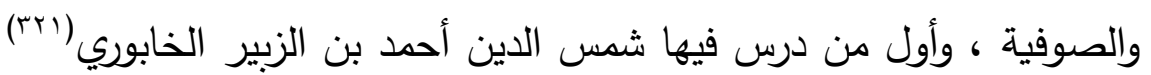

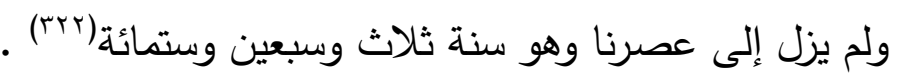
قلت : أدركناها ، وقضاة حلب يكون نظرها وتدريسها ولم يزالوا يتداولونها إلى زمن الملك الظاهر (rrT) جقمق( ابن أبي رحمه وكان في نفس الظاهر شيء من ابن خطيب الناصرية ففوضها إلى ابن أبي رحمة المذكور ثم توجه لما ابن الخطيب الناصرية إلى هـ القاهرة استعادها فحشد ابن أبي رحمة جماعة من العرضيين ووقف بدار العدل فلم يلتفت النائب الى ذلك ثم مرض ابن الخطيب الناصرية مرض الموت فاشتغل بنفسه إلى أن توفي إلى رحمة الله تعالى والأمر موقوف ، و الله أعلم المدرسة البلدقية(rrr) [ب/ ا I I] : أنثأها الأمير حسام الدين بلدق عتيق الملك الظاهر وكان من أعيان الأمراء وأول من درس بها ركن الدين جبريل بن محمد بن عكاوية التركماني(rrV) وتوفي بها ودرس فيها بعده ولده عز الدين أحمد ولم يزل بهاء

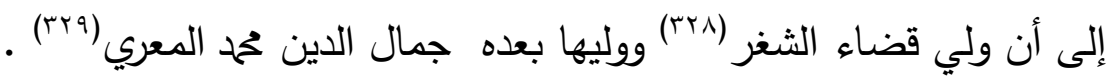


المدرسة القيمرية(·rr) : أنشأها الأمير حسام الدين الحسن بن أبي الفوارس القيمري(ابr) في مجاورة المقام سنة ست وأربعين وأول من دّرس بها ركن الدين جبريل المقدم ذكره جامعا بينها وبين البلدقية وتوفي بها ودرس فيها بعده ولده عز الدين احمد ولم يزل بها إلى ان ولى قضاء الثغر ووليها

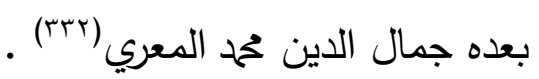
مدرسة بالجبيل(rrr) : أنشأها شمس الدين أبو بكر أحمد بن أبي صالح

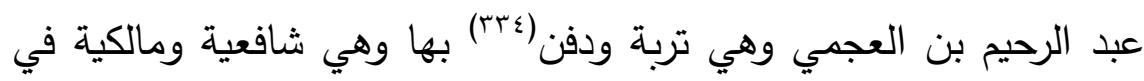
سنة خمس وتسعين وخمسمائة والمدرس (ror) بها أخوه الثيخ شرف وفي الدين

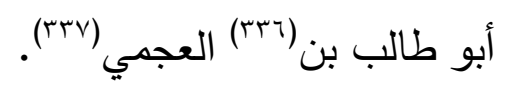

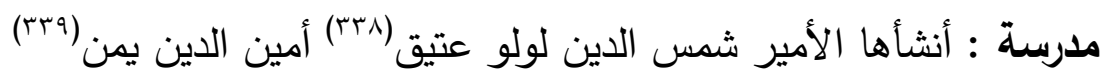
عتيق نور الدين ارسلان بن مسعود صاحب الموصل أول من درس بها(•؟r) الشريف عبد الله الحسيني ولم يزل بها مدرساً إلى أن توفي سنة اثنتين وخمسين وستمائة وولها بعده شرف الدين عبد الرحمن بن عثمان بن خحم

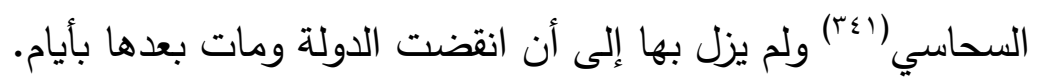

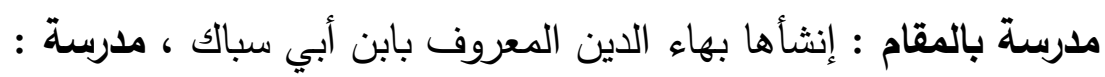

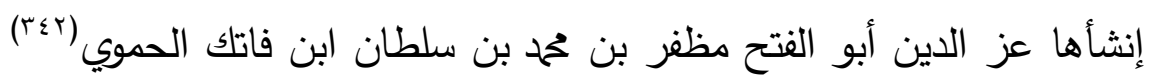

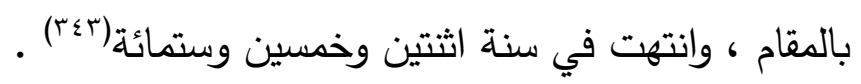




\section{قائمة المصادر :}

- ابـن الاثير ، ابو الحسن علي بن ابي الكرم كحمد بن عبد الكريخ

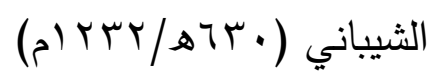

- الكامل في التاريخ ، تـح : عمر عبد السـلام تدمري ، طا ، دار

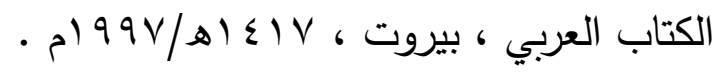

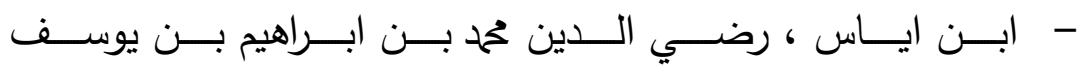

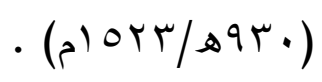

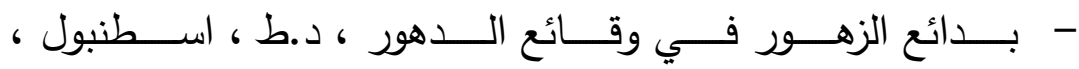

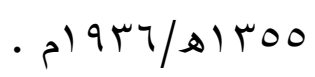

- البيروتي ، محمد ابو اليمن بن عبد الرحمن بن عحمد بن عبد السـلام

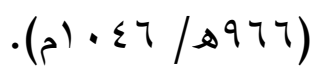

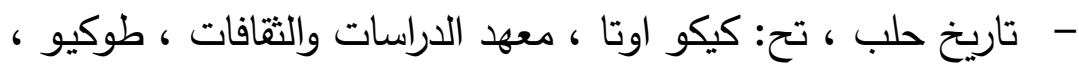

$$
\text { . } 199 \cdot / 81 \leq 11
$$

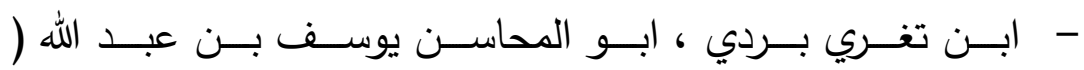

$$
\text { - (م) } \leqslant 79 / ه \wedge \vee \leqslant
$$

- - المنهل الصـافي والمستوفي بعد الوافي ، تح: تحمد محمد امين ،د.ط ،

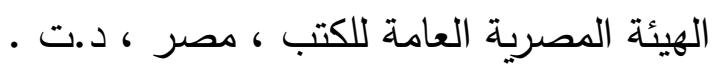
- - النجوم الزاهرة في ملوك مصـر والقـاهرة ، وزارة الاوقاف والارشـاد

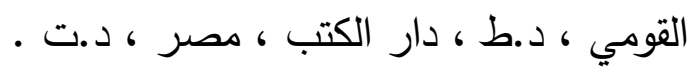
- ابن الجوزي ، جمال الدين ابي الفرج عبد الرحمن بن علي بن محمد (

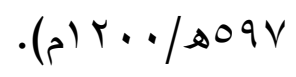




\section{ذكر ما بباطن حلب وظاهرها من المدارس "المدارس الشافمية””}

- المنتظم في تـاريخ الامـم والملـوك ، تـح : عحم عبد القـادر عطـا ومصطفى عبد القادر عطا ، طاه، دار الكتب العلمية ، بيروت ،

$$
\text { - } 994 / 81 \leq 14
$$

- الجوهري ، ابو نصر اسماعيل بن حماد الفارابي (rqسه/ץ + . ام

- الصحاح تاج اللغة والصحاح العربية ، تح: احمد عبد الغفور عطا

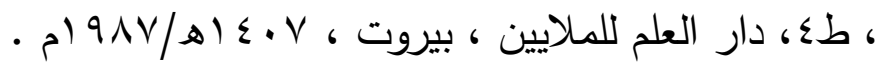
- حاجي خليفة ، مصطفى بن عبد الله (VT • اهـ/ 707 (م) . - - ســلم الوصــول الـى طبقـات الفـــول ، تـح: محمـود عبـــ القــادر

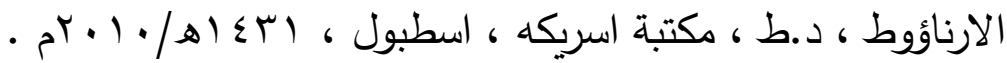

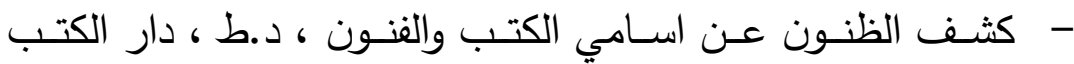

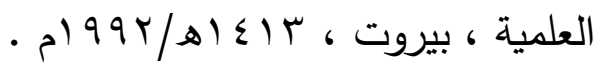

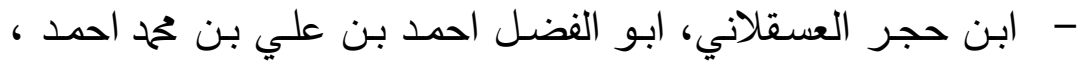

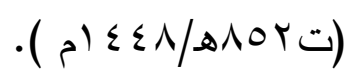

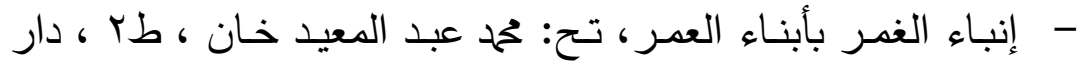

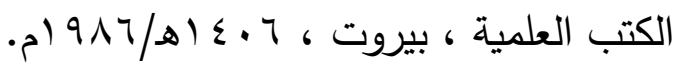

- الدرر الكامنة في اعيان المائة الثامنة، تح: عحم عبد المعيد ، طب ،

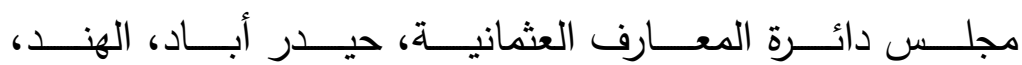

$$
\text { - ) } 9 V r / \Delta 14 q r
$$

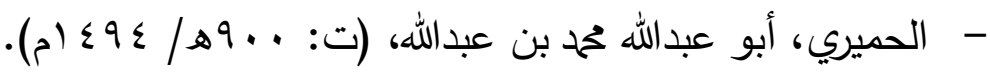
- الـروض المعطسار في خبر الاقطسار، تـح: احسـان عبـاس، طب،

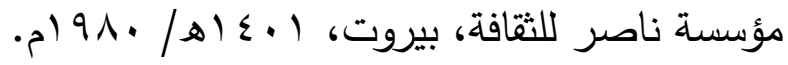




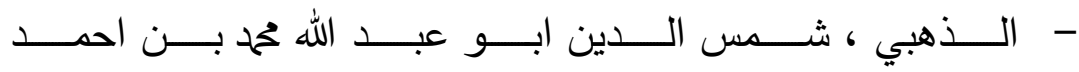

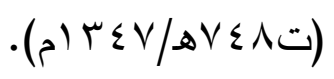

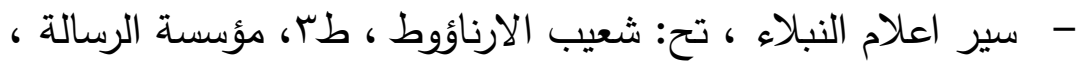

$$
\text { د.م ، } 1910 / 010.0
$$

- العبر في خبر من غبر ، تح: صـلاح الدين المنجد ، د.ط، مطبعة

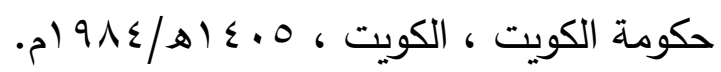

- الزبيدي، مرتضسى أبو الفيض ححمد بن ححمد بن عبد الرزاق الحسيني

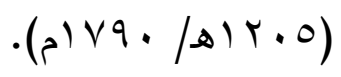

- - تاج العروس من جواهر القاموس ، تح : مجموعـة من المحققين،

$$
\text { (د. ط) ، دار الهداية(د.ت). }
$$

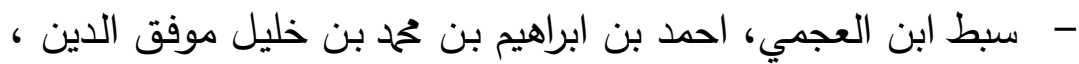

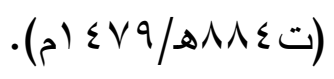

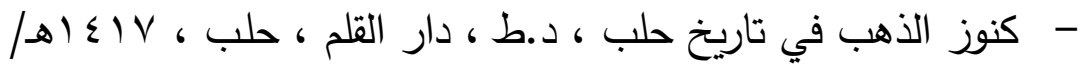
- ) 997

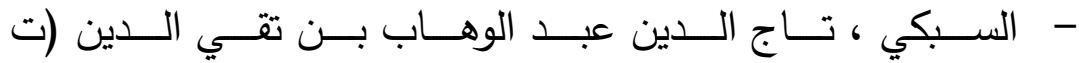

$$
\text { . (م) } 19 / 8 V V)
$$

- - طبقات الشافعية الكبرى ، تح : محمود محمد الطناحي و عبد الفتاح

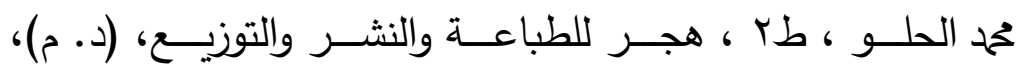
. 199r/ه إه

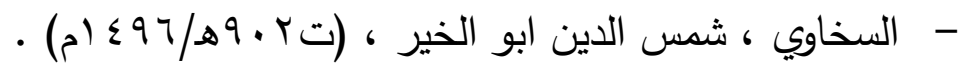
- الذيل على رفع الاصـر أو بغية العلمـاء والرواة، تح: جودة هـلال ومحمد صـبـح،(د.ط) الــدار المصـرية، للتـاليف والترجمـة، القـاهره، 
- الضوء اللامع لأهل القرن التاسع، د.ط ، مكتبة الحياة ، بيروت ، د.ت.

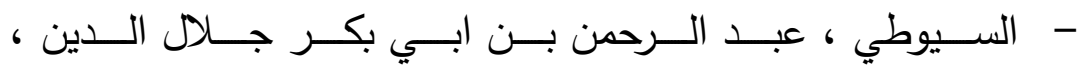

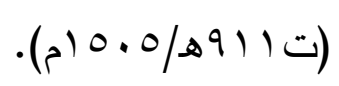

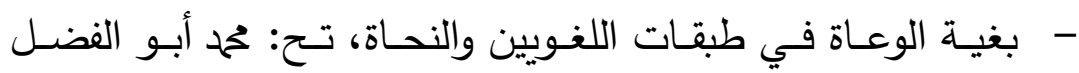

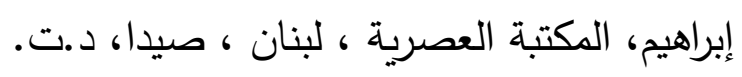

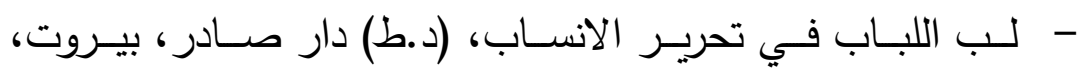

$$
\text { (د.د) }
$$

- - حسن المحاضـرة في تاريخ مصـر والقـاهرة ، تح: عحم ابو الفضـل

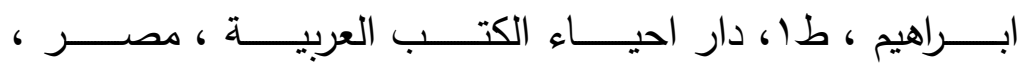

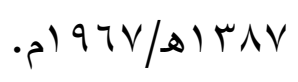

- - نظم العقيان في أعيان الأعيان، تح : فليب حتي ، د.ط ، المكتبة

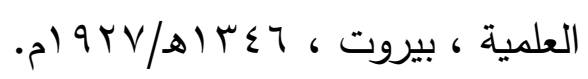

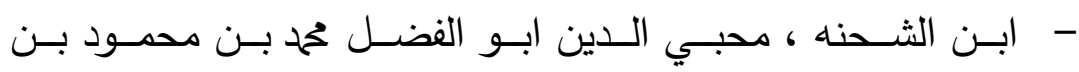

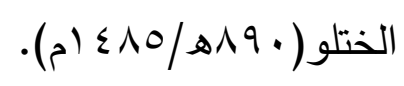

- الدر المنتخب في تاريخ مملكة حلب، تح: يوسف اليان سركيس،

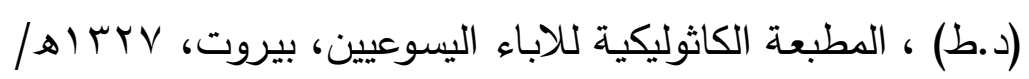

$$
\text { . } 9.9
$$

- - تـاريخ حلب ، اختيـار ابـن الثـنة المجهول ، تعليـق ابـو اليمن

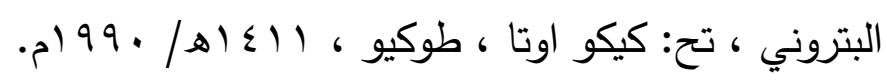

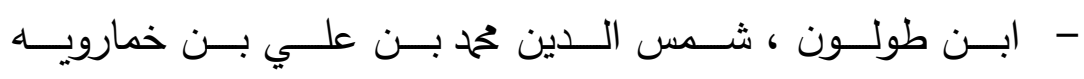

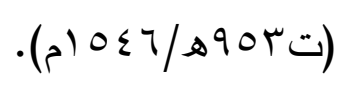


- مفاكهة الخلان في حوادث الزمان ، تح: خليل منصور ، طا، دار

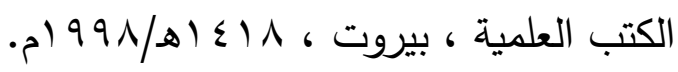

- بغية الطلب في تاريخ حلب، تح: سهيل زكار ،(د.ط) دار الفكر ،

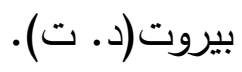

- العزيزي ، الحسن بن أحمد المهلبي العزيزي (ت . مشهـ/ • 99 م).

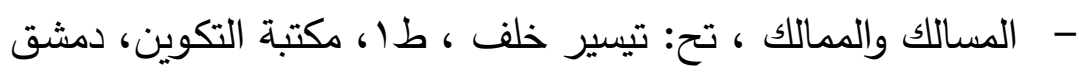

$$
\text { . }
$$

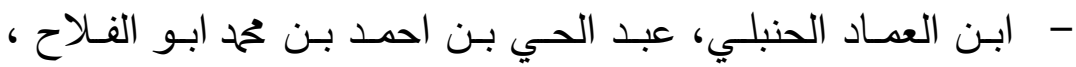

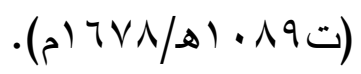

- شذرات الذهب في اخبار من ذهب ، تح: محمود الارناؤوط ، دار

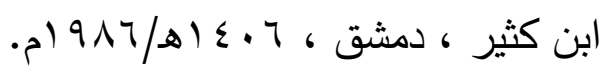

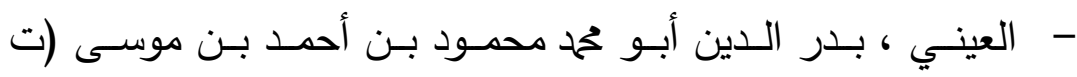
$\cdot(م) \leq 01 / 800$

- مغـاني الأخيار في شرح أسـامي رجال معـاني الآثار ، تح : محهد

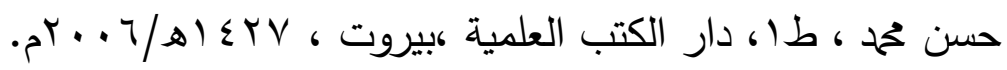

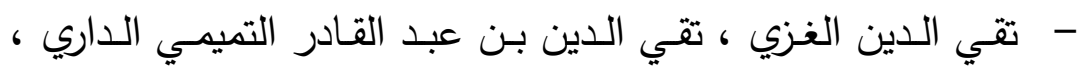

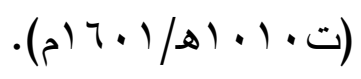

- الطبقات السنية في تراجم الحنفية ، د.ط ، د. دم ، د. د.ت. -

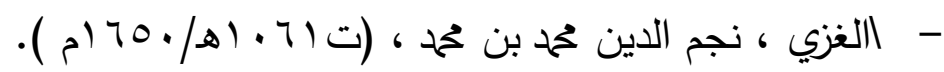

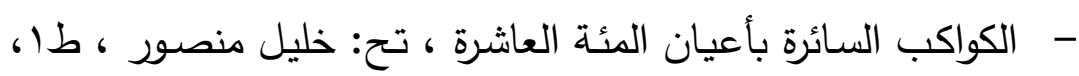

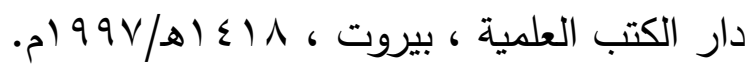

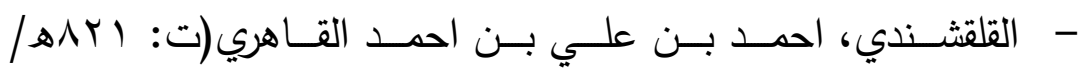
$\cdot($ ) $\leqslant 1 \wedge$ 


\section{ذكر ما بباطن حلب وظاهرها من المدارس "المدارس الشافية"}

- صبحى الاعشى في صناعة الانشاء، دار الكتب العلمية، بيروت،

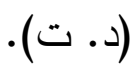

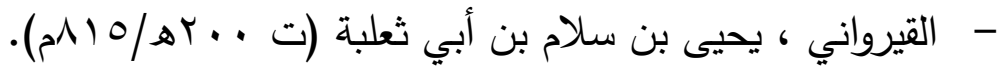

- تفسير القرآن، تح : هند شلبي، طا، دار الكتب العلمية ، بيروت ،

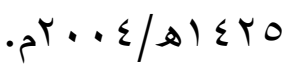

- المقريزي، أحمد بـن علي بـن عبد القـادر، أبو العباس الحسيني

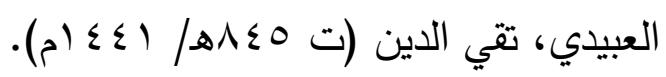

- المواعظ والإعتبار بذكر الخطط والآثار ، طا، دار الكتب العلمية

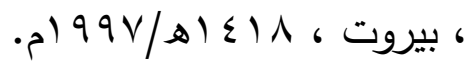

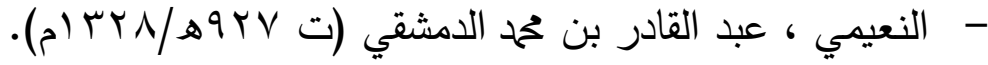
- الدارس في تاريخ المدارس ، تح : إبراهيم شمس الدين ، طا، دار

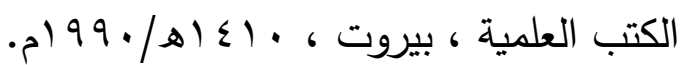

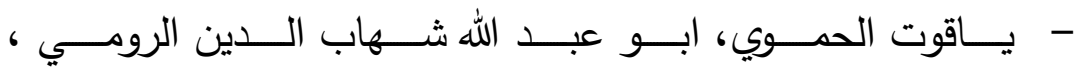

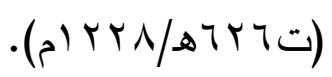

- معجم البلدان، ط ط، دار صادر ، بيروت ، 71 ، (اهـ/990 (م.

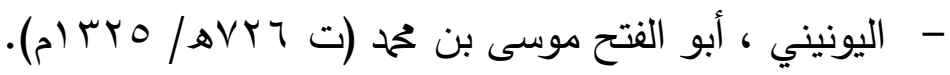

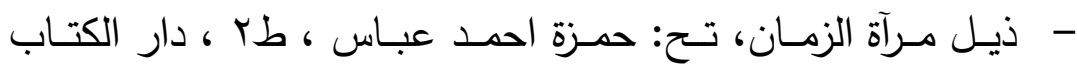

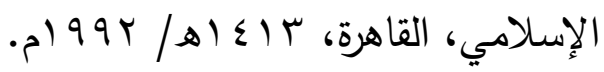

قائمة المراجع

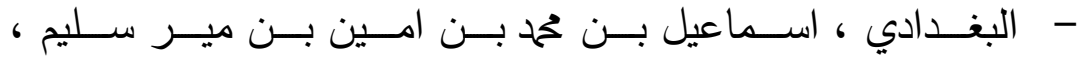

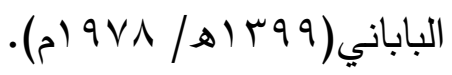

- ايضـاح المكنـون في الـذيل على كثف الظنـون ،تـح: عمد شـرف الدين، د.ط ، دار احياء التراث العربي ، بيروت ، د.ت. 
- بكر بن عبد الله ابو زيد بن محمد بن عبد الله بن بكر

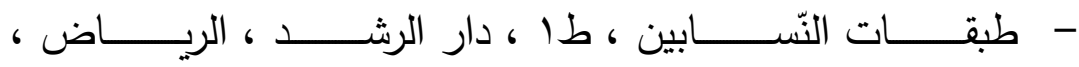

$$
\cdot \text { •) } 9 \wedge v / ه 1 \leq \cdot v
$$

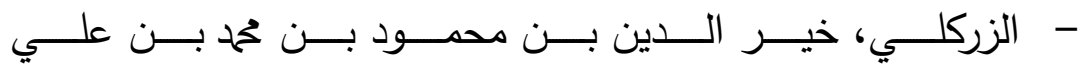

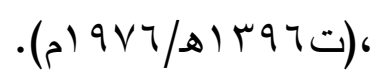

- الأعــلام ( قـاموس تـراجم لاشـهر الرجـال والنسـاء مـن العـرب

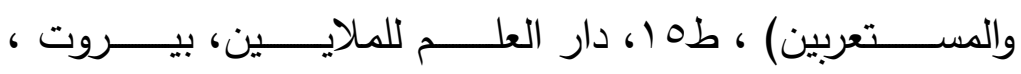

$$
\text { . } 99 \cdot 9 \cdot / 81 \leq 11
$$

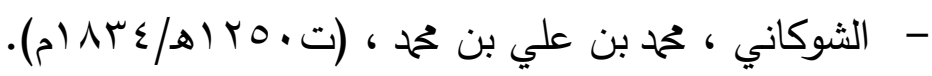

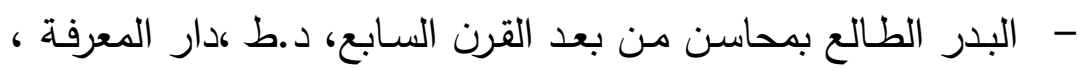

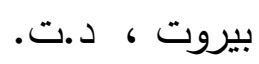

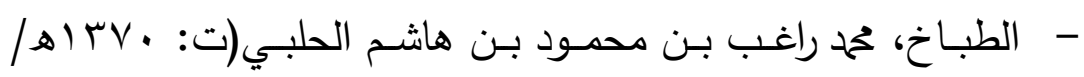

$$
\text { (a) } 90 \text {. }
$$

- اعلام النبلاء بتاريخ حلب الشهباء، تح: محمد كمال ، طب، دار القلم

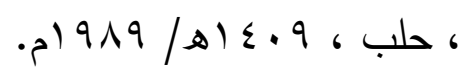

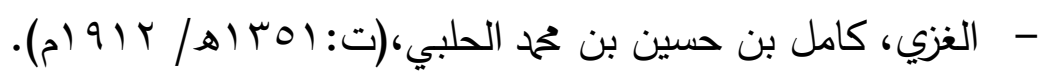

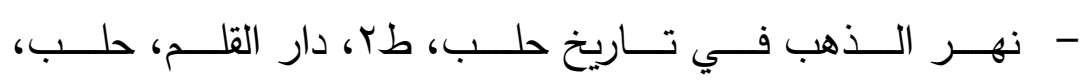

$$
\text { . } 991 / 81 \leq 19
$$

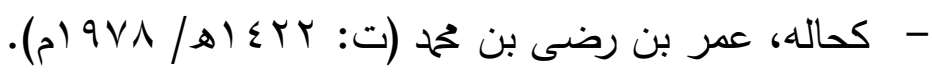

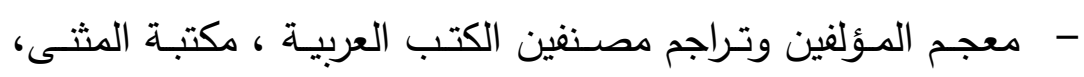

$$
\text { بغداد، (د.ت). }
$$

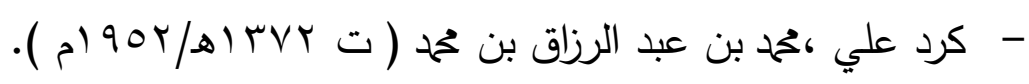

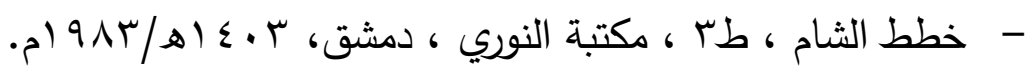


ذكر ما بباطن حلب وظاهرها من المدارس "المدارس الشافية”"

$$
\text { - - الثمري، جنان علي فليح }
$$

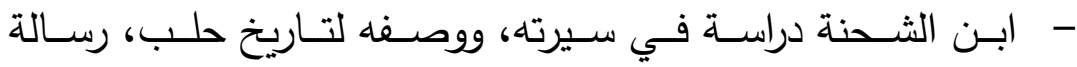

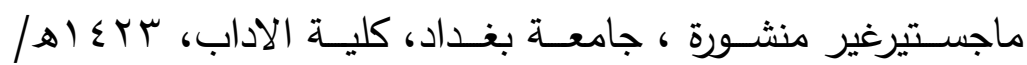

$$
\cdot r+r
$$




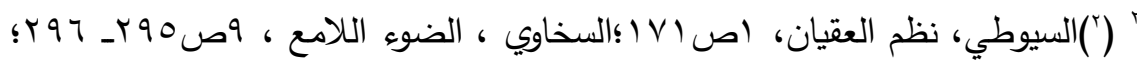

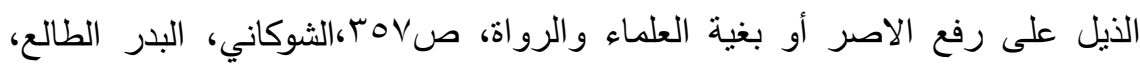

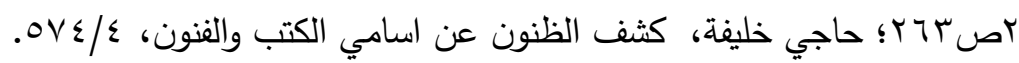

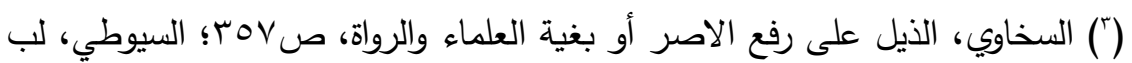

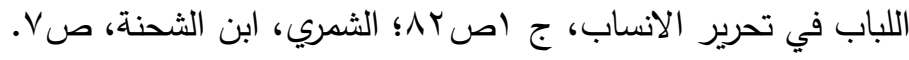

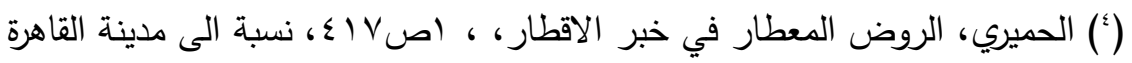

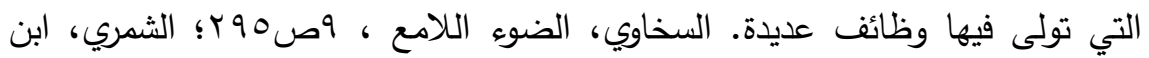

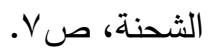

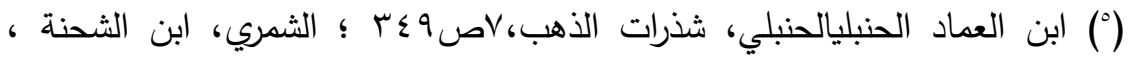

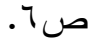

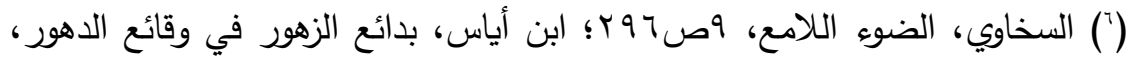

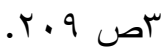

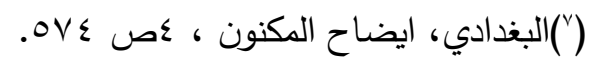

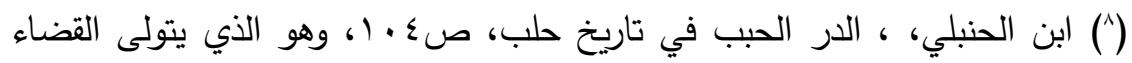

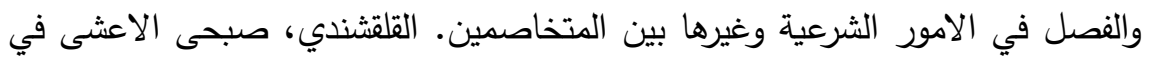

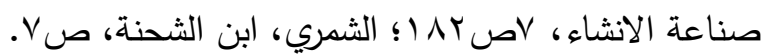
(") السخاوي ، الضوء اللامع ، آصو1 ؛ الزركلي ، الاعلام ، لاصاه اه ؛ بكر ،

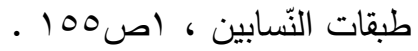

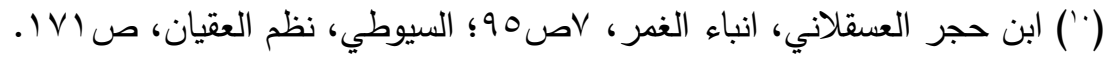

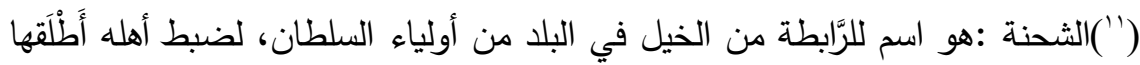

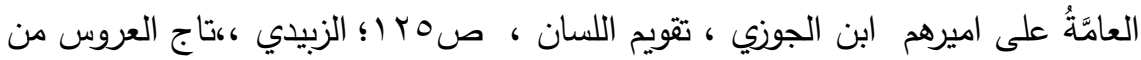

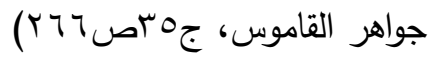
(') الملك الصالح اسماعيل : اسماعيل بن نور الدين محمود زنكي ابن اق سنقر

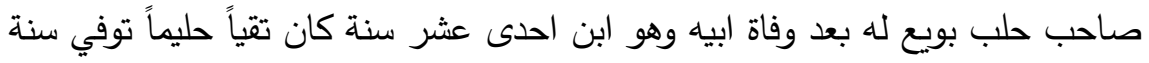




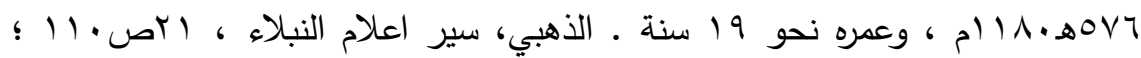

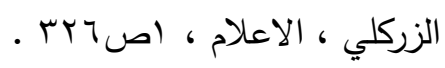

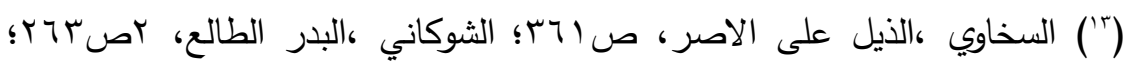

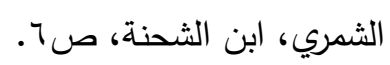

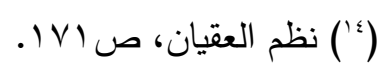

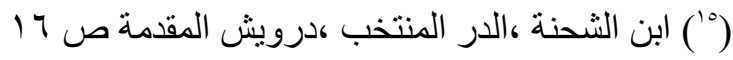

(') المدرسة الحسامية : تقع في حلب وراء جامع الناصرية انشأها الامير حسام الدين

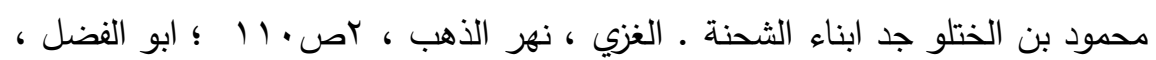
حمح بن الثحنة، تاريخ حلب ، وهو فصل من كتابه نزهة النواظر ، اختيار ابن الثحنة

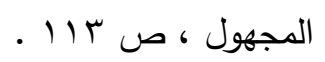

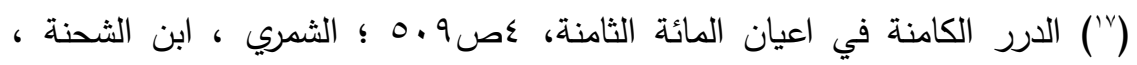

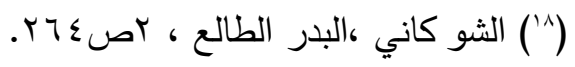

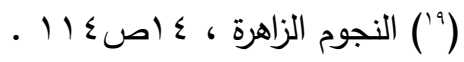

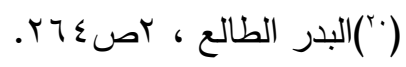

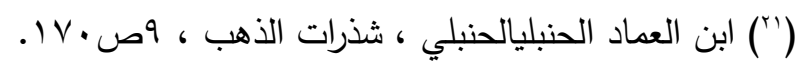

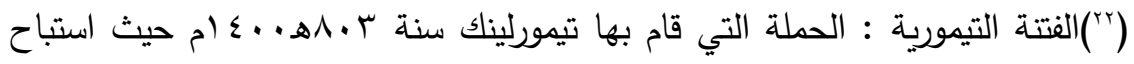
حلب وبعض مدن الثام الاخرى وقام بقتل الكثير من الناس ومنهم الامراء والعلماء ونهب المدينة وشرّد اهلها وجعلها مدن خاوية كانها هيكل عظمي لا يوجد فيه حياة ويقول المؤرخين دمرها في ثلاثة اشهر ويحتاج اعمارها الى قرن من الزمان ـ كرد علي،

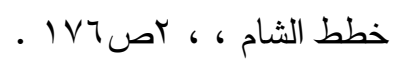

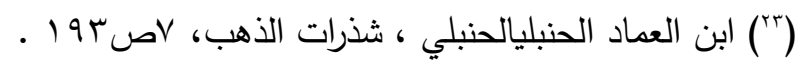

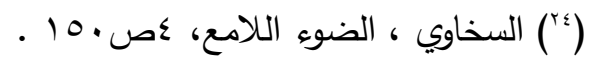

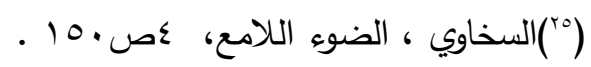

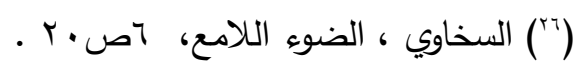

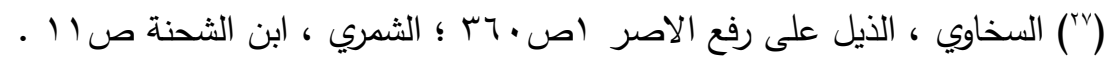




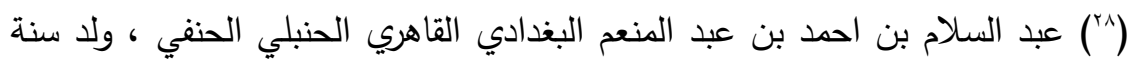
كه PVY

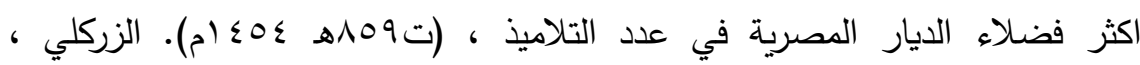

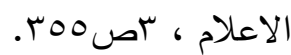

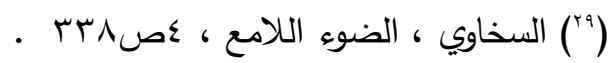

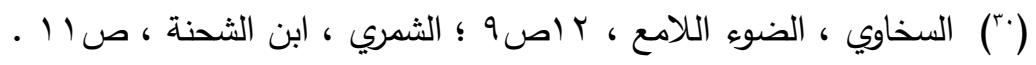

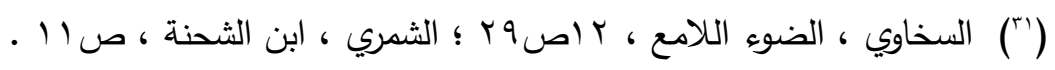

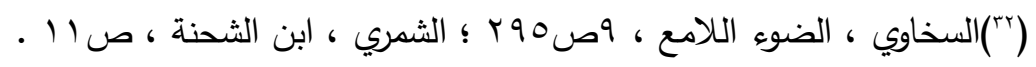

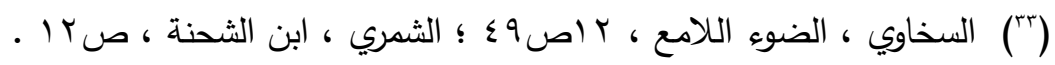

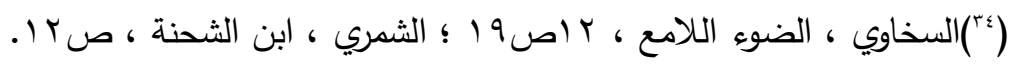

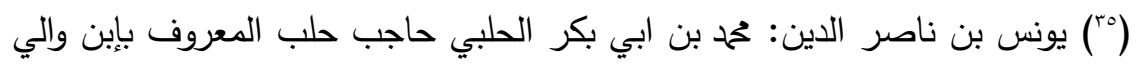

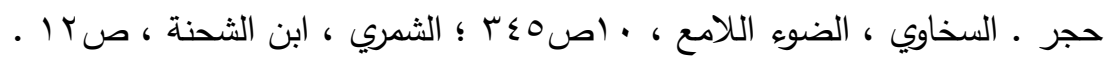

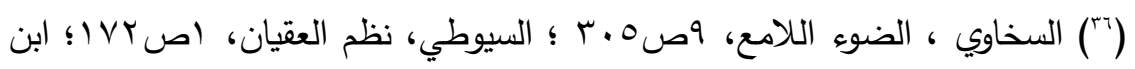

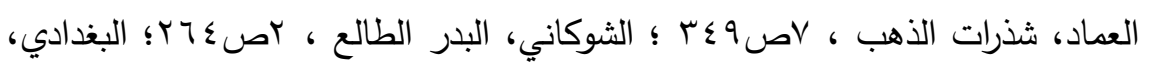

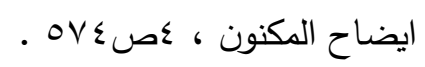

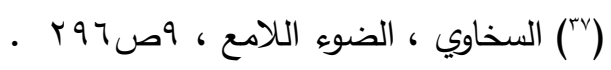

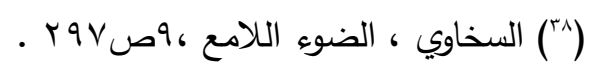

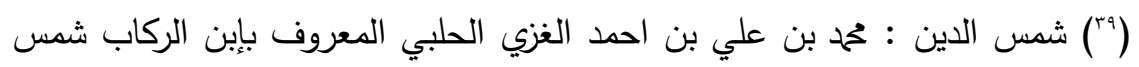

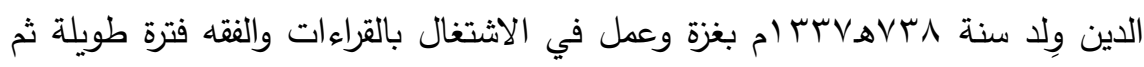

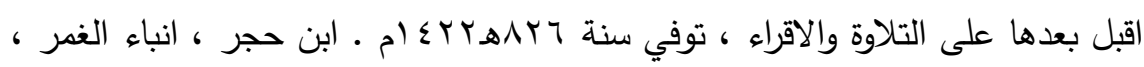

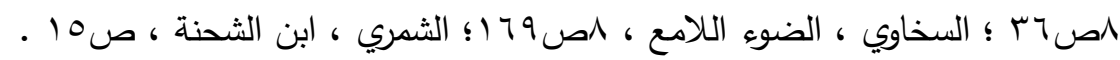

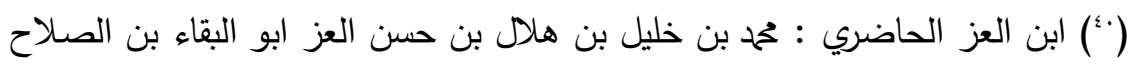

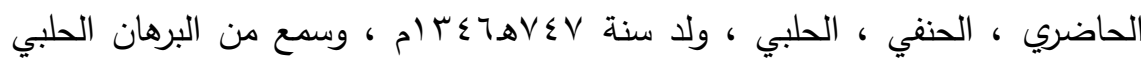

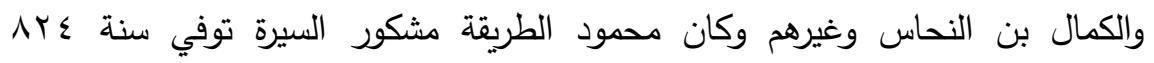

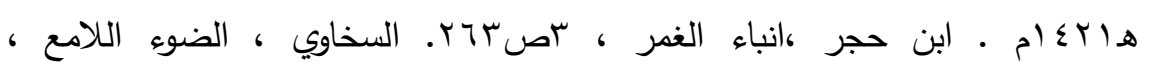
קטזrr. 
('أ) المارديني : محمد بن ابي بكر بن محمد بن سلامة الحلبي الحنفي المارديني الاصل

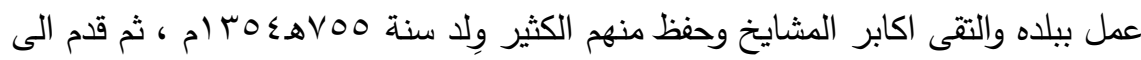

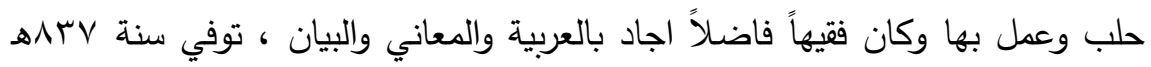

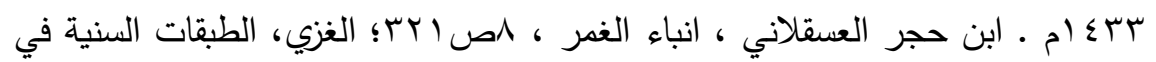

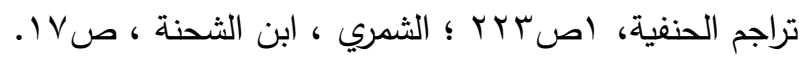

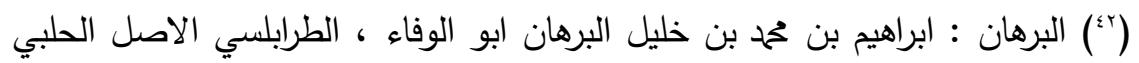

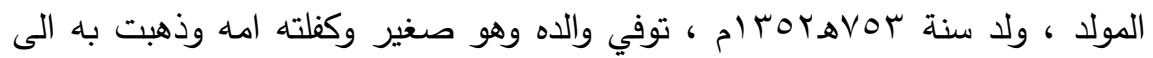

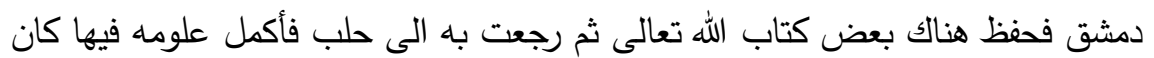

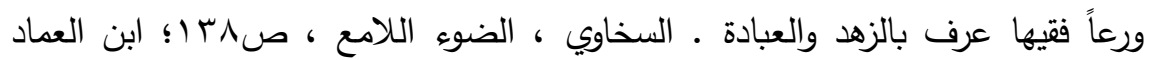

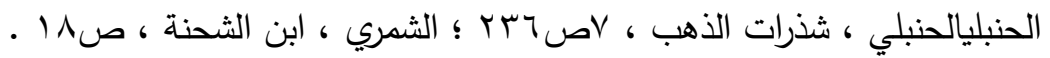

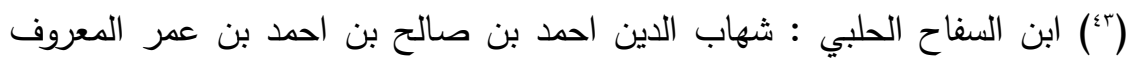

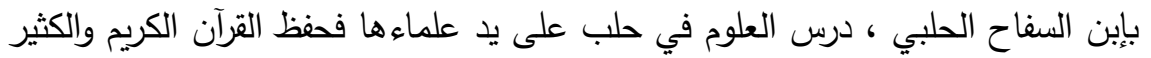

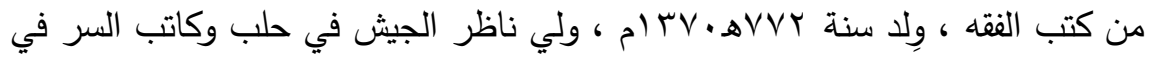

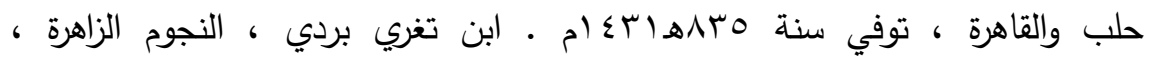

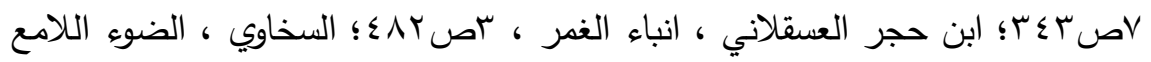

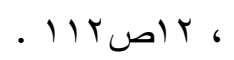

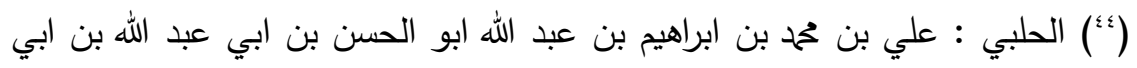

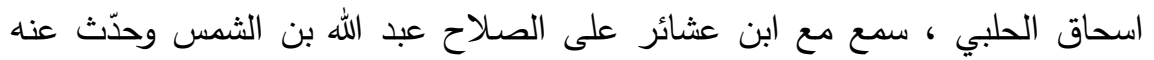

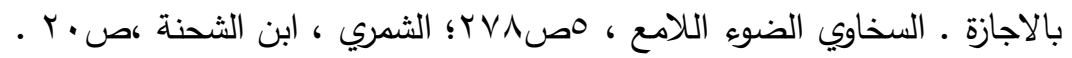

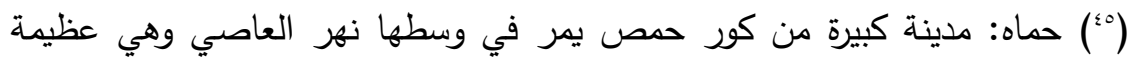

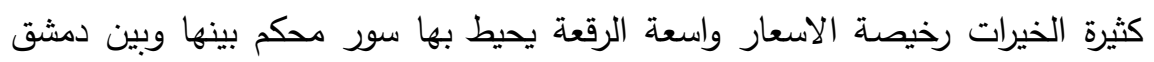

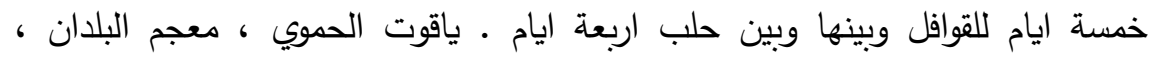
זص...

("^) ابن خطيب الدهثة : محمود بن احمد بن محم نور الدين الحموي ابن خطيب

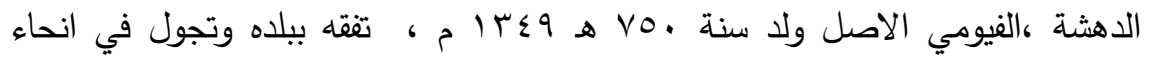
الثام ومصر طلباً للعلم ثم ولي قضاء حماه في دولة المماليك ثم صرف عنده عنها فلزم بيته 


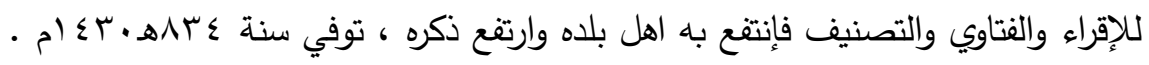

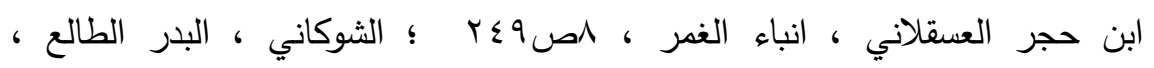

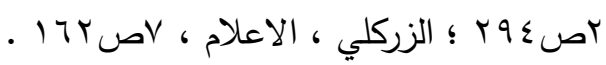

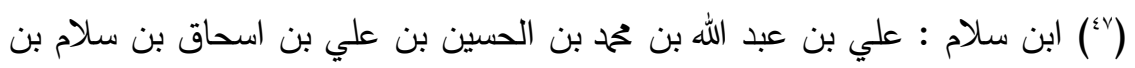

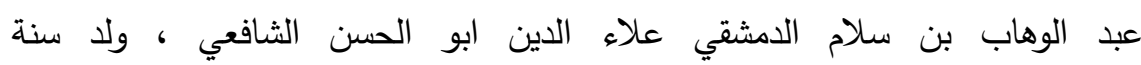

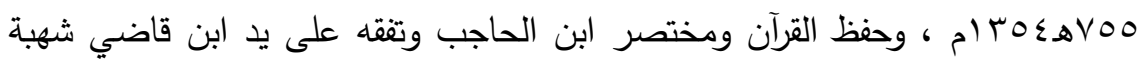

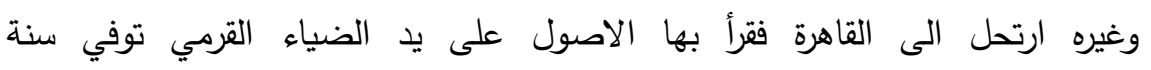

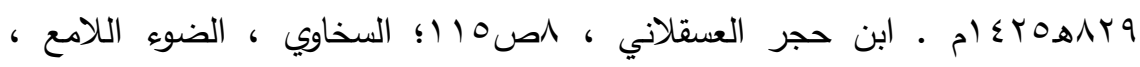
Oص

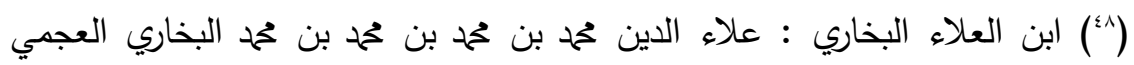

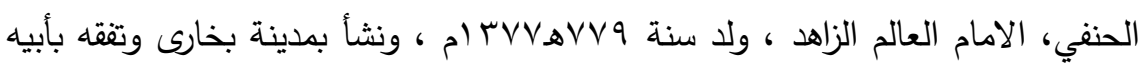

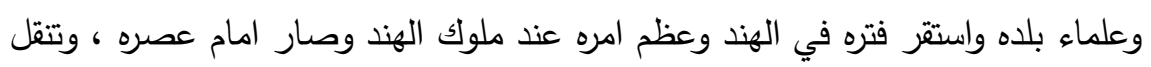

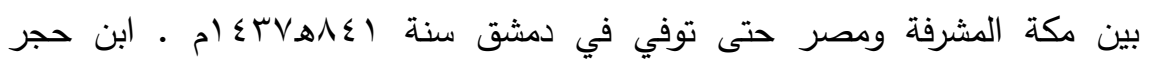

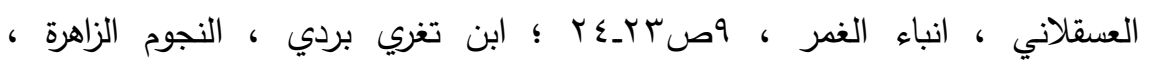

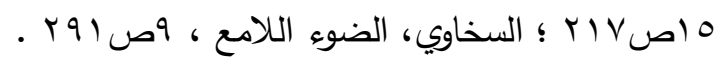

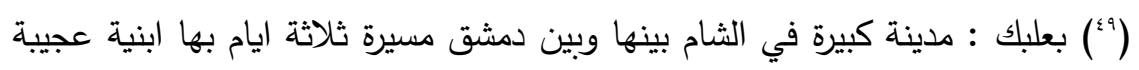

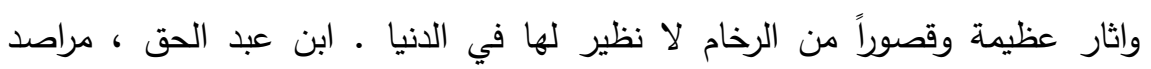

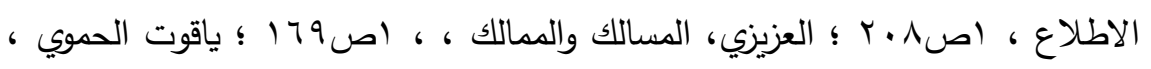

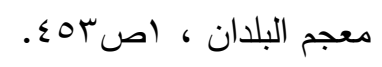

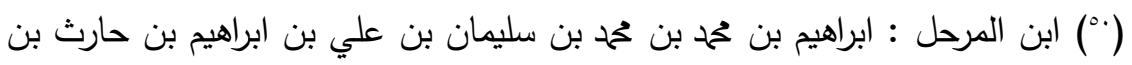

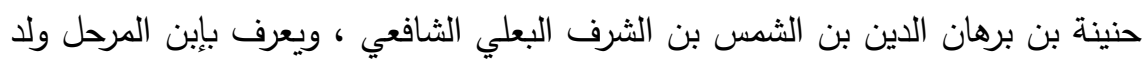

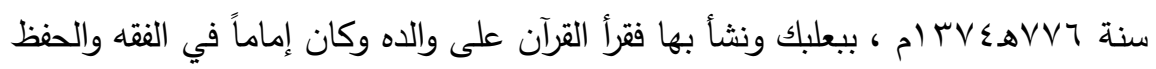

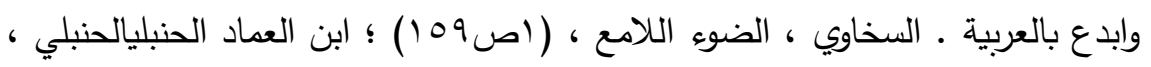

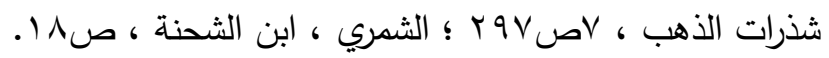

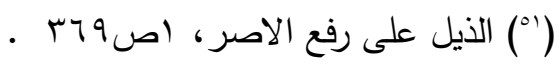


(الثمس بن عمران : محمد بن موسى بن عمران بن موسى بن سليمان الثمس الغزي

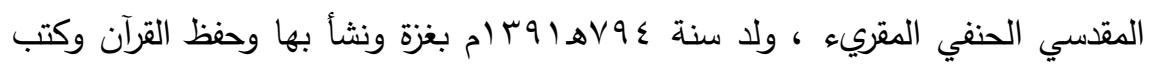

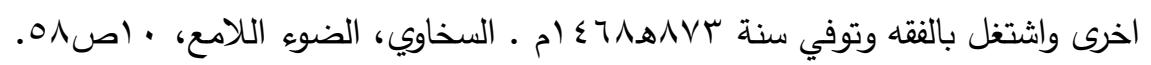

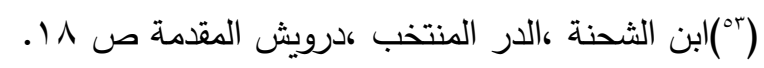

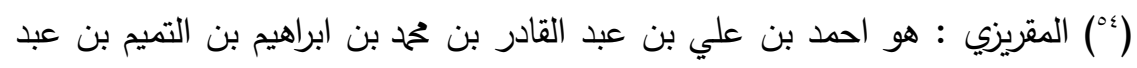

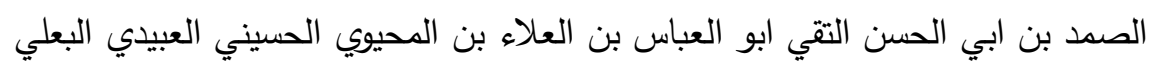

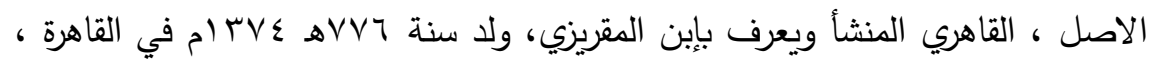

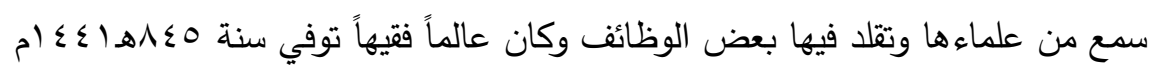

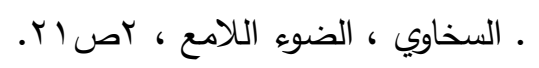

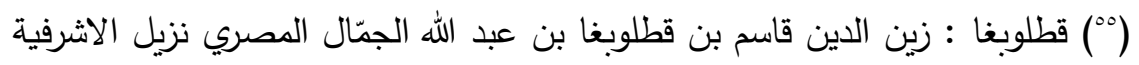

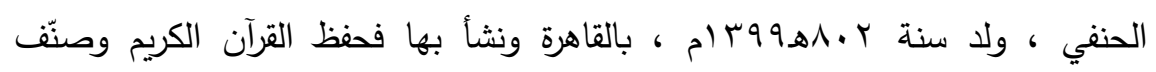

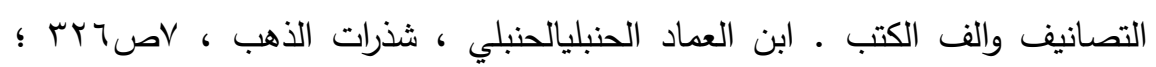

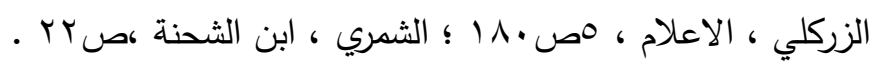

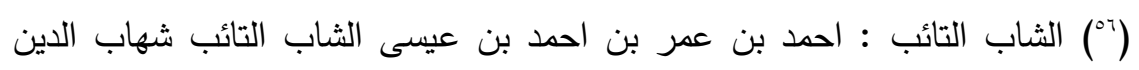

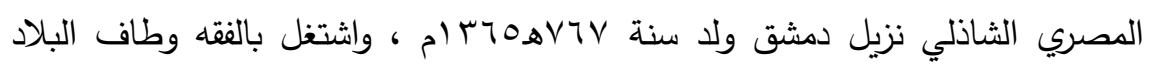

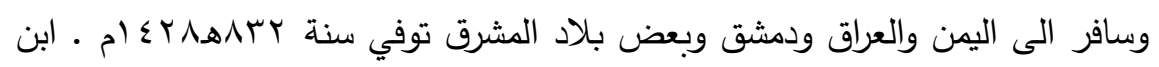

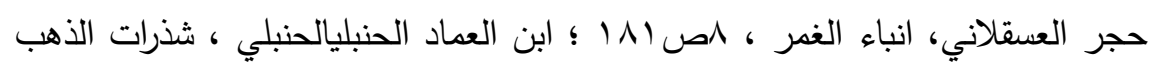

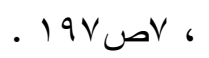

(ابو ذر الحلبي : احمد بن ابراهيم بن محمد بن خليل الطرابلسي الاصل الحلبي

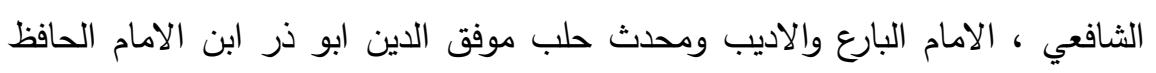

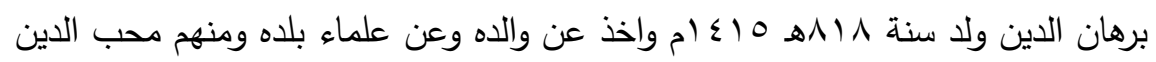

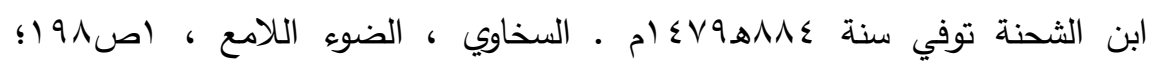

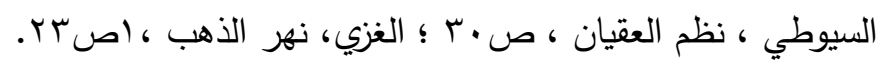

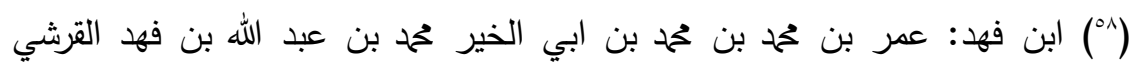

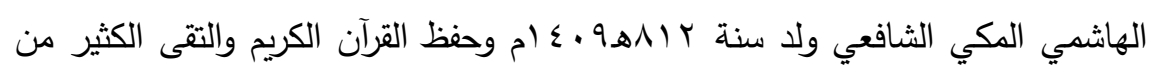




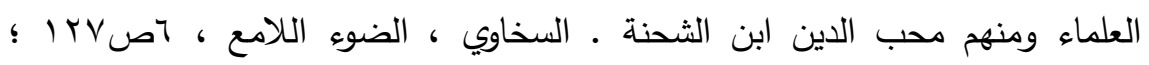

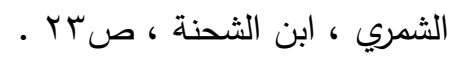

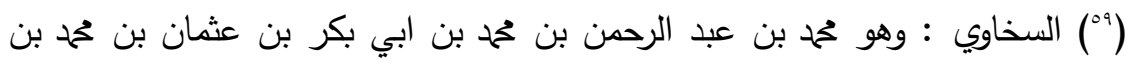

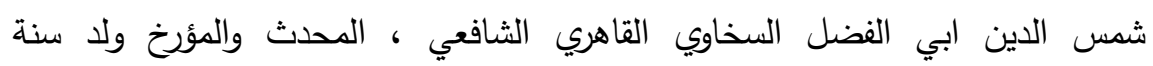

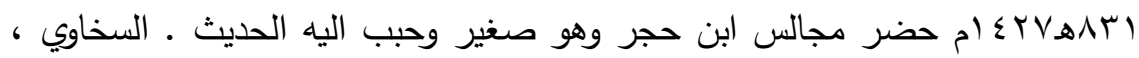

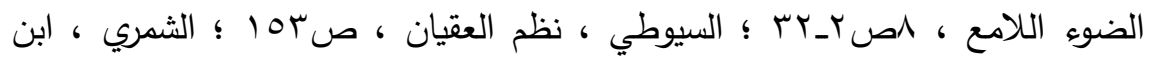

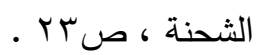

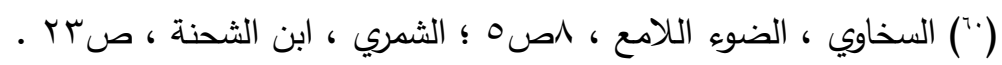

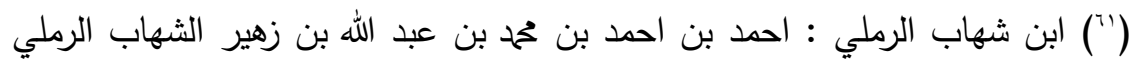

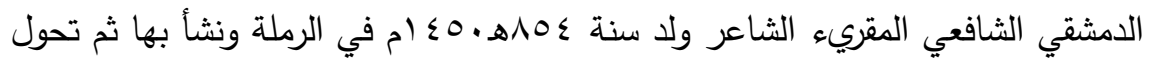

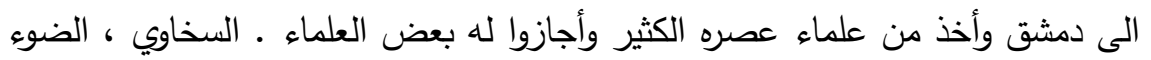

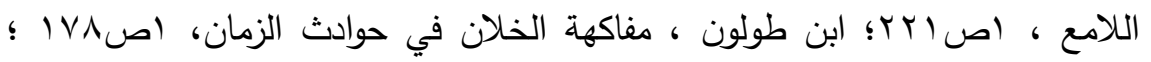

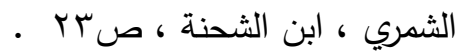

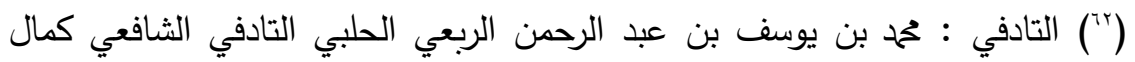

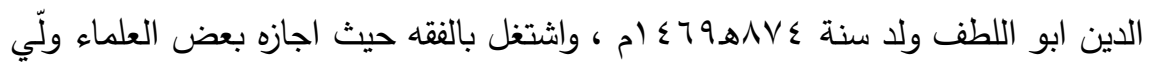

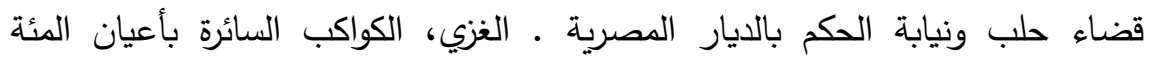

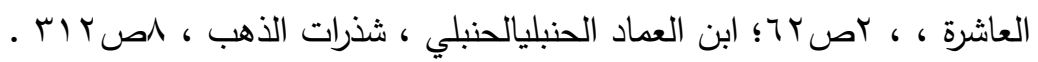

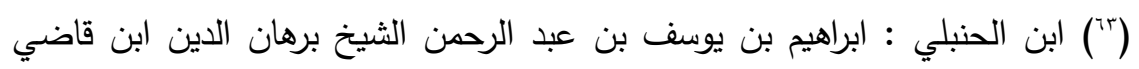

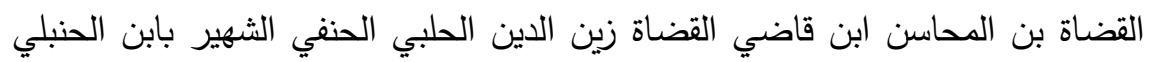

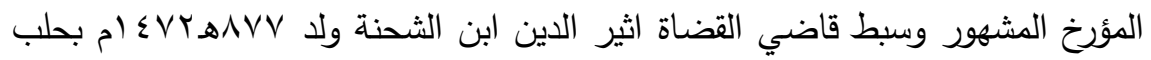
واشتغل في الصرف والنحو والعروض والمنطق اجازه الكثير من العلماء ومنهم محب التب التبن

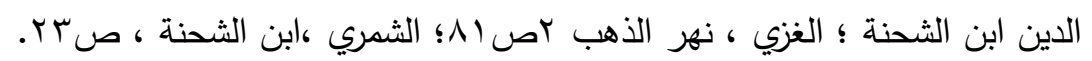

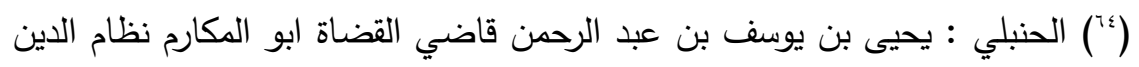

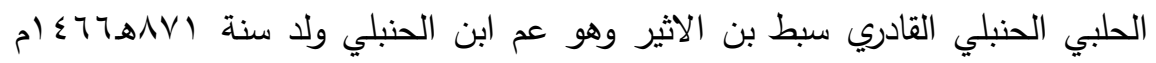
وتقفه على يد ابيه واجاز له العلماء باستدعاء من والده ومنهم الدحب ابن الثئ ولن الثحنة 
فأصبح من علماء عصره وناب عن والده في قضاء الحنابلة بحلب ـ الغزي ، الكواكب

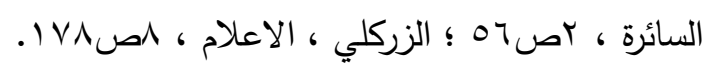

(10) العباسي : بدر الدين ابو الفتح عبد الرحيم بن احمد السيد شريف العباسي الثافعي

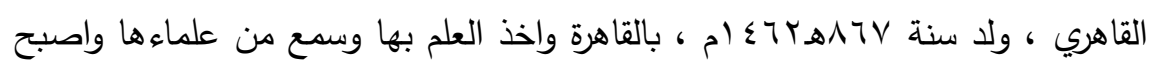
من مشاهير عصره ـ الغزي، الكواكب الساهرة ، اص. بr ؛ ابن العماد الحنبليالحنبلي

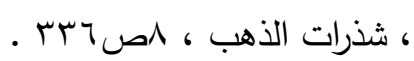

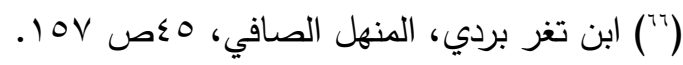

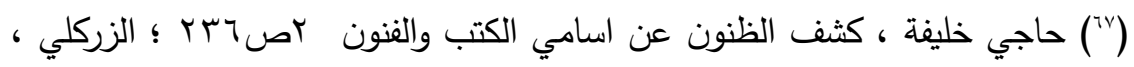

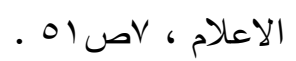

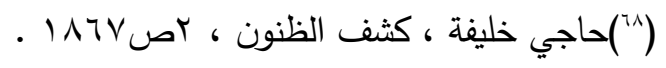

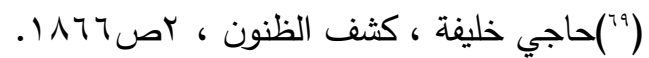

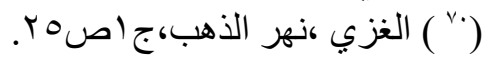

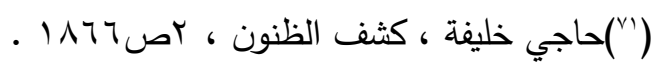

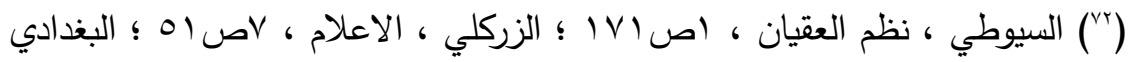

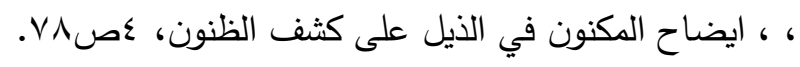

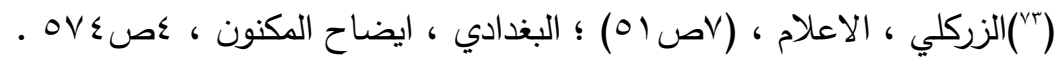

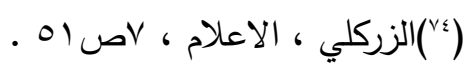

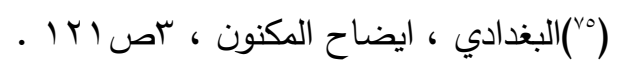

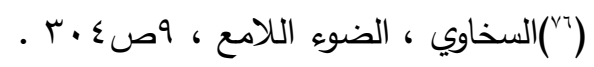

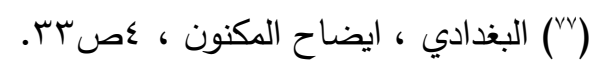

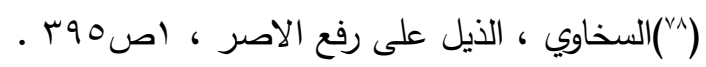

(199) كاتب السر : وهي وظيفة يتولى كاتب السر فيها قراءة الكتب الواردة الى السلطان والرد عليها وأخذ خط السلطان عليها وتعريف المراسيم وهي وظيفة مههة وذلك لقربها من السلطان وتحكمها بأمور السلطنة ـ القلقشندي ، صبحي الاعثى ، عص. •؟ . 
(“) ناظر الجيش : وهي التحدث في أمر الاقطاعات بالثام ومصر ومشاورة السلطان

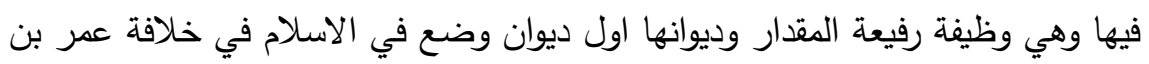

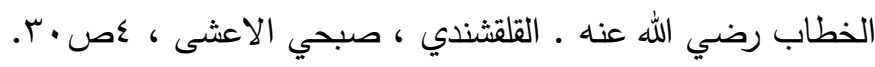

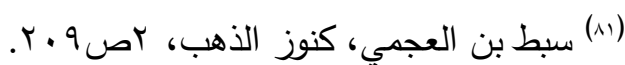

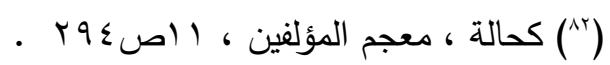

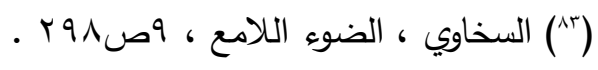

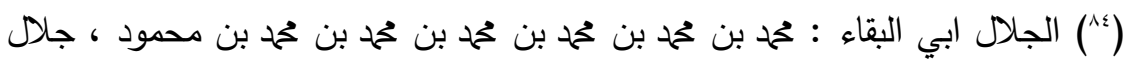

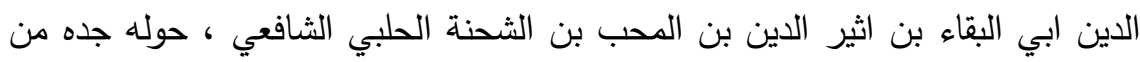
مذهب الحنفية الى مذهب الثافعية ليكون قاضي حلب ويستريح جده من مناكدة

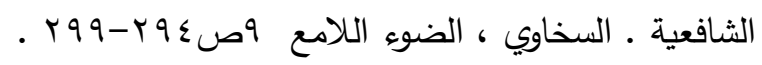

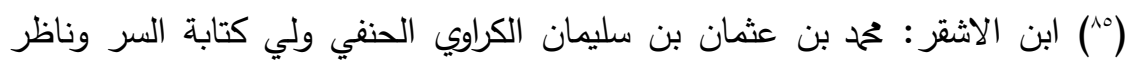

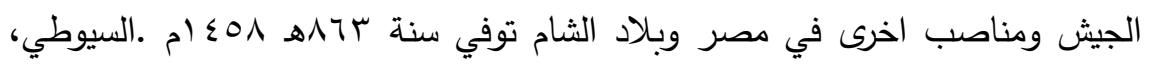

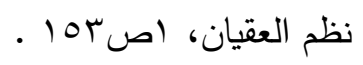

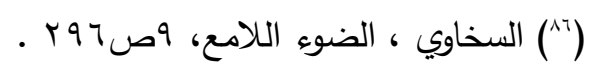

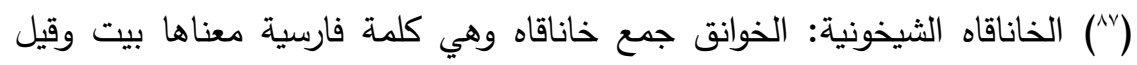
اصلها خونقاه اي الموضع الذي يأكل فيه الملك، وظهرت اول مره في حدود القرن الرابع

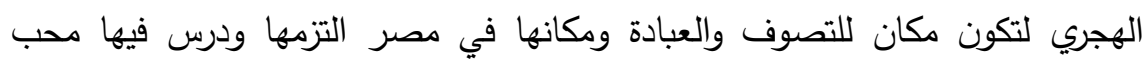

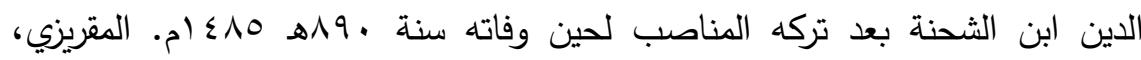

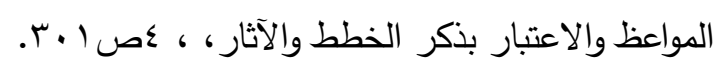

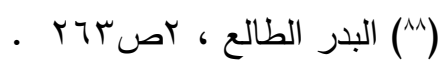

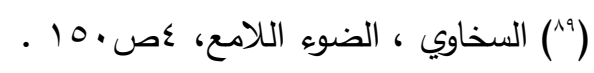

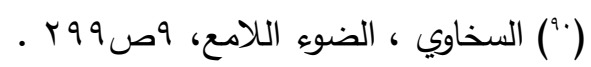

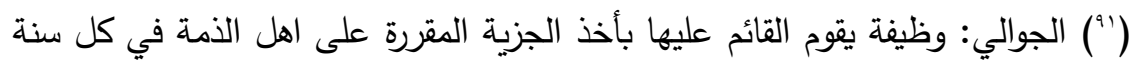

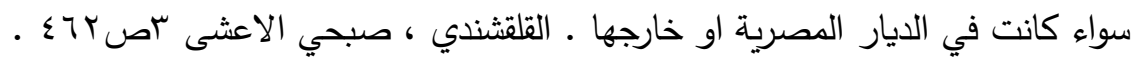

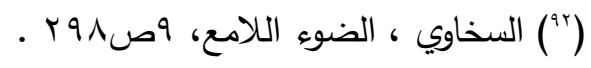

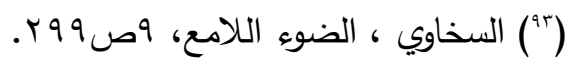




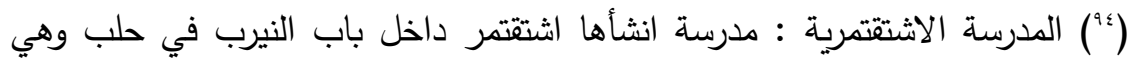

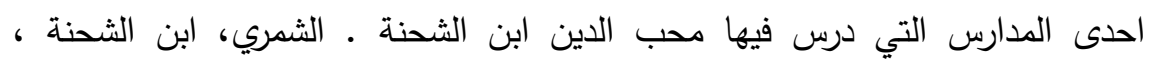

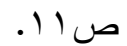

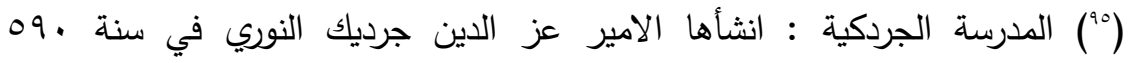
هـوالام ودرّس فيها الثيخ مقرب الدين ابو حفص بن قثام التميمي وعلاء الدين

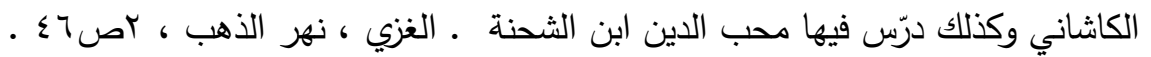

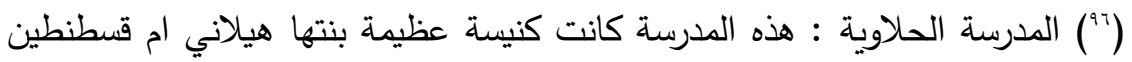
واخذها القاضي ابو الحسن الخشاب من النصارى بعد محاصرة الأفرنج لحلب وبعثرت

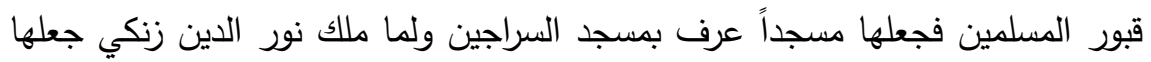

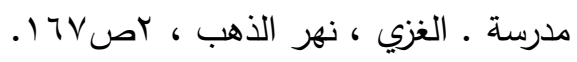

(7v) المدرسة الثاذبختية : مدرسة تقع بدرب العدول بقرب سوق النشابة انثأها الامير

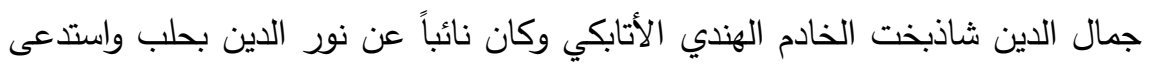

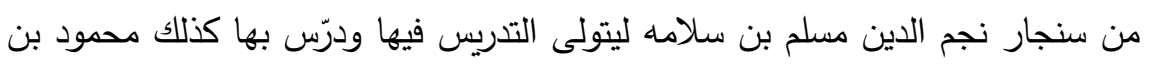
هبة الله بن النحاس اضافة الى ابن الثحنة محب الدين ـ سبط ابن العجمي، كنوز

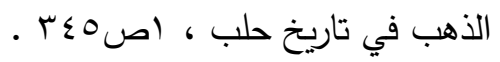

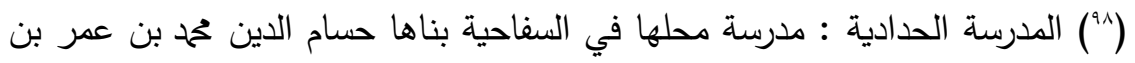

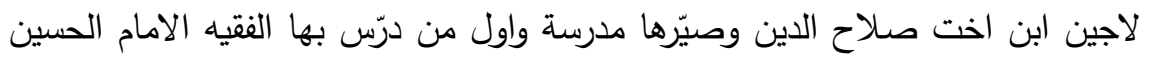

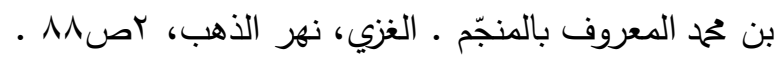

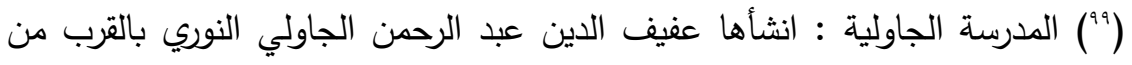

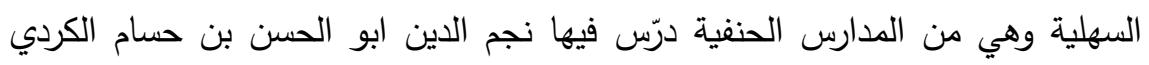

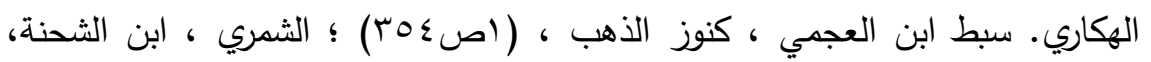

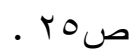

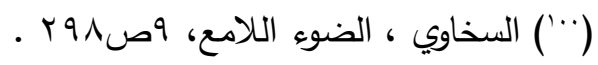

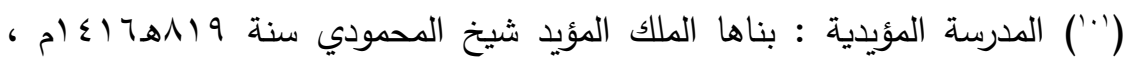
وبلغت النفقة عليها اربعون الف دينار وسميت بالمؤيدية نسبة له ــ السيوطي، حسن لهن

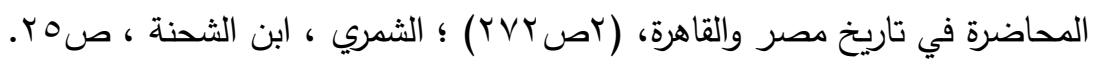




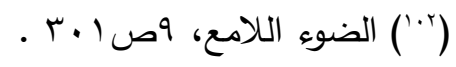

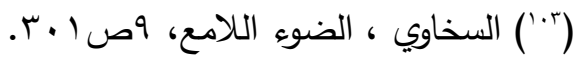

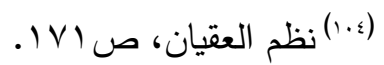

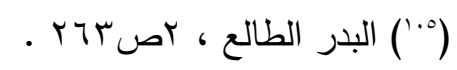

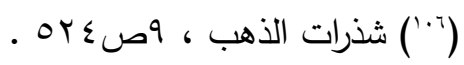
$.19 \leq 9 / r\left({ }^{1 . v}\right)$

$. r 0 / 1\left({ }^{1.10}\right)$

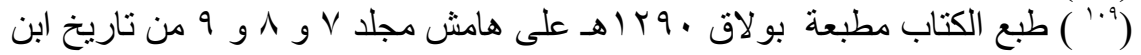

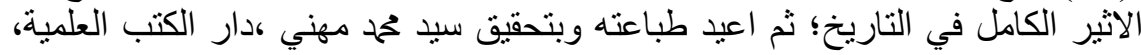

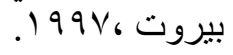

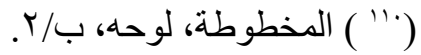

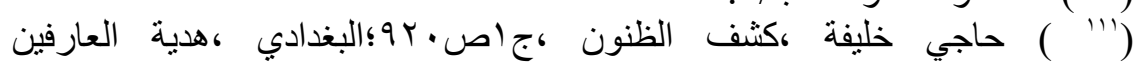

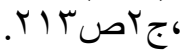

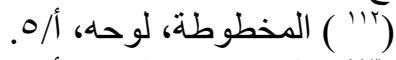

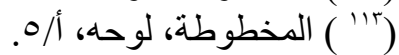

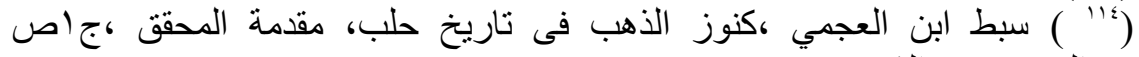

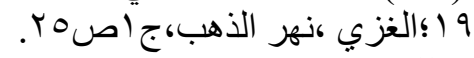

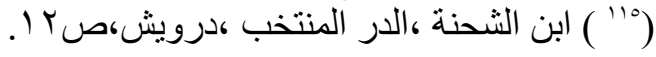

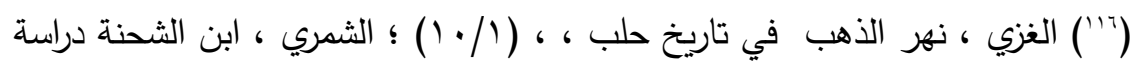

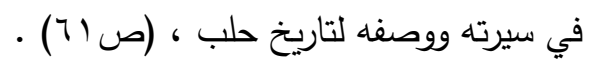

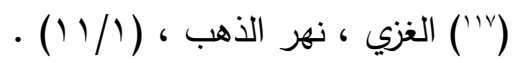

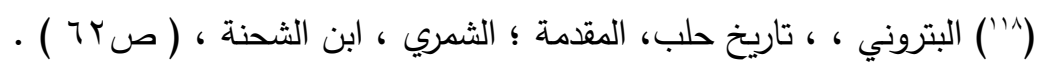

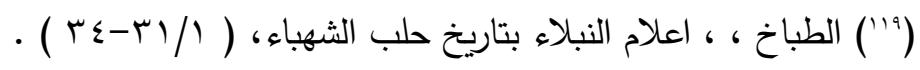

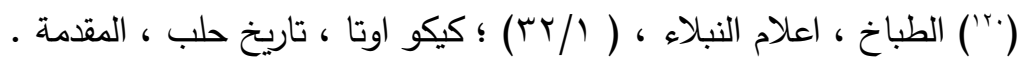

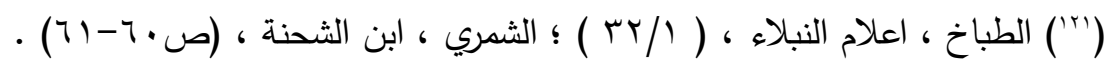

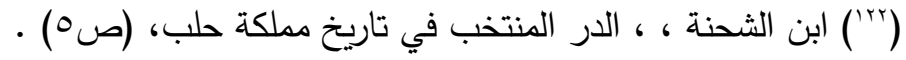

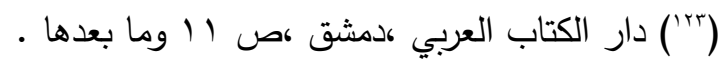

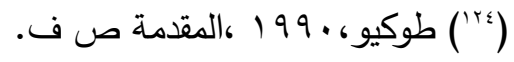

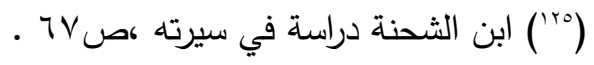

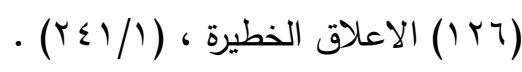




$$
\begin{aligned}
& \text { ( إبتدا منها) (IV) }
\end{aligned}
$$

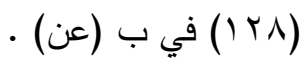

(1) (1) الدرسة الزجاجية الثافعية : سميت باسم السوق الذي هي فيه حيث كان هناك معمل للزجاج وهي أول مدرسة بنيت في حلب وكانت قديماً تدعى بالشرفية باسم بانيها

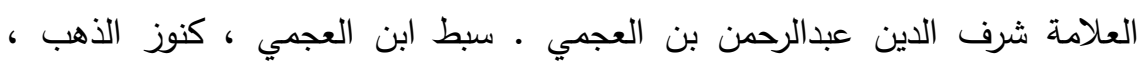
$\cdot(r V \cdot / l)$

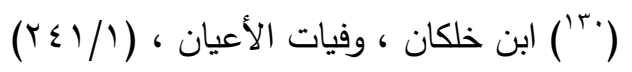

$$
\begin{aligned}
& \text { (اس ا (اب) في ب (ابتدا) . }
\end{aligned}
$$

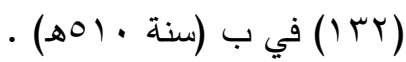

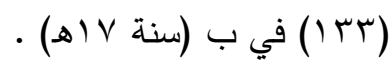

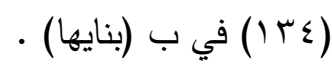

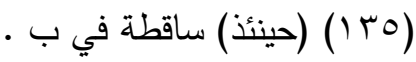

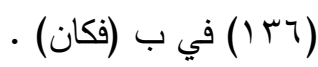

(IrV) الثريف زهرة بن علي بن حمح بن أبي ابراهيم الاسحاقي الحسيني : هو ابن زهرة

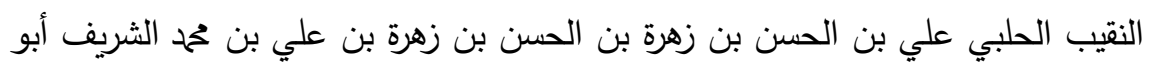

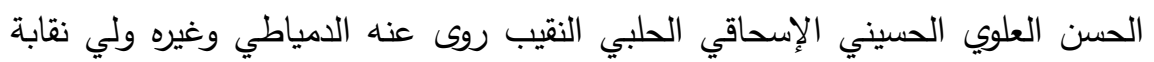
الأشراف وترسل عن صاحب حلب إلى بغداد ، وغيرها ، توفي سنة (707 7هـ/ 101 الهـ

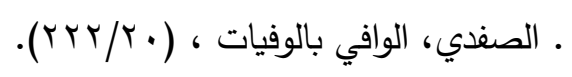

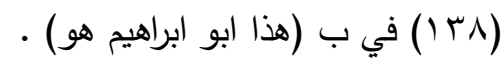

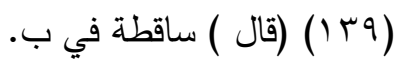

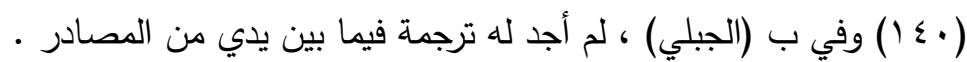

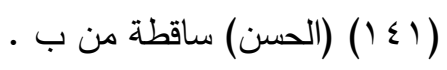

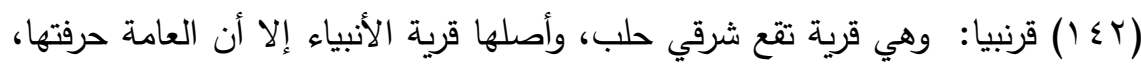

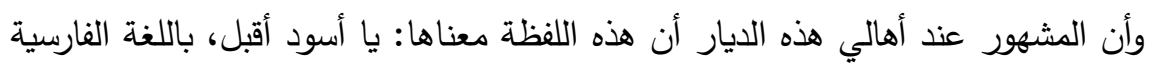

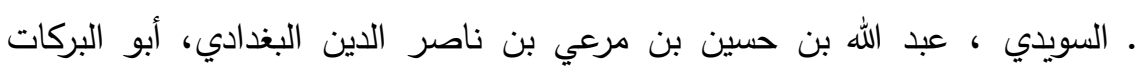


(ت \& ا I ا هـ) ، النفحة المسكية في الرحلة المكية ، د. ط ، المجمع الثقافي، أبو ظبي

$$
\begin{aligned}
& \text {. } \\
& \text { (اس ع () في ب (الحسن). }
\end{aligned}
$$

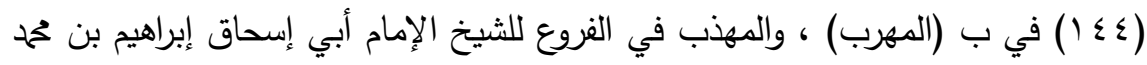

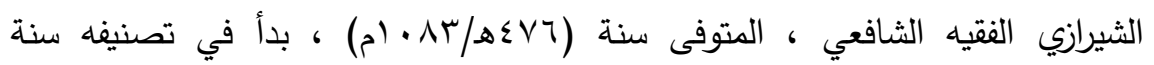

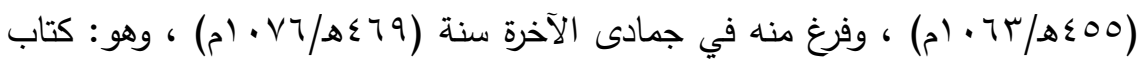

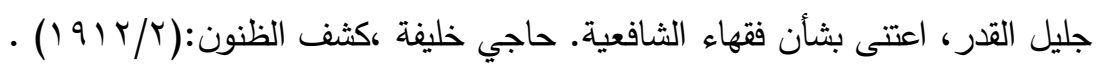

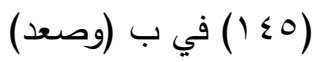

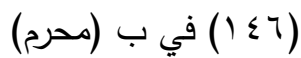

$$
\begin{aligned}
& \text { (بعده) ساقطة من ب ( }
\end{aligned}
$$

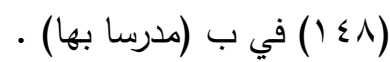

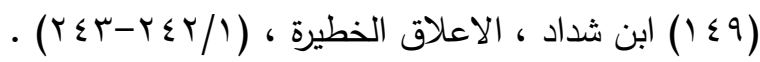

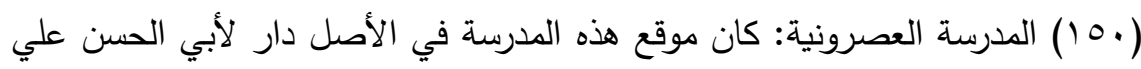

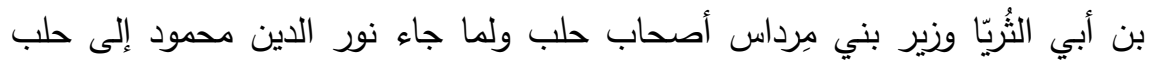

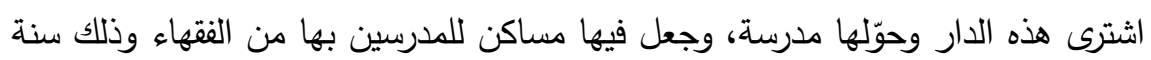

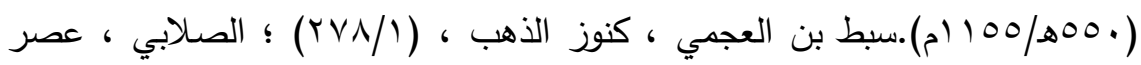

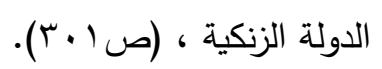

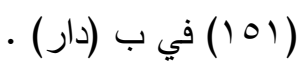

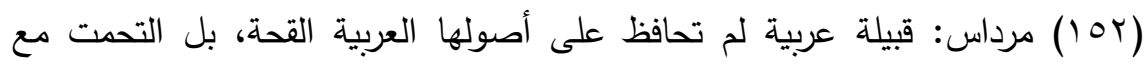
بعض القبائل البربرية بالمصاهرة والجوار، فحصل بينهما امتزاج كبير بابتلاع العرب مبله

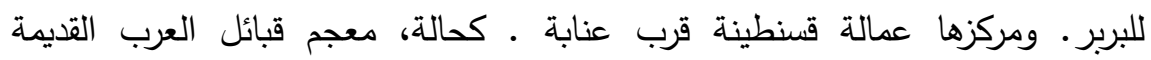

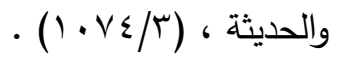

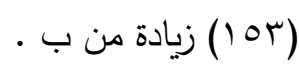

$$
\begin{aligned}
& \text { (10 1) في ب (ابي سعيد) (10) }
\end{aligned}
$$

(100) الموصلي الثافعي : هو قاضي القضاة الإمام أبو سعد الثيخ شرف الدين عبد

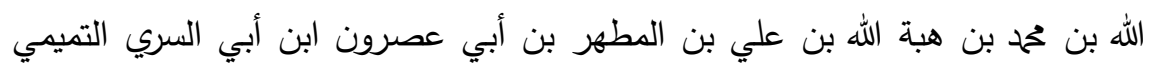


الموصلي، نزيل دمشق وقاضي القضاة بها وعالمها ورئيسها، مولده في شهر ربيع الأول

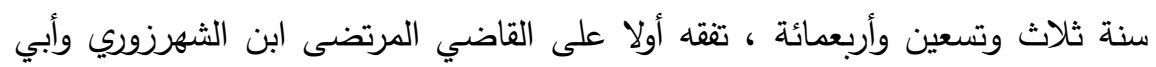

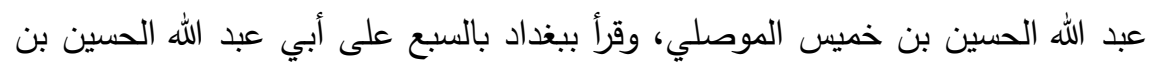

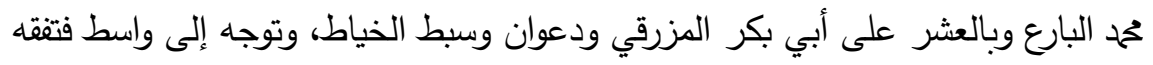

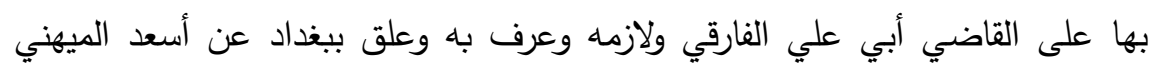

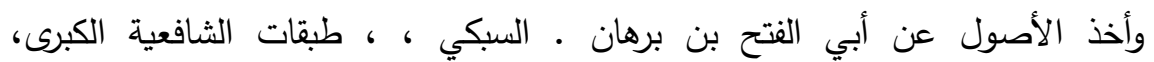

$$
\begin{aligned}
& \text {. (Irr/V) } \\
& \text { (107) في ب (الثهروزي) (10Y) }
\end{aligned}
$$

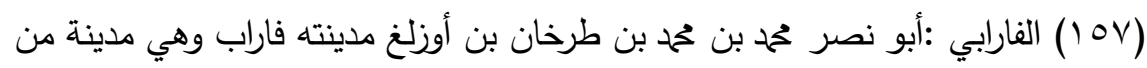

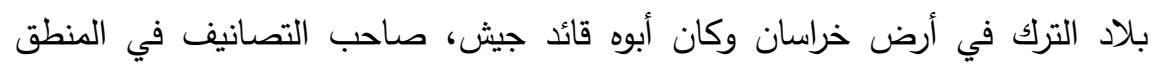
والموسيقى وغيرهما من العلوم، وهو أكبر فلاسفة المسلمين، ولم يكن فيهم من بلغ رتبت ديته

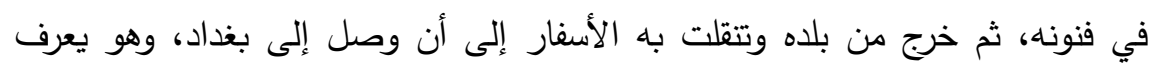

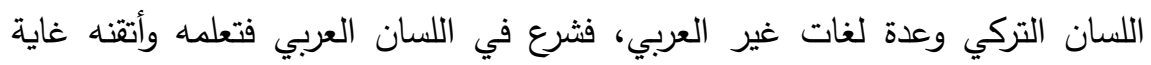

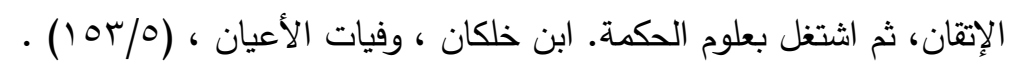

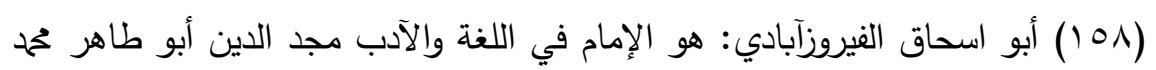

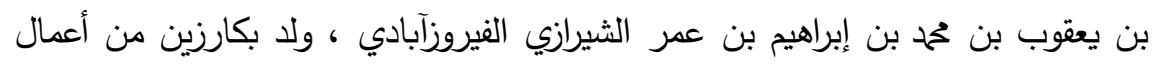

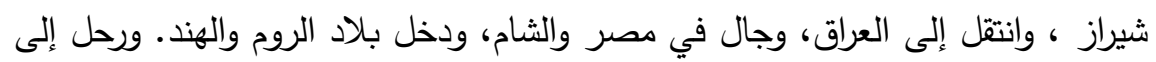

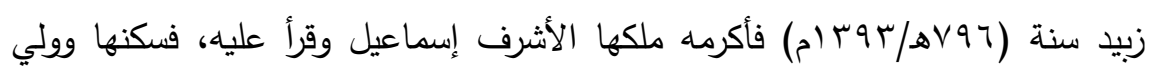
قضاءها، وانتشر اسمه في الآفاق، حتى كان مرجع عصره في اللغة والحديث والتفسير .

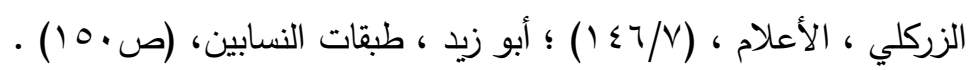

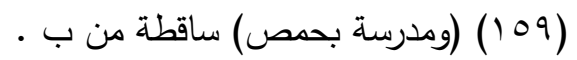

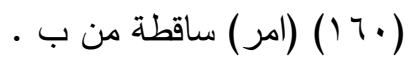

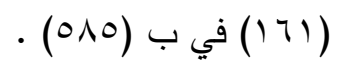

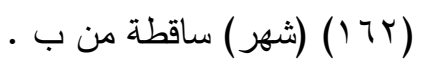

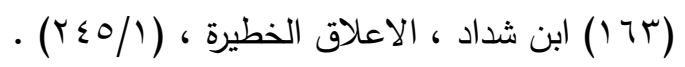

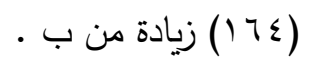


(170) فخر الدين سرخاب بن الحسن بن الحسين الأرموي : هو الفقيه الدتكلم الدفتي

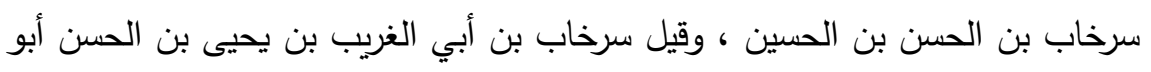

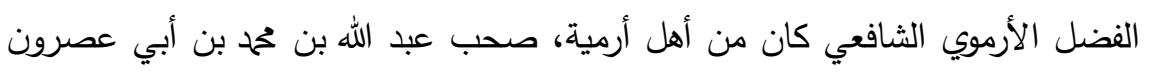

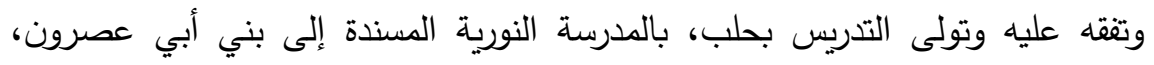

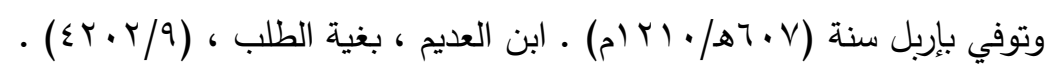

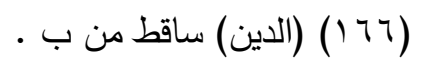

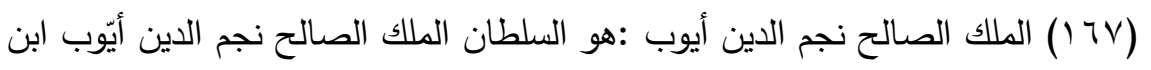

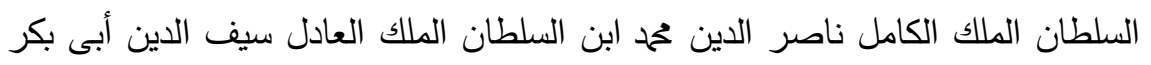

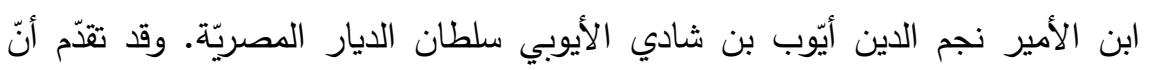

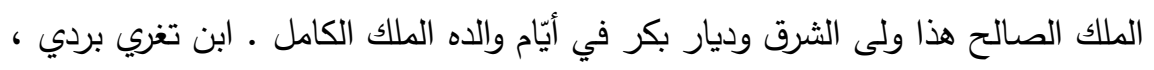

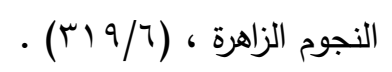

(14 (1) التركي : هو شرف الدين عثمان بن محمد بن عبد الله بن محمد بن عبد الله بن علي

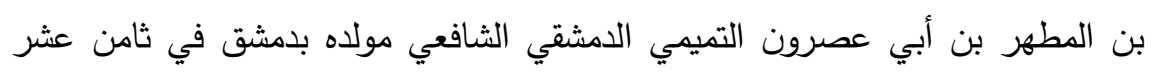

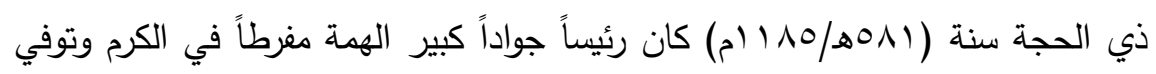

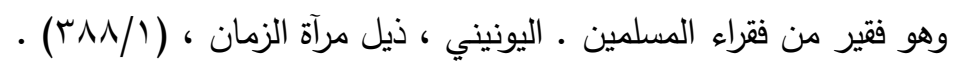

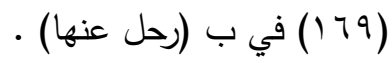

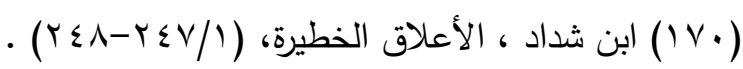

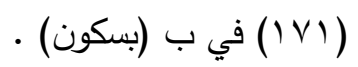

احمد بن الفضل النفري: هو أبو العباس ، حدث بحلب عن القاضي أبي عمران (IVT)

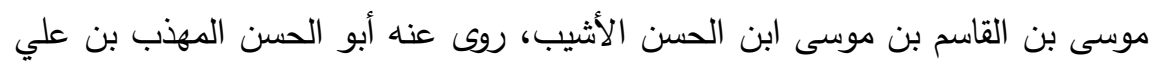

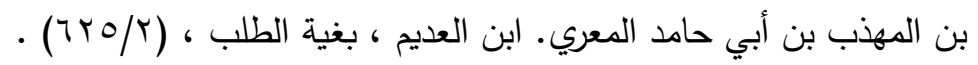

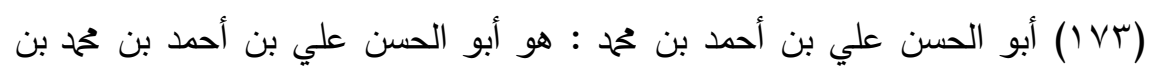

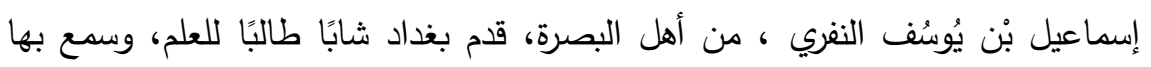

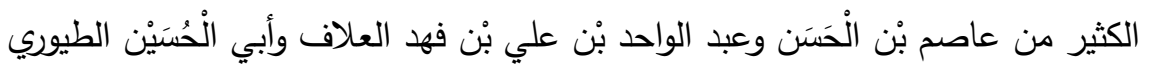

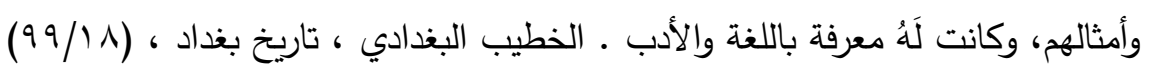




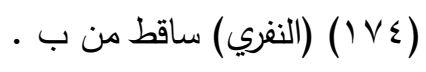

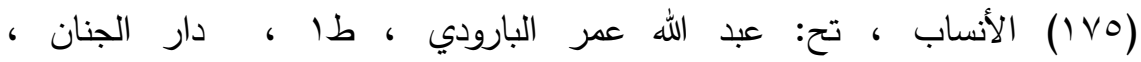

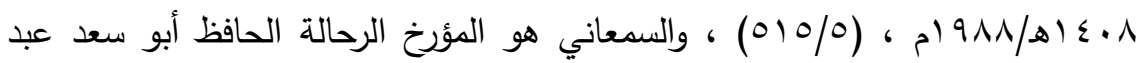

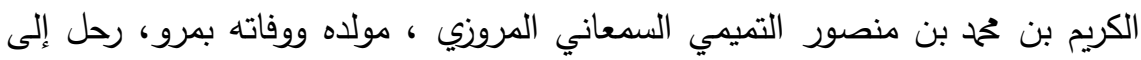

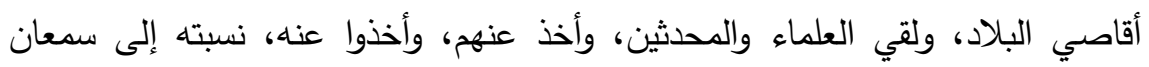

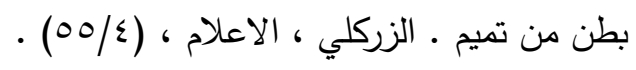

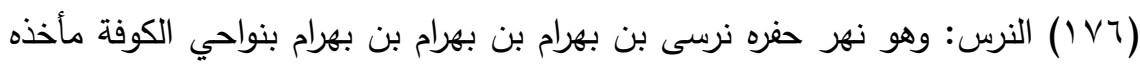

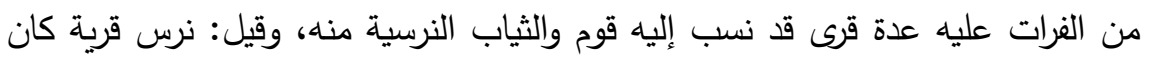

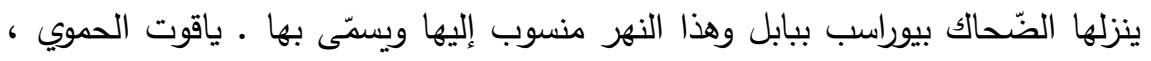

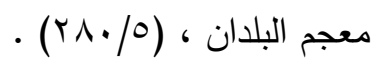
نرسى بن بهرام: وهو أخو بهرام الثالث، فلما عقد التاج على رأسه دخلت عليه (IVV)

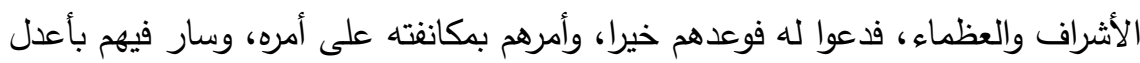

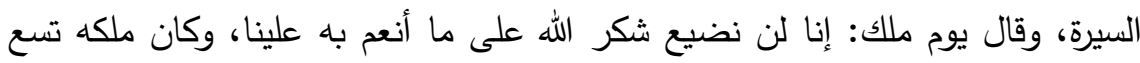

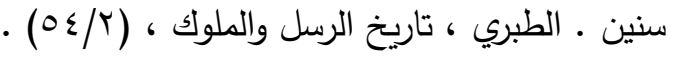

$$
\begin{aligned}
& \text { (ابن عبد الحق ، (IVA) }
\end{aligned}
$$

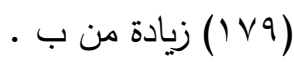

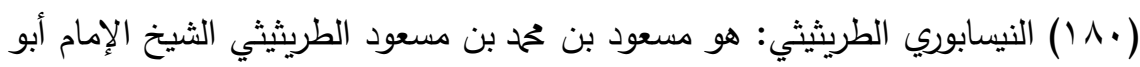

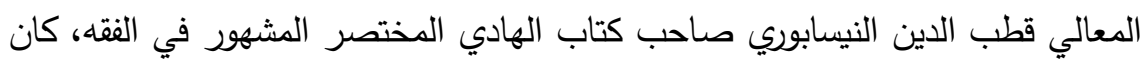

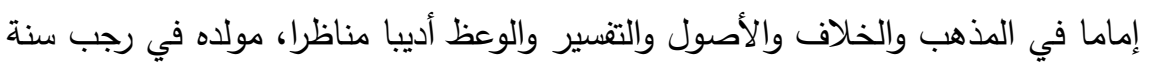

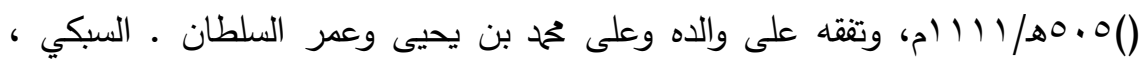

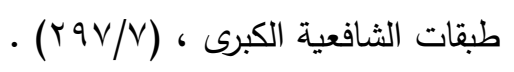

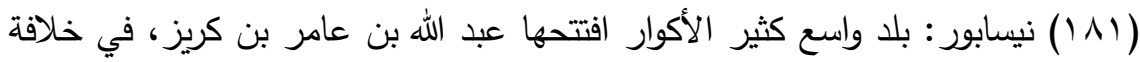

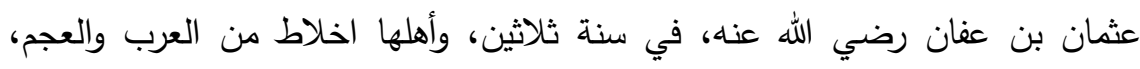

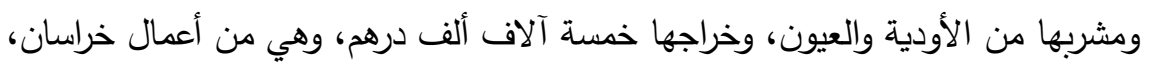

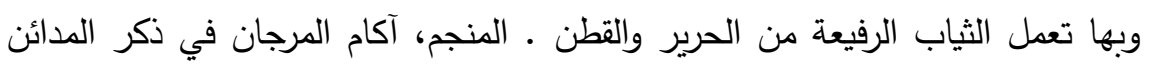

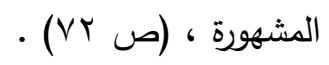




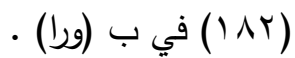

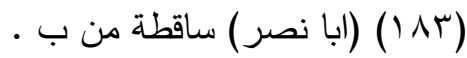

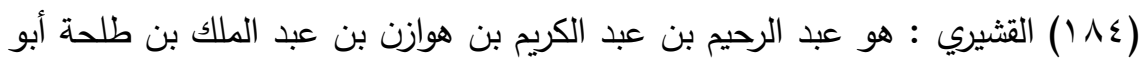
نصر ابن الأستاذ أبي القاسم القثيري من أهل نيسابور كان من أئمة المسلمين وأعلام

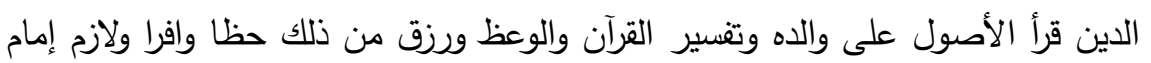

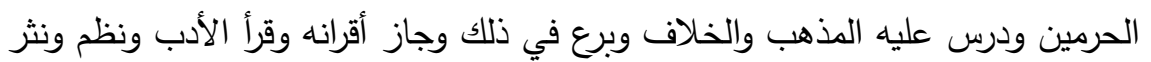
وسمع من إسماعيل بن عبد الرحمن الصابوني وعبد الغافر بن ححمد بن عبد العزيز

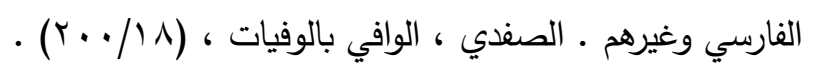

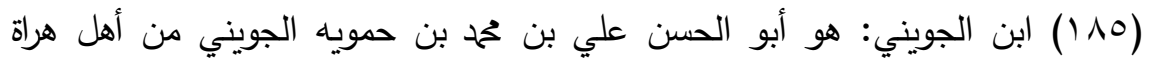

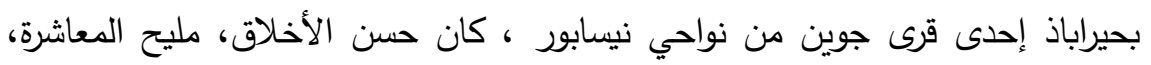

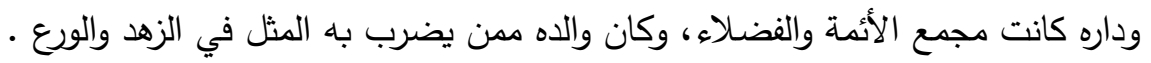

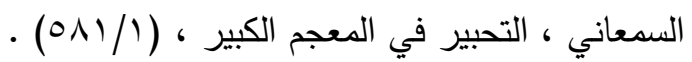
(11) المدرسة المجاهدية: بالقرب من باب الخواصين واقفها الأمير الكبير مجاهد

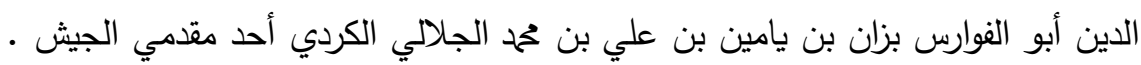

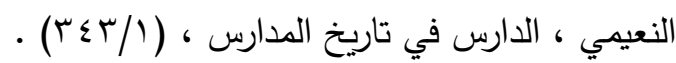
( NVV)

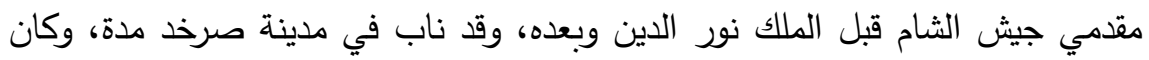

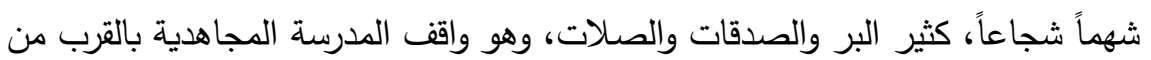

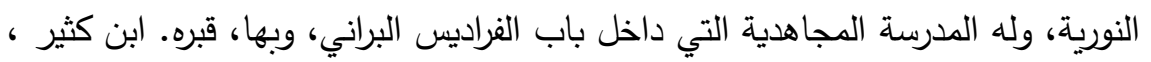

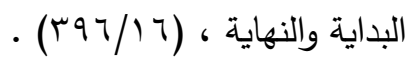

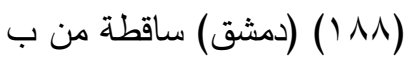

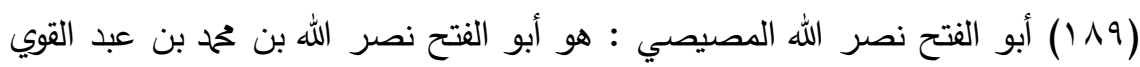

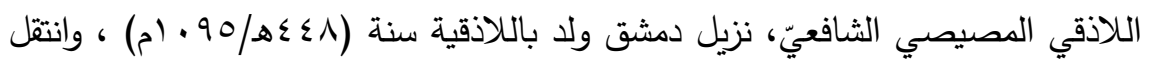

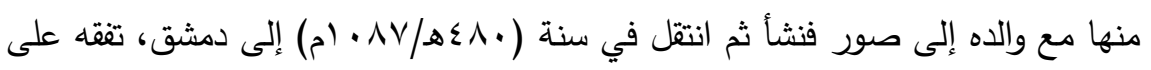

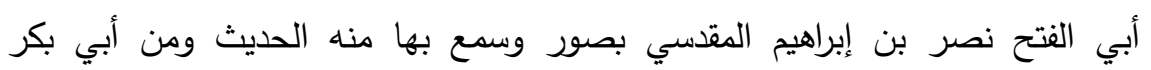


الخطيب وسمع ببغداد وبالأنبار وكان فقيهاً مفتياً متكلماً في الأصول ديناً ، ابن الجوزي

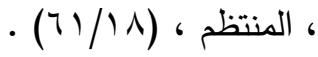

$$
\begin{aligned}
& \text { (19. (19) في ب (كانت) . (19) } \\
& \text { (191) في ب (للتكلف) . } \\
& \text { (19 1) في ب (ظاهر) . }
\end{aligned}
$$

(9r (19) ابن جهبل : هو الفقيه الثافعي مجد الدين طاهر بن نصر الله، ابن جهبل الحلبي ، هو أول من درّس بالمدرسة الصلاحية بالقدس ، وهو والد بني جهبل الفقهاء

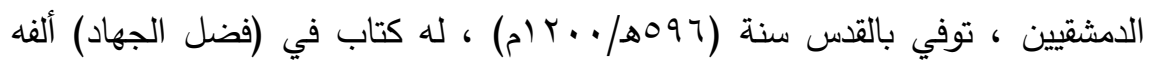

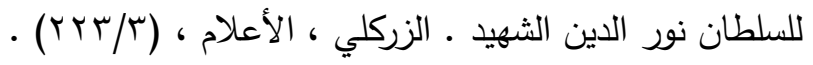

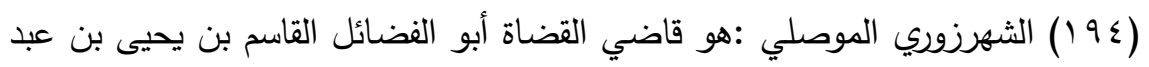

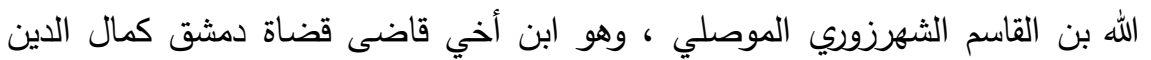

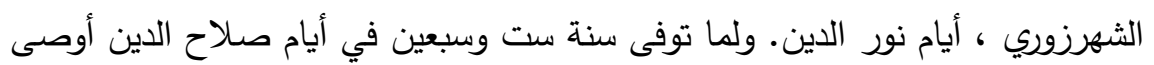

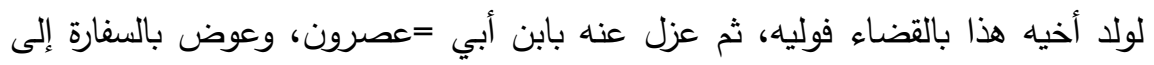

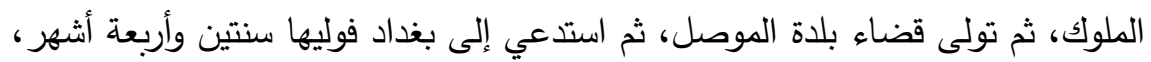

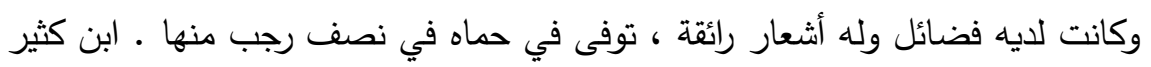

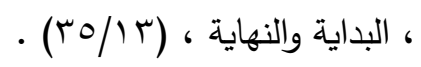

$$
\text { (97 (190) في ب (197) في ب (وقدم) (197) }
$$

(19V) ابن أبي الحجاج العدوي الدشقي: هو قاضي حلب الفقيه الفاضل أبو المكارم

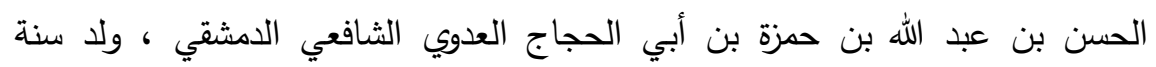

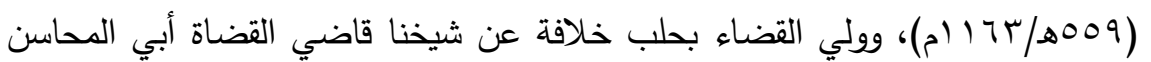

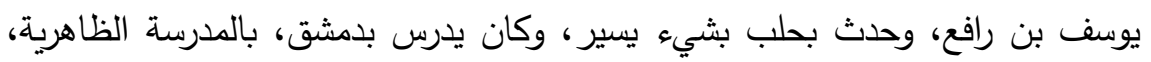

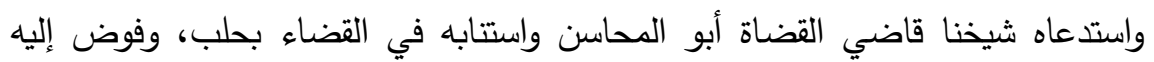

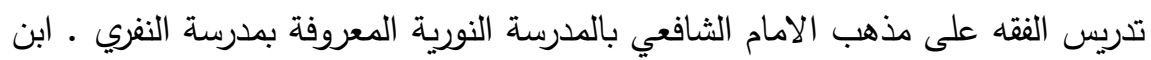

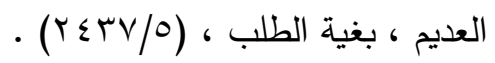

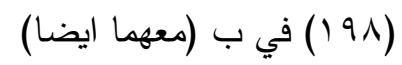




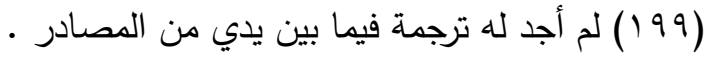

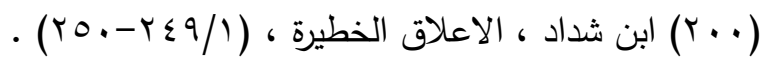

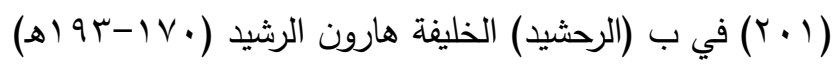

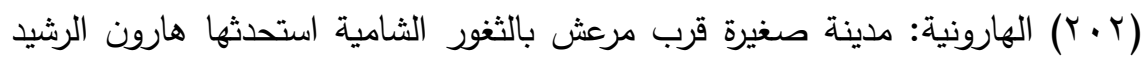

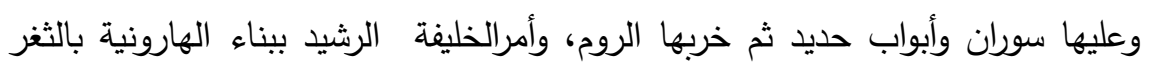

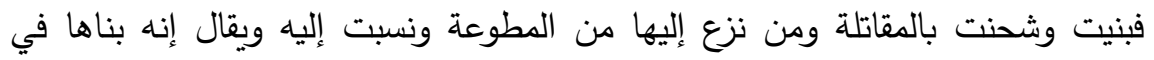

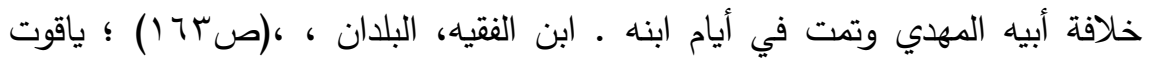

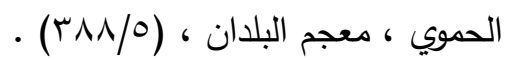

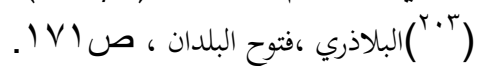

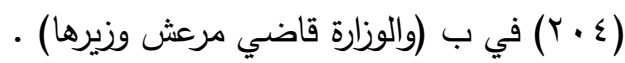

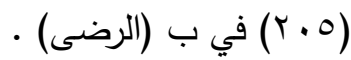

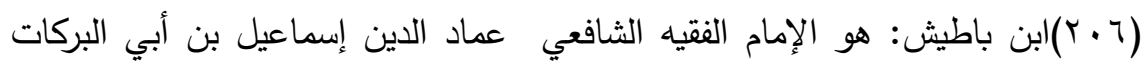

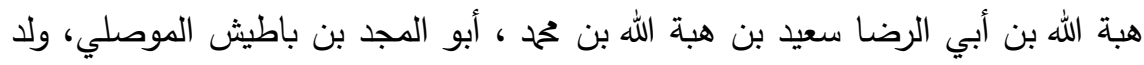

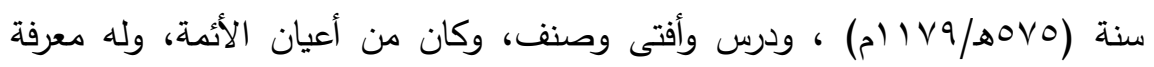

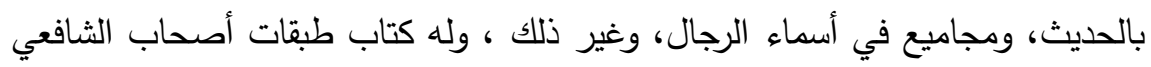

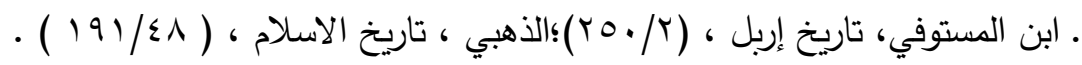

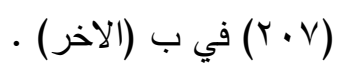

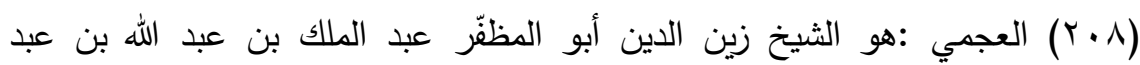

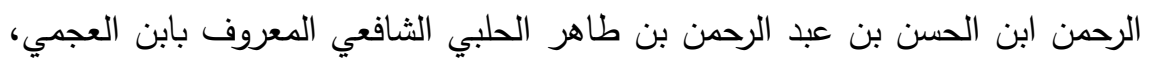

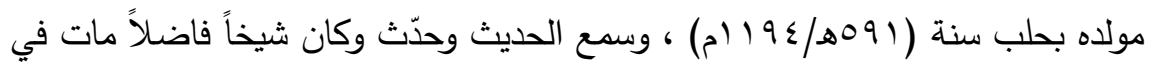

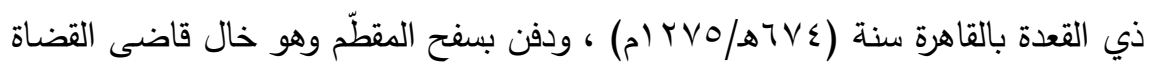

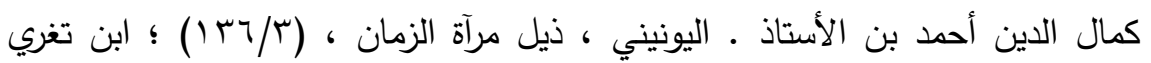

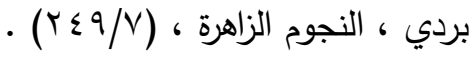

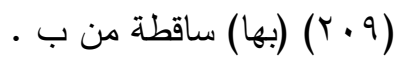

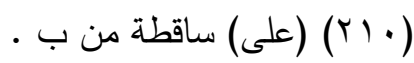


(Y) (Y) (Y) الدين الدين الأسدي: هو القاضي زين الدين عبد الله بن عبد الرحمن بن عبد الله

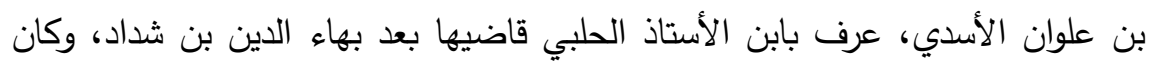

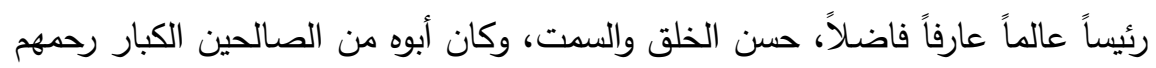

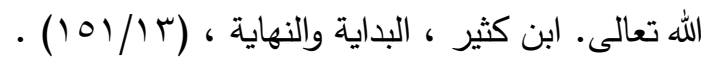

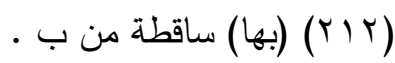

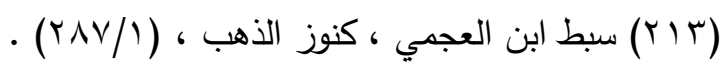

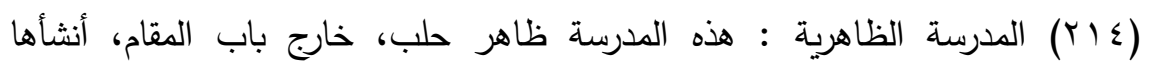

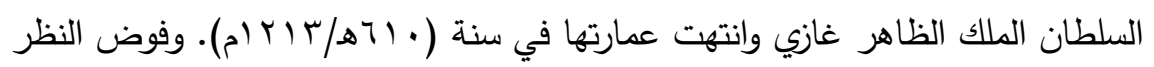

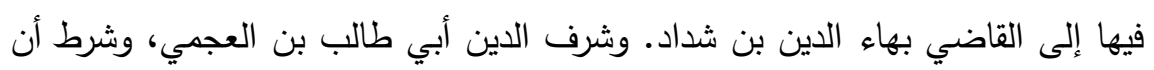

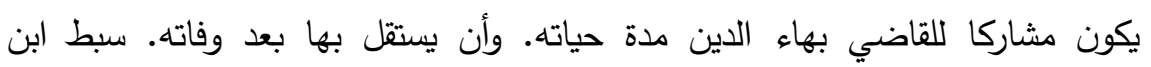

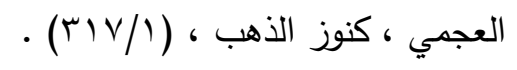

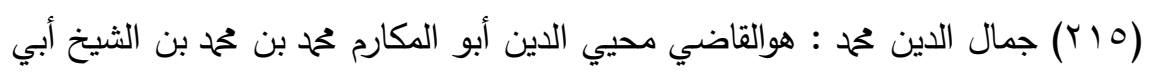

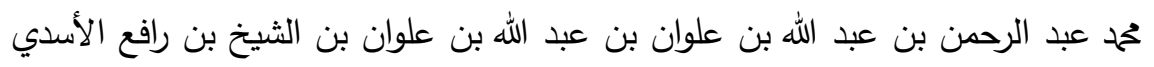

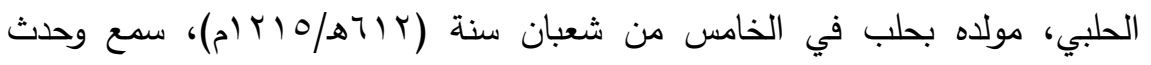
ودرّس بالمدرسة المسرورية بالقاهرة، ثم تولى القضاء بحلب إلى حين وفاته، وبيته

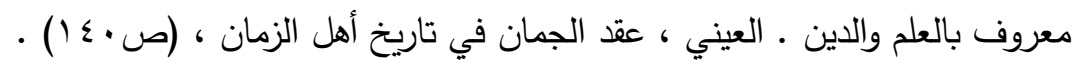

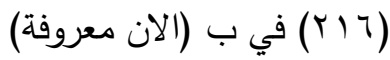

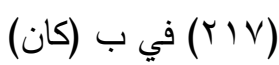

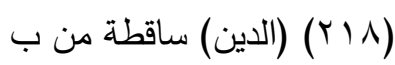

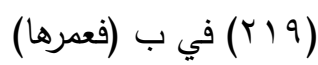

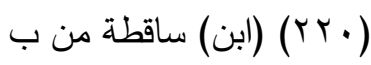

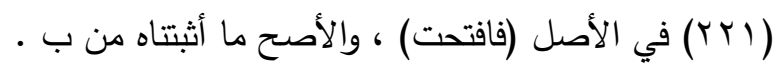

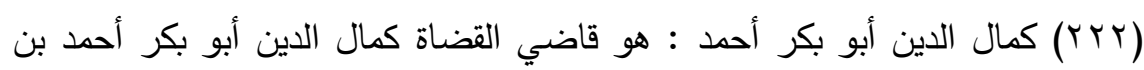

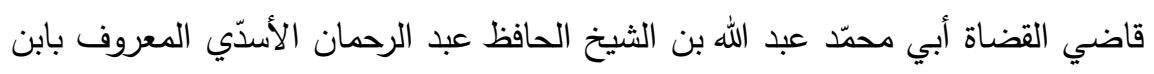

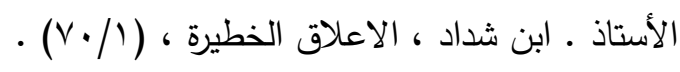

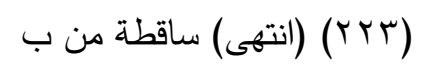




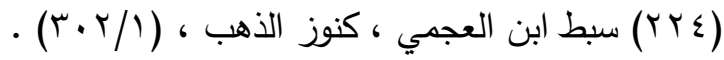

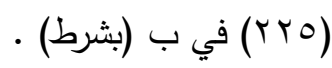

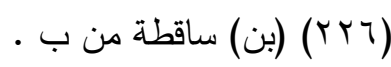

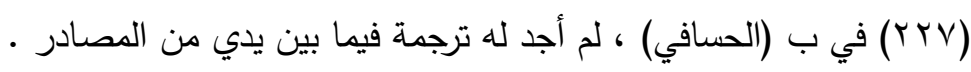

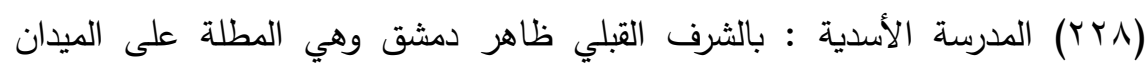

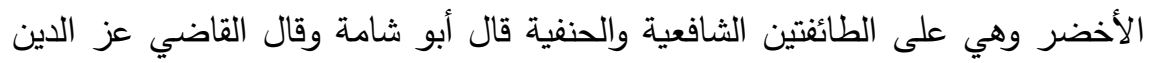
بن شداد في كتابه الأعلاق الخطيرة: المدرسة الأسدية على الفريقين أنشأها أسد الدين الطين

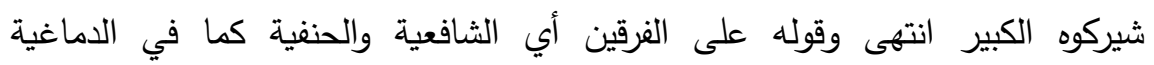

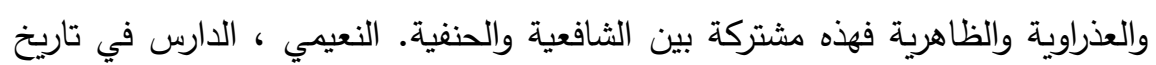

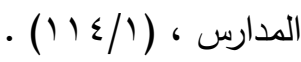

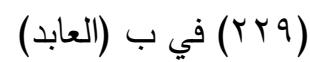

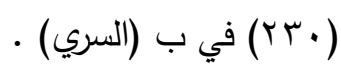

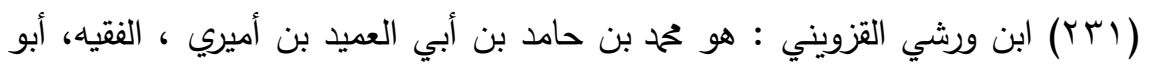

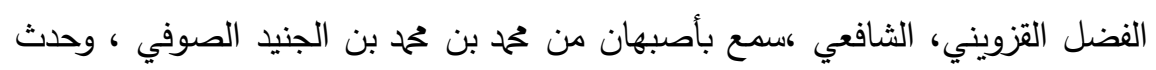

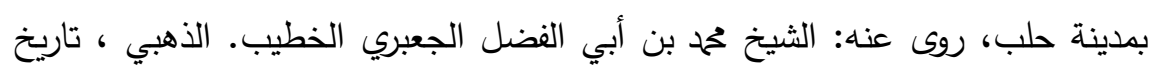

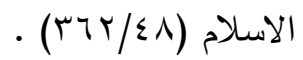

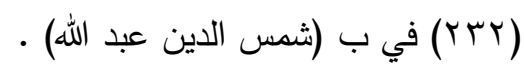

(الر (YT) الكثوري : فتح الكاف، وقيل بالكسر ، والواو بينهما الثين المعجمة وفي آخرها

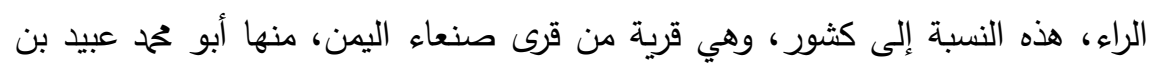

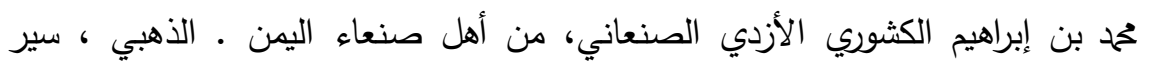

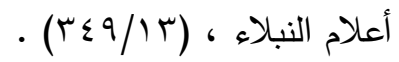

$$
\begin{aligned}
& \text {. }
\end{aligned}
$$

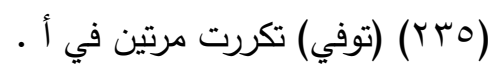

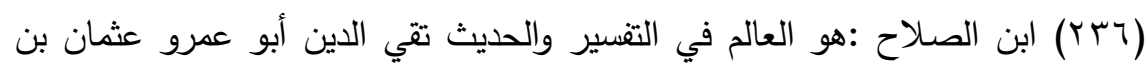

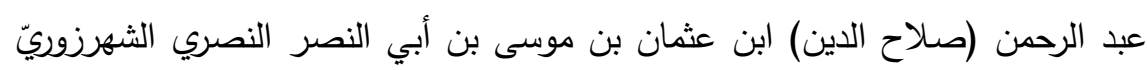

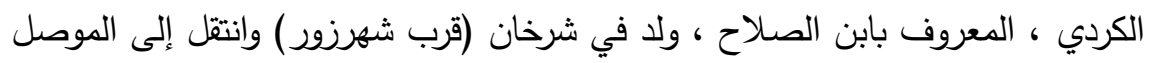


ثم إلى خراسان ، فبيت المقدس حيث ولي التدريس في الصلاحية ـ الزركلي ، الأعلام ،

$$
\begin{aligned}
& \cdot(r \cdot V / \varepsilon) \\
& \text {. (الدين) ساقطة من ب (YrV) }
\end{aligned}
$$

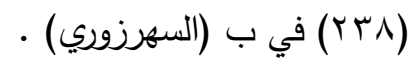

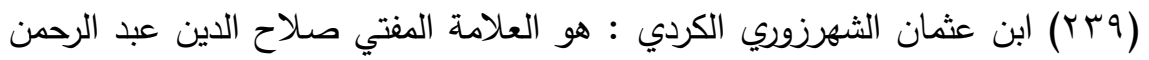
بن عثمان بن موسى الكردي الثهرزوري الثافعي، والد الثيخ تقي الدين أبي عمرو بن الثنان الثين

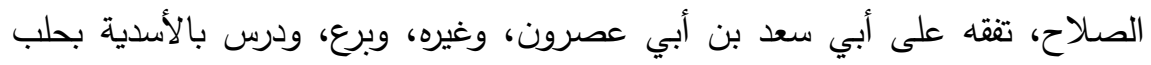

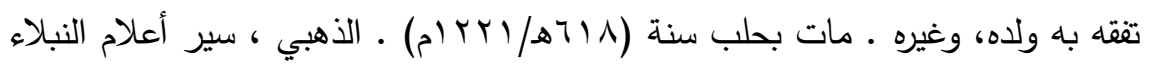

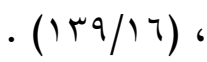

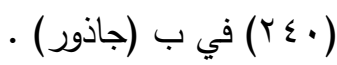

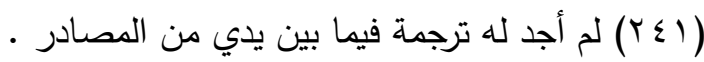

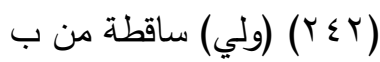

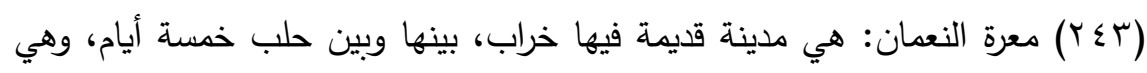

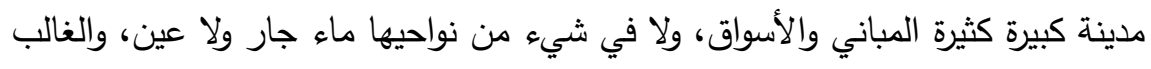

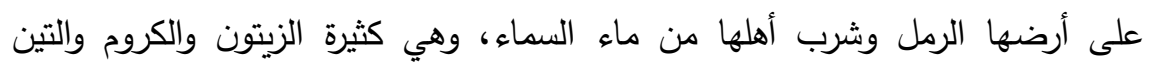

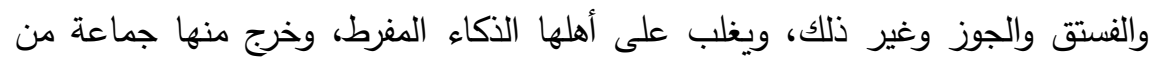

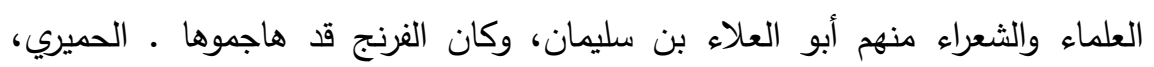

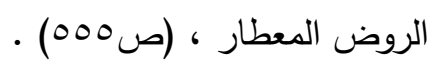

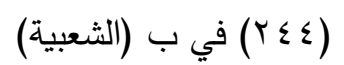

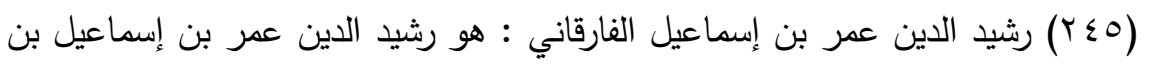
مسعود الفارقي الثافعي، مدرس الظاهرية، توفي بها وقد جاوز التسعين، وجد مخنوقا في المحرم، ودفن بالصوفية، وقد سمع الحديث وكان منفردا في فنون من العلوم كثيرة، منها

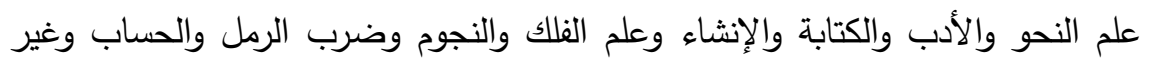

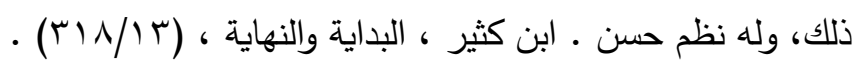

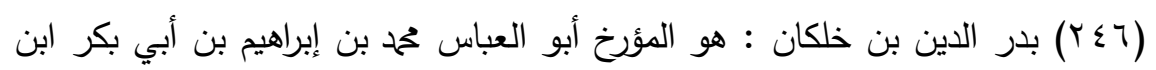

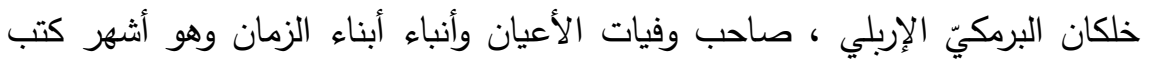


التراجم ومن أحسنها ضبطاً وإحكاماً، ولد في إربل ، وانتقل إلى مصر فأقام فيها مدة،

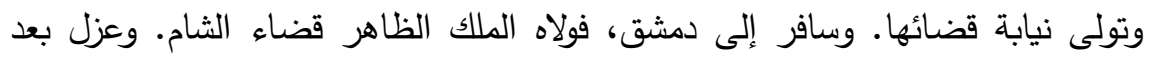

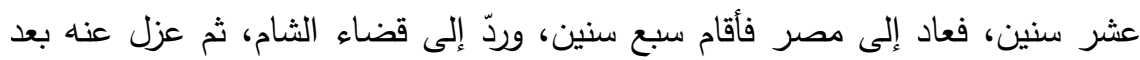
مدة. وولي التدريس في كثير من مدارس دمثق، وتوفي فيها ودفن في سفح قاسيون ،

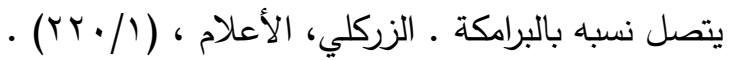

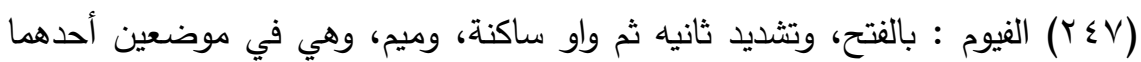

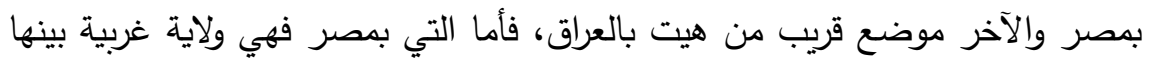

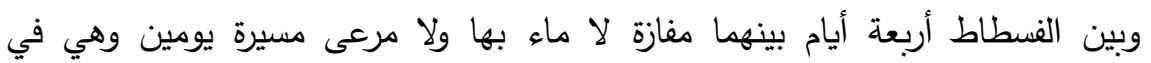

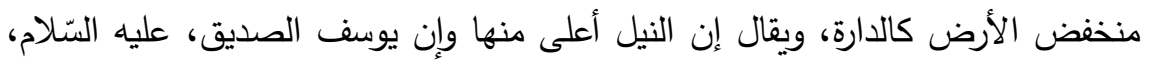
لما ولي مصر ورأى ما لقي أهلها في تلك السنين المقحطة اقتضت فكرته أن حفر نهرا

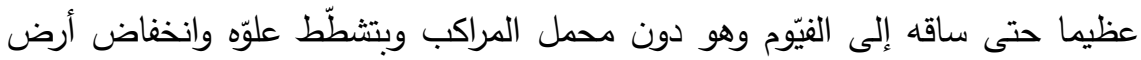

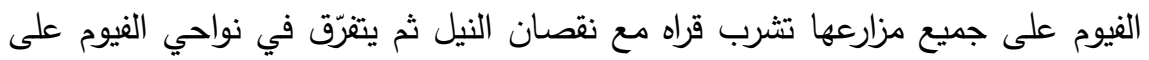

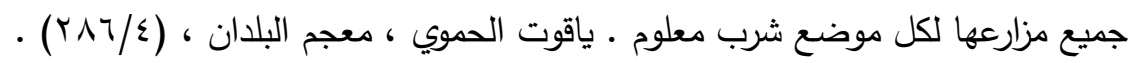

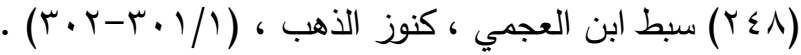

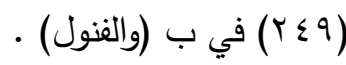

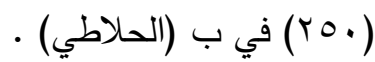

(Y01) علاء الدين بن الخطيب : هو القاضي علي بن عبد الرحمن بن الحسين

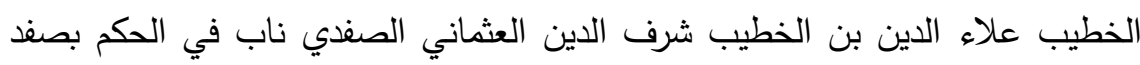
وخطب بها ودرس وقام بالفتوى بعد ابن الرسام وله مختصر في الفقه سماه النافع مات

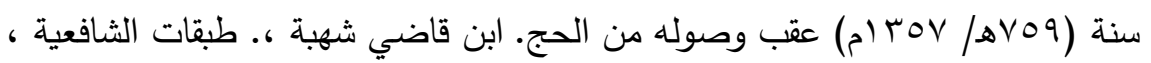
$\cdot(r V / T)$ )

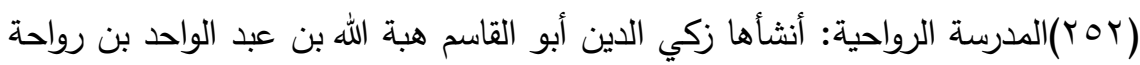

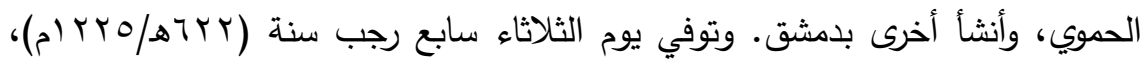

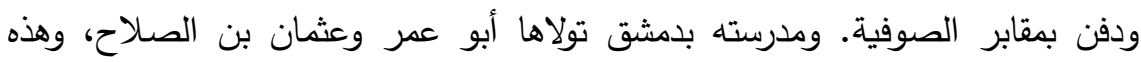

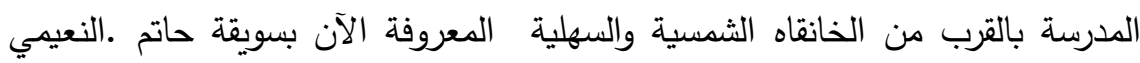

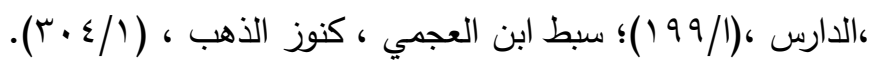




$$
\text { • (كم) (r०r) }
$$

(Y0) الحموي: هو زكي الدين أبو القاسم هبة الله بن محمد الأنصاري المعروف بابن

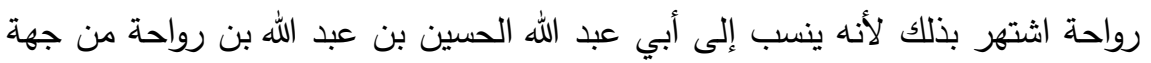

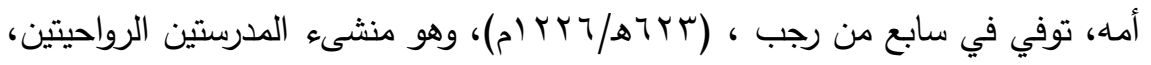

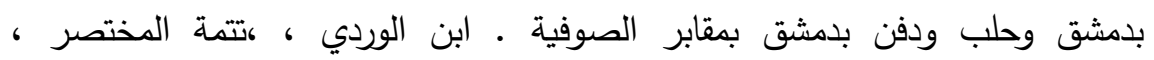

$$
\begin{aligned}
& \text {. ( }(\leqslant r / r)
\end{aligned}
$$

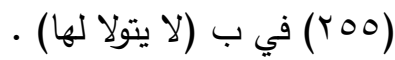

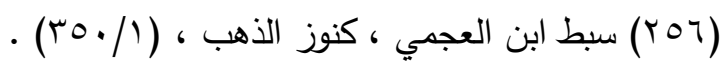

(Yor)

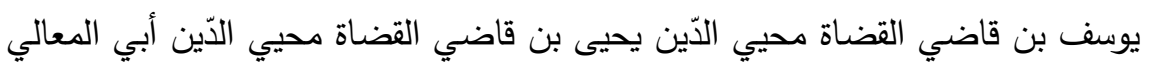

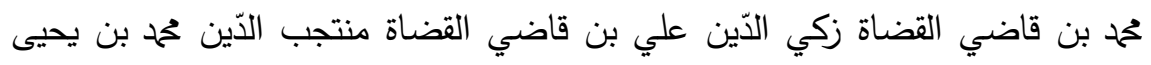

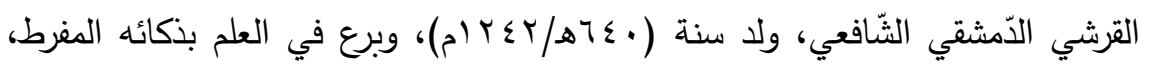
وقدرته على المناظرة وحلّ المعضلات. وسمع بمصر من جماعة، وتفقه بأبيه وغيره،

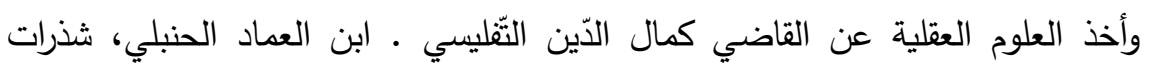

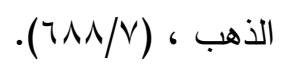

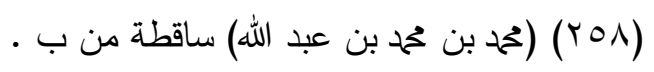

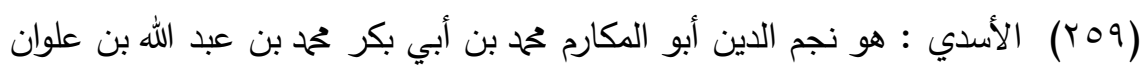

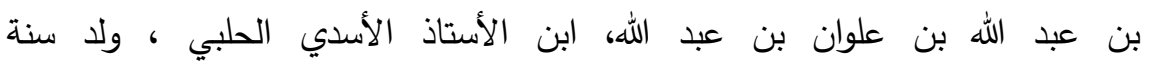

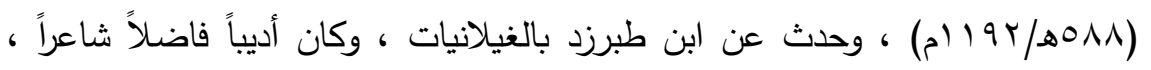

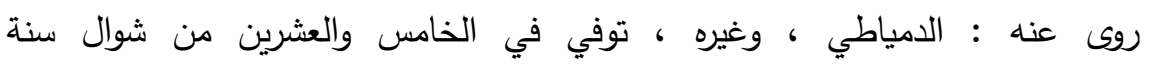

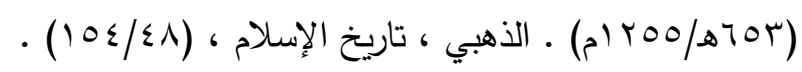

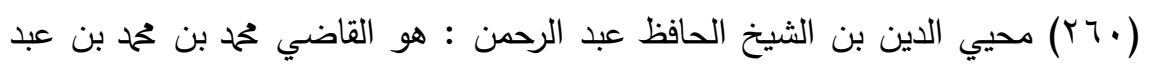

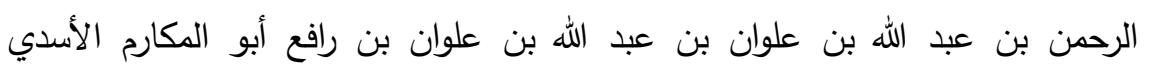

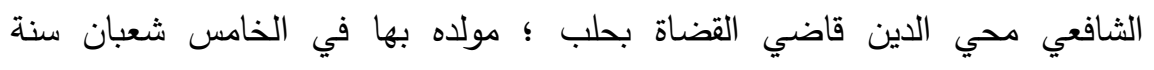

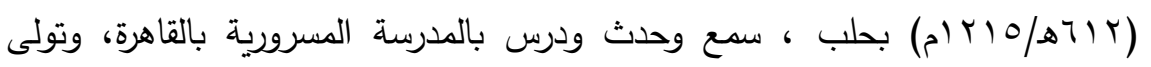
القضاء بحلب وأعمالها إلى حين وفاته ؛ وبيته معروف بالب ، بالعلم والدين والتقدم والسنة 


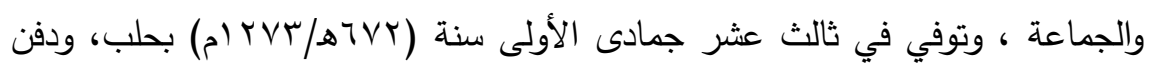

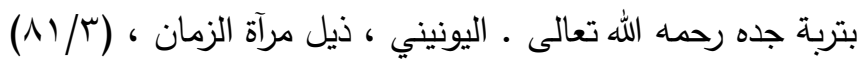

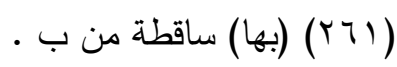

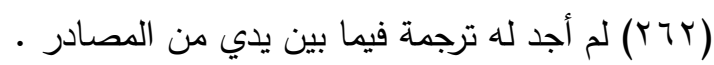

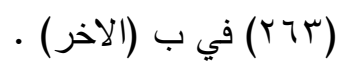

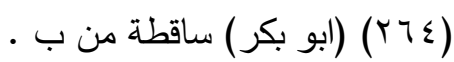

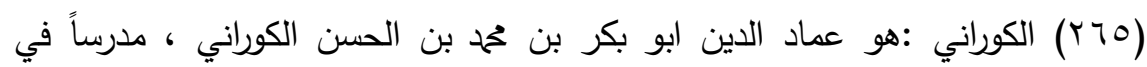

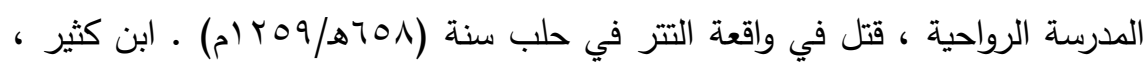

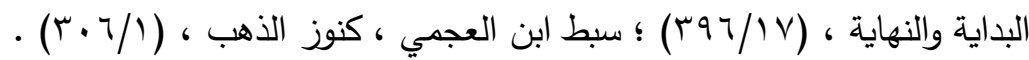

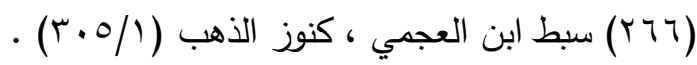

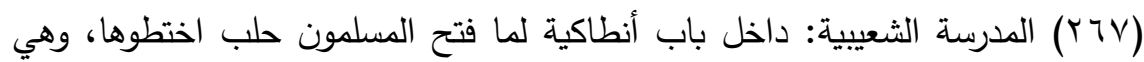

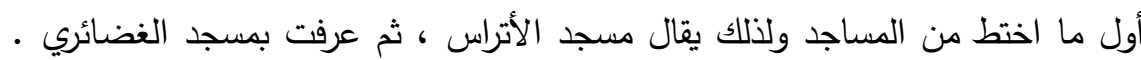

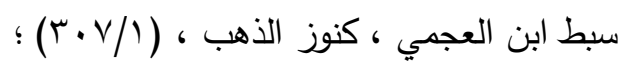

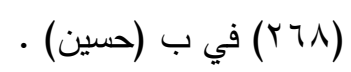

(Y79) الأندلسي :هو أبو مدين المغربي شعيب بن الحسين أبو مدين الأندلسي الزاهد

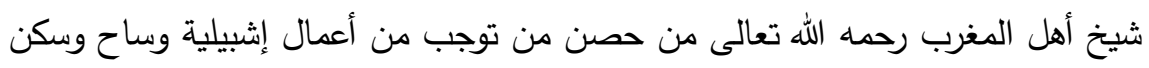

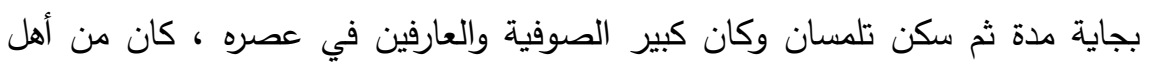

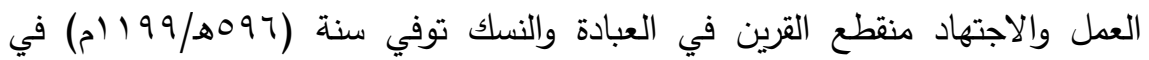
طريق مكة، ودفن بين تيماء وبين جفر بني عنزة؛ وكان من الفقهاء المعتبرين، والزهاد

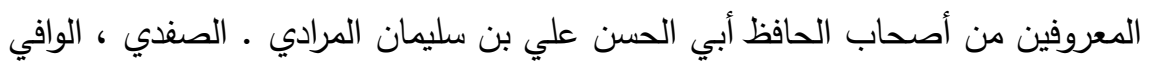

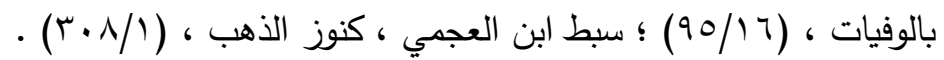
• (لهاء) (YV•)

تيماء: بلدة في أطراف الثام، بين الثام ووادي القرى، على طريق حاج الثام (YV)

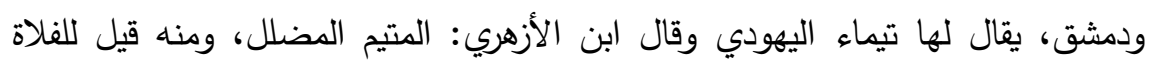

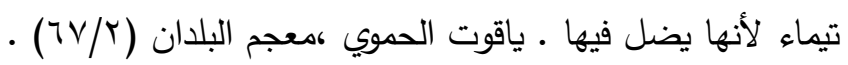


أبو الحسن علي بن سليمان المرادي : وقيل الثقوري الفرغليطي الفقيه الثافعي (YVY)

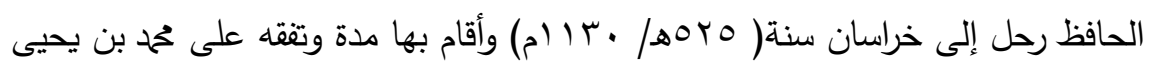

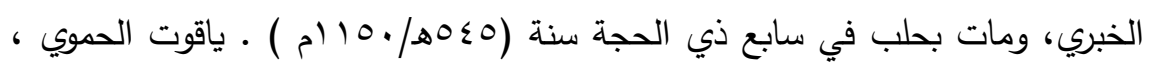

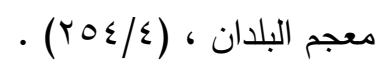

الثيخ موفّق الدين أبو القاسم بن عمر بن فضل الكُرْديّ الحُمَيديّ : درس في (rVT)

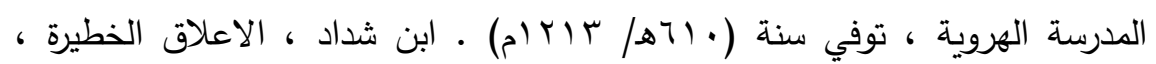

$$
\begin{aligned}
& \text {. (rT)/1) }
\end{aligned}
$$

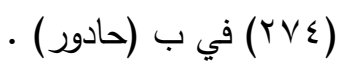

(بV0)

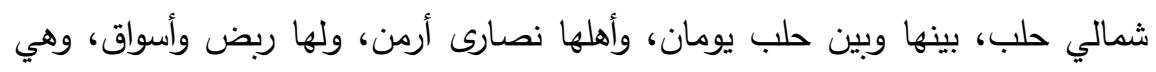

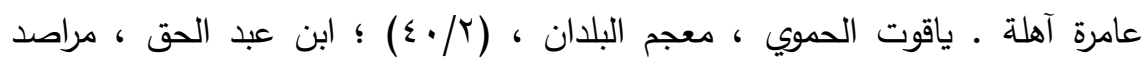

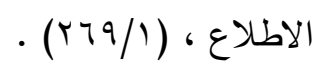

(المدرسة الثرفية: أنشأها الثيخ الإمام شرف الدين أبو طالب عبد الرحمن بن

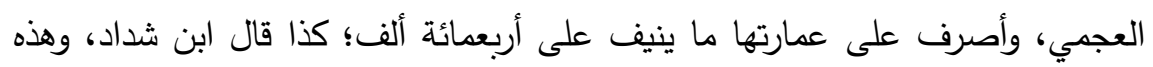

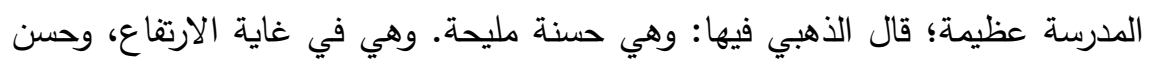

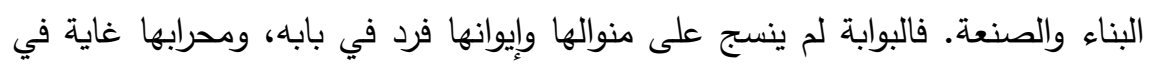

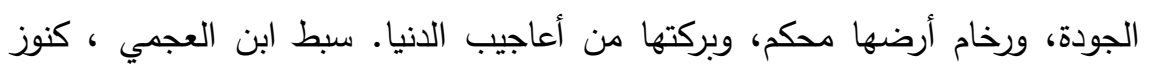

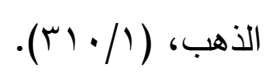

عبد الرحمن بن عبد الرحيم بن أبي طالب عبد الرحمن بن الحسن الكرابيسي:هو (YVV)

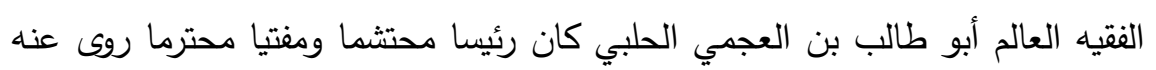

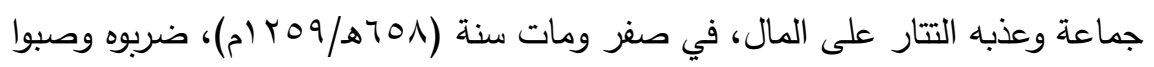

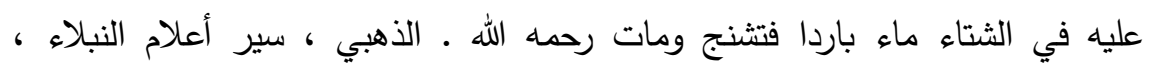
( ) (

$$
\text { • في ب (واصرف) (YVA) }
$$

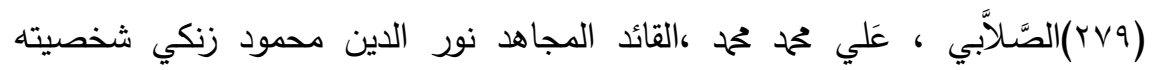

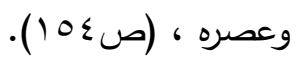


المدرسة البدرية: قبالة الثبلية التي بالجبل عند الجسر المعروف بجسر كحيل (YA. ) ثم بجسر الثبلية وفي كلام ابن كثير أنها جعلت في حدود الأربعين وسبعمائة جامعا فيه خطبة ويوم جمعة ووقفها نصف حمام بقرية مسنون والبستان بقرب جسر كحيل كذا رايته

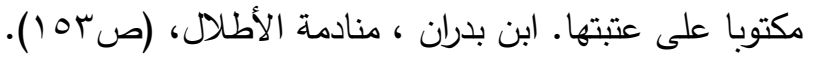

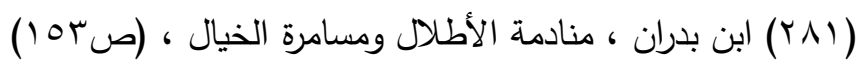

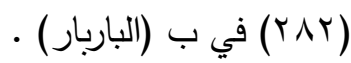

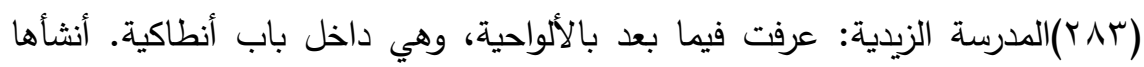

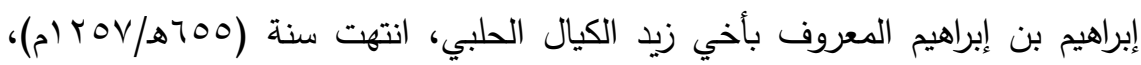
ودرس فيها شمس الدين أحمد بن محيي الدين تحمد بن أبي طالب بن العجمي. وعليه

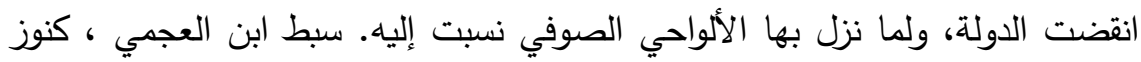

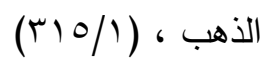

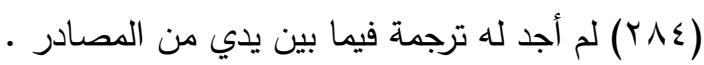

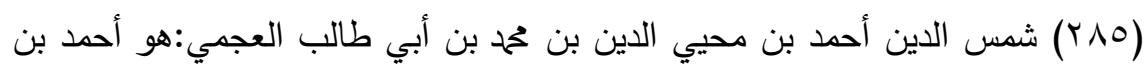

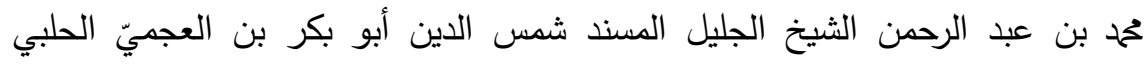

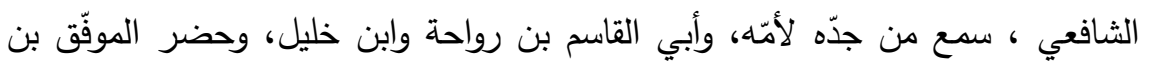

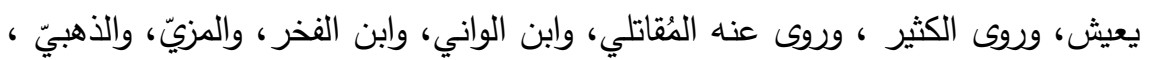

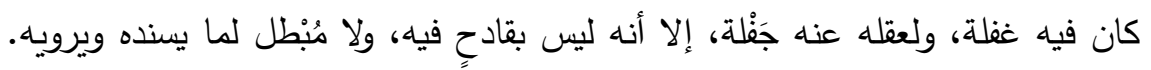

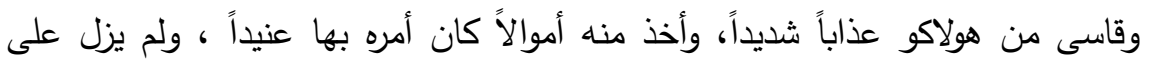

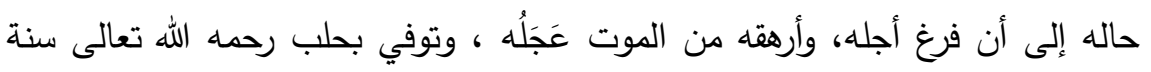
( . $(r \leqslant \varepsilon / 1)$

(T) (YN)(المدرسة السيفية: هذه المدرسة غربي خندق القلعة، أنثأها الأمير سيف الدين

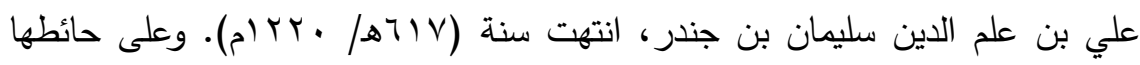

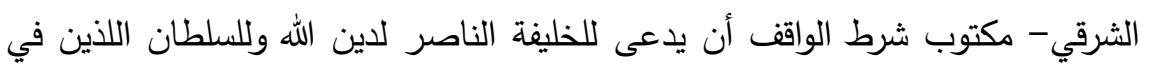

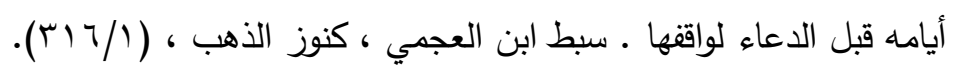


سيف الدين علي بن علم الدين سليمان بن جندر : كان كثير الصدقات، توفي (YN)

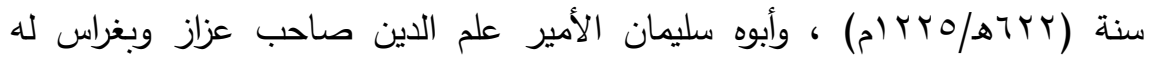

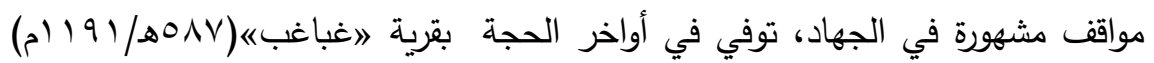
وهو الذي وقف المدرسة بالحاضر اتجاه المسجد الجامع على أصحاب أبي حنيفة .

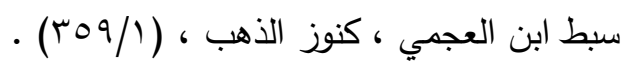

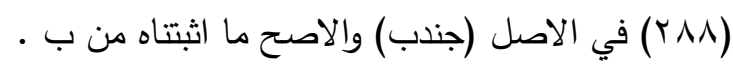

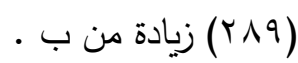

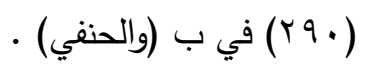

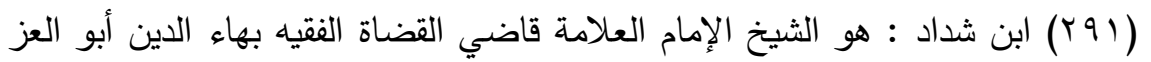

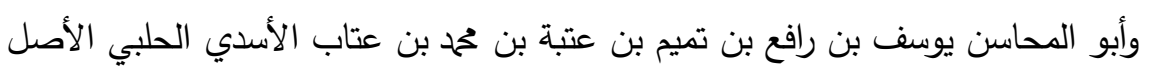

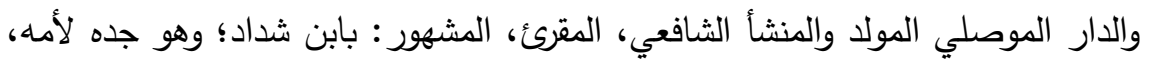

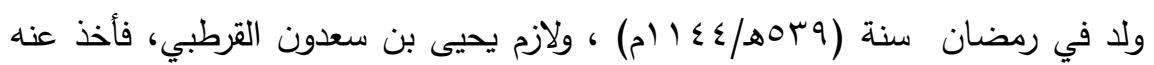

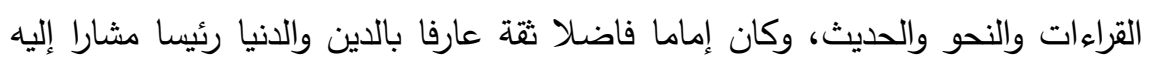

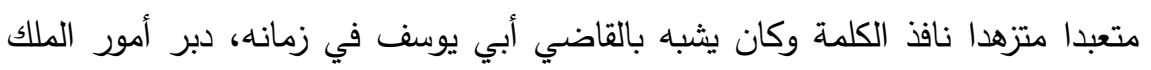

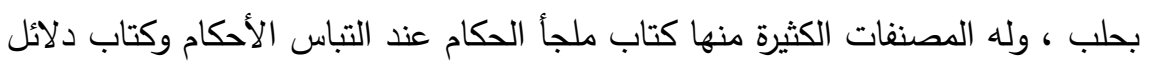

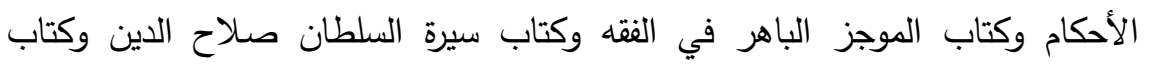

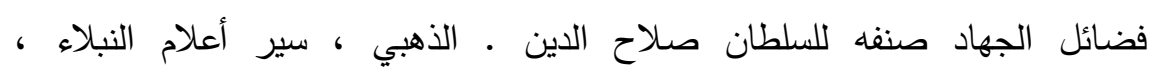

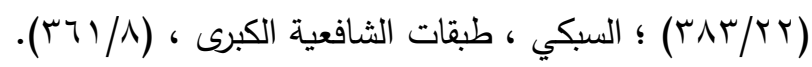

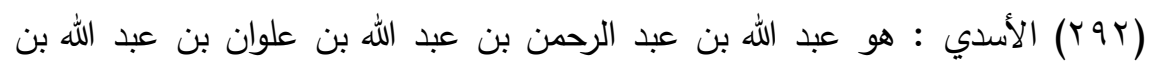

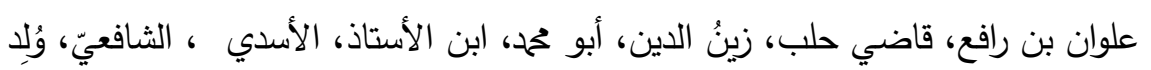

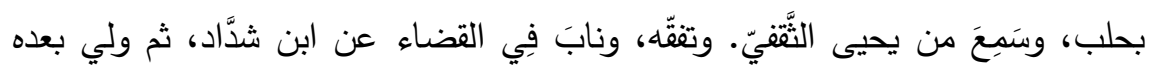

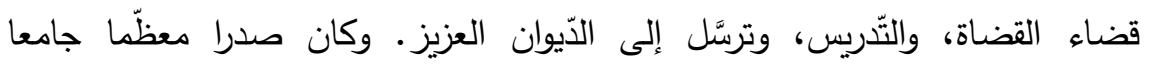

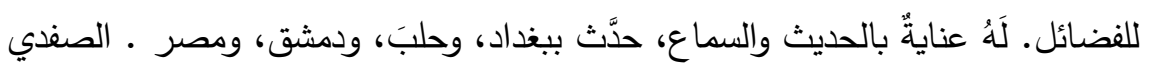

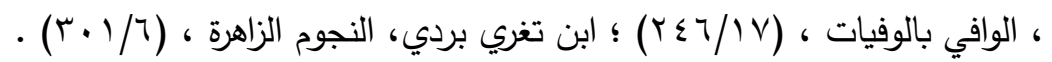

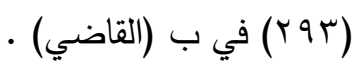

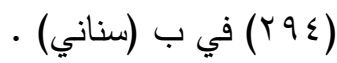




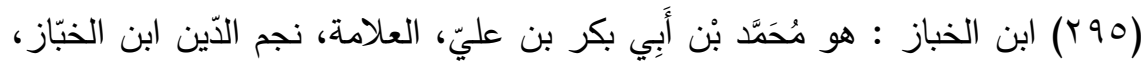

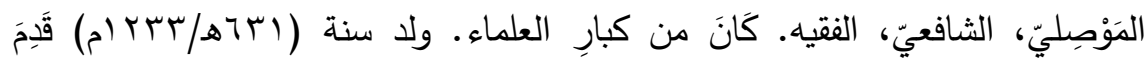

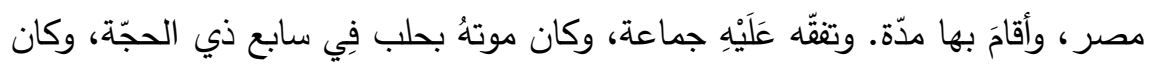

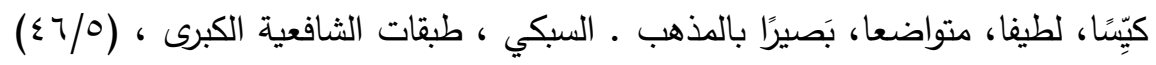

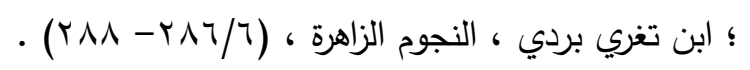

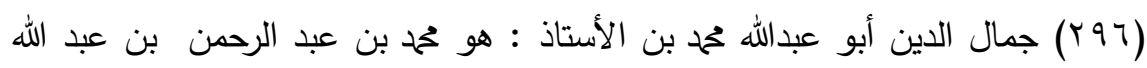

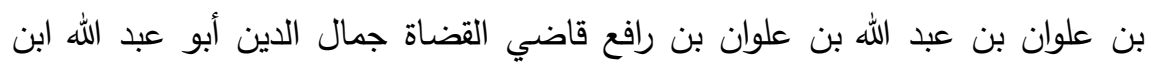

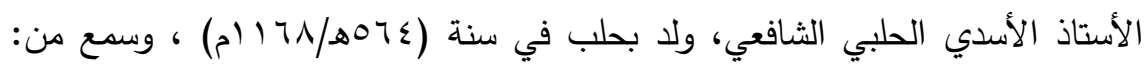

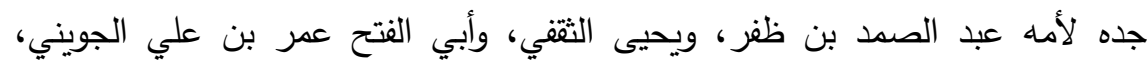

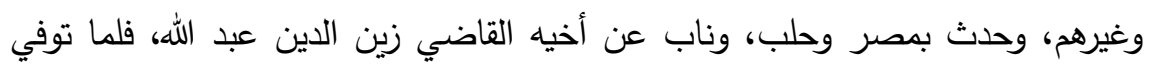

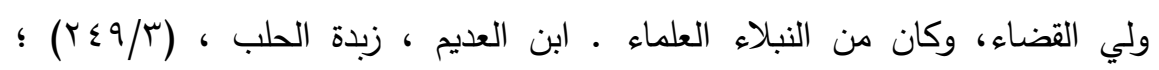

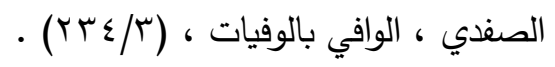

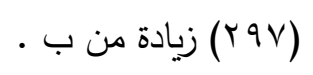

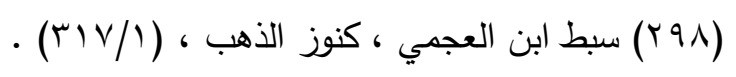

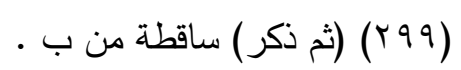

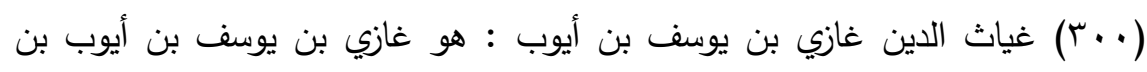

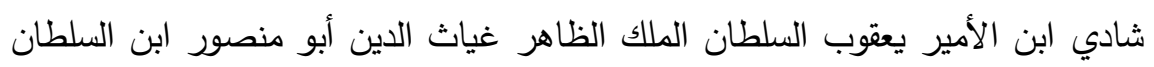

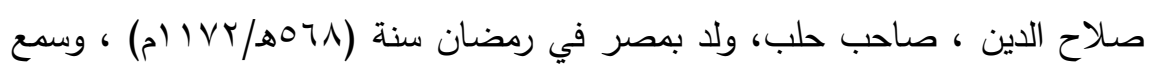
بالإسكندرية من الفقيه أبي الطاهر بن عوف، وبمصر من ولد عبد الله بن بري النحوي،

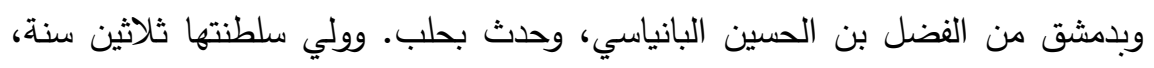

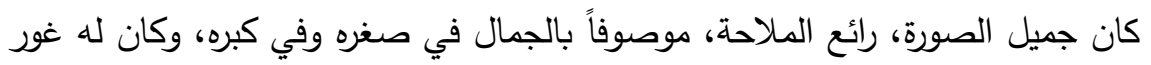

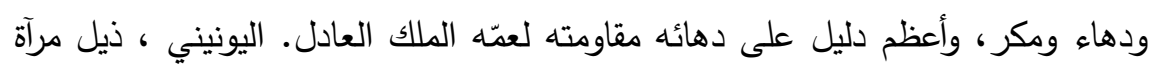

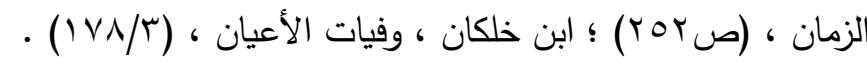

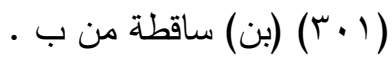

$$
\begin{aligned}
& \text { (r) (r) في ب (بره) }
\end{aligned}
$$




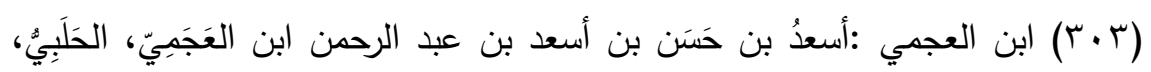

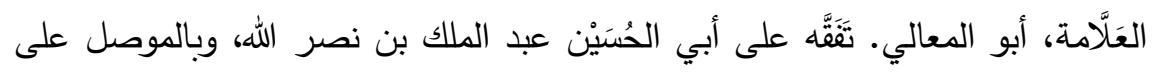

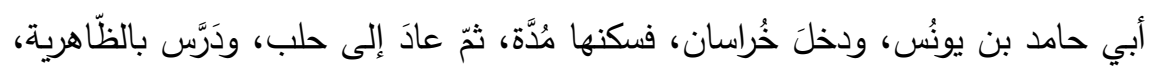

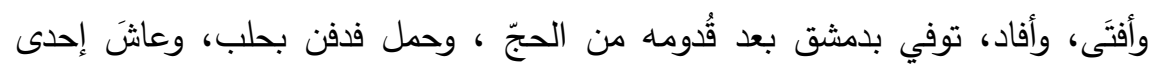

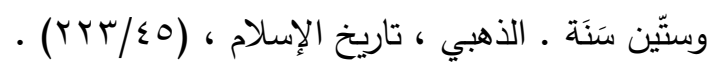

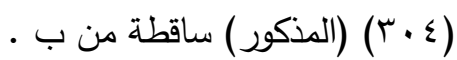

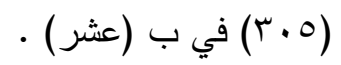

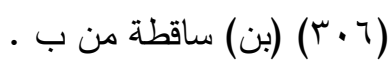

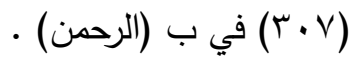

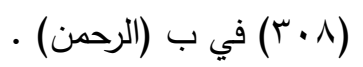

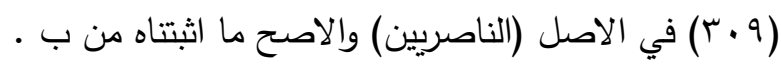

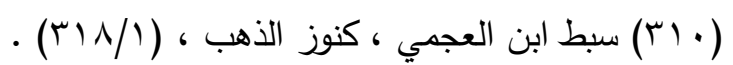

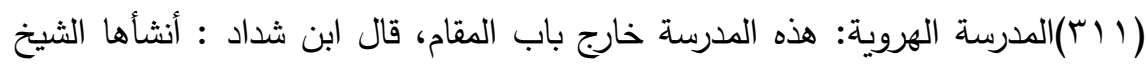

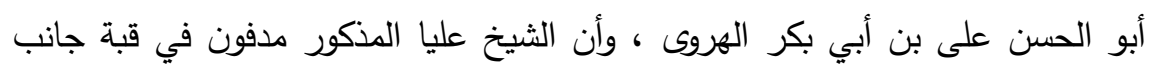

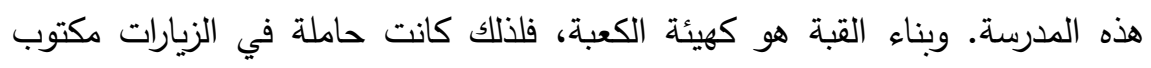
عليها: حكم ومواعظ وبها بئر من خارجها تتسب إلى سيدنا الخليل عليه السلام. وقد قال

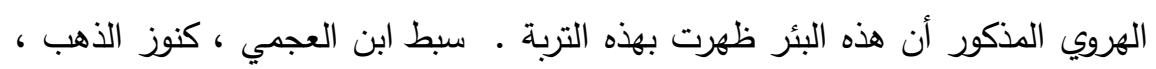
. ( $19 / 1)$

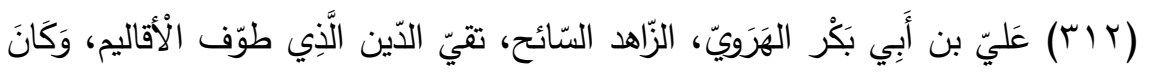

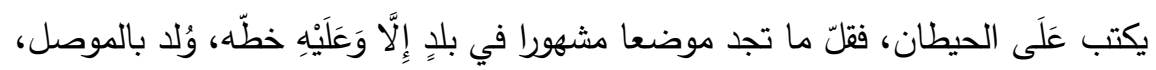

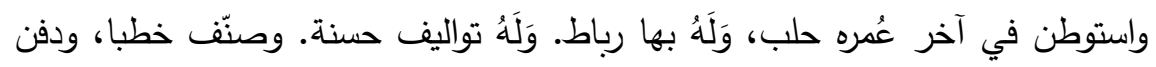

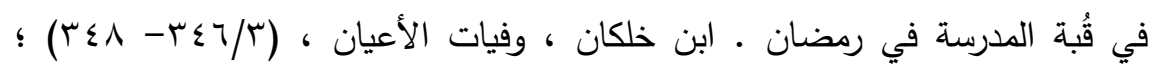

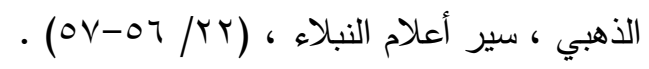

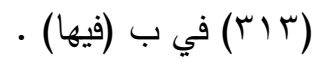

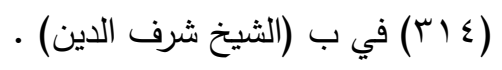


(10) الامام شمس الدين أبو المظفر حامد بن أبي العميد بن أميري بن ورشي بن

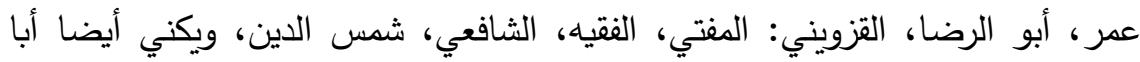

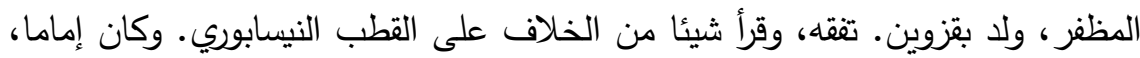

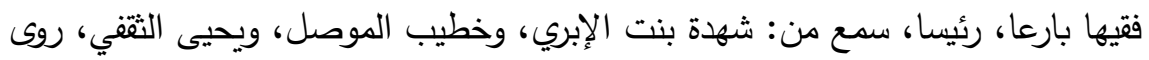

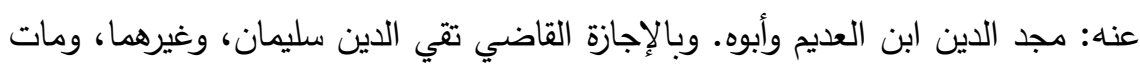

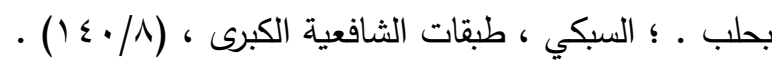

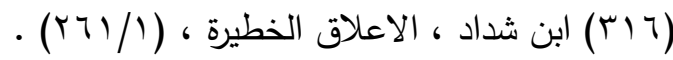

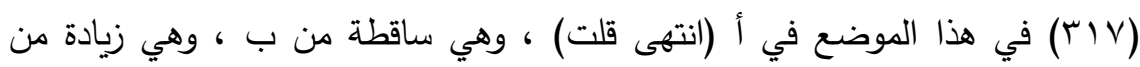

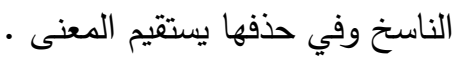

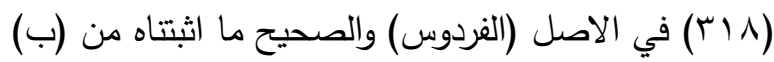

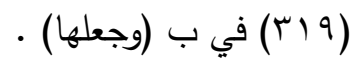

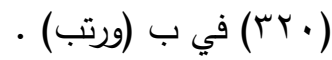

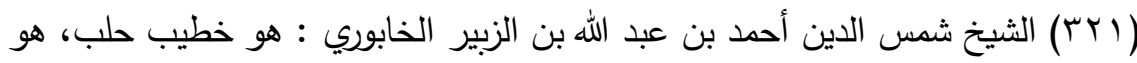

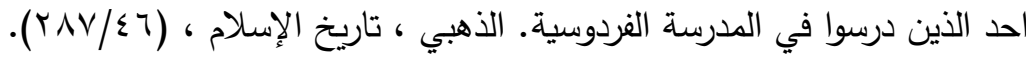

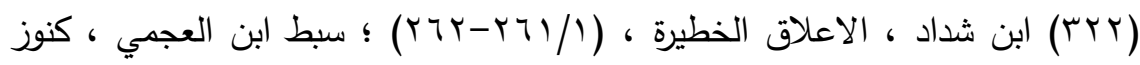

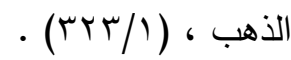

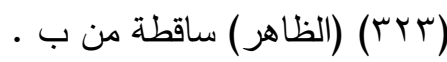

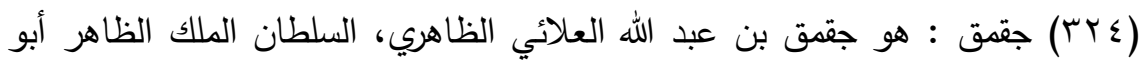

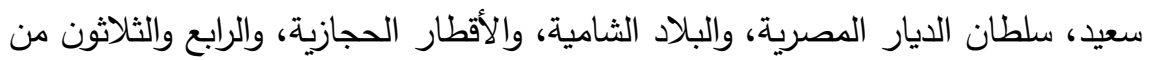

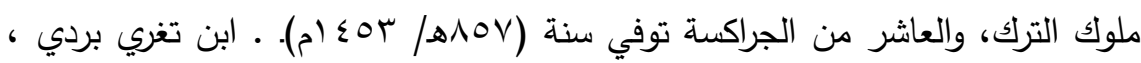

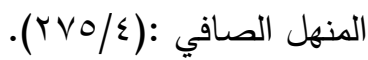

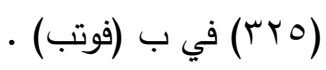

(TrYT) المدرسة البلدقية: هذه المدرسة ظاهر حلب بالقرب من الكلاسين. وكانت كبيرة. فاختصرت وقد دثرت فيما بعد ، أنثأها الأمير حسام الدين بلدق - عتيق الظاهر - وكان منان

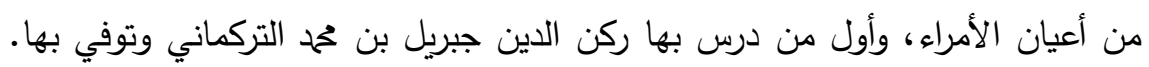

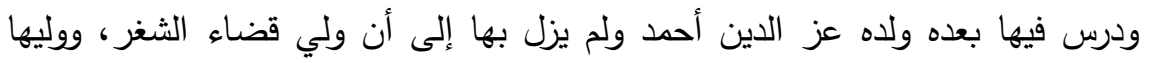


بعده جمال الدين محم المعري وبعد فتتة تمر آل تدريسها للشيخ شرف الدين حمزة

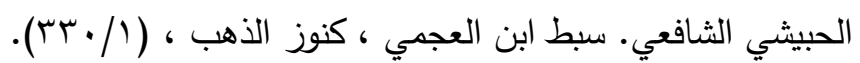

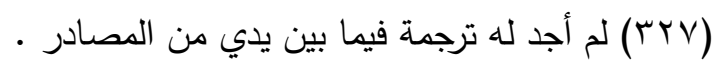
(YYN)

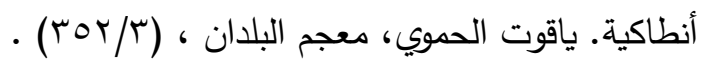

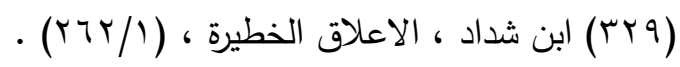

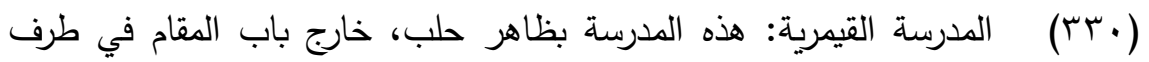
المدارس والترب من القبلة، أنشأها الأمير حسام الدين الحسن بن أبي الفوارس القيمري، لفردي،

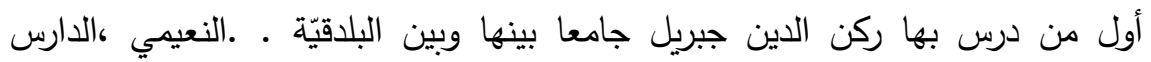

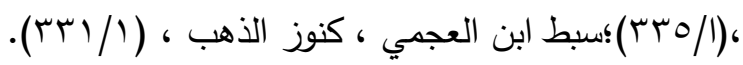

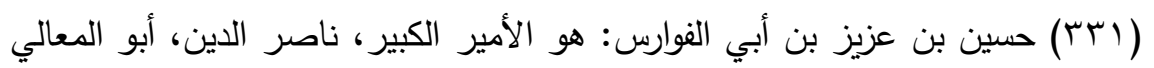

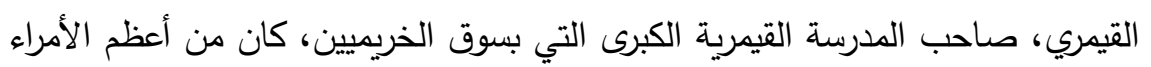

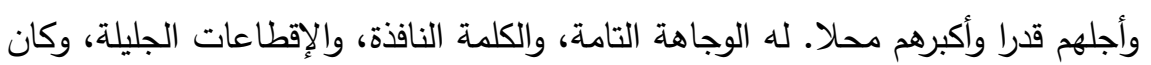
بطلا شجاعا، كريما، عادلا، حازما، رئيسا، كثير البر • وهو الذي ملك الملك الناصر

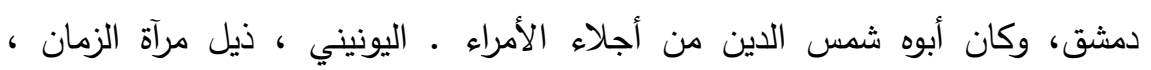

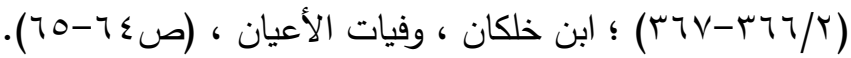

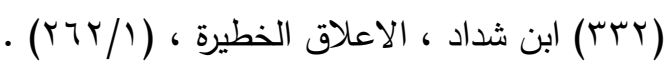

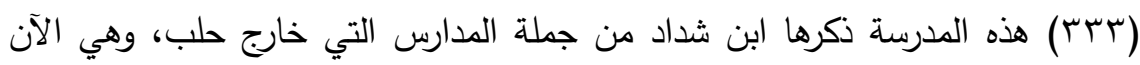

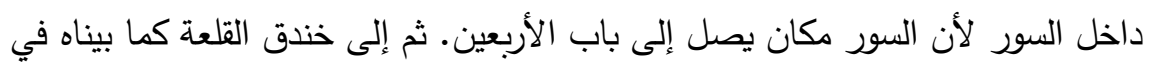

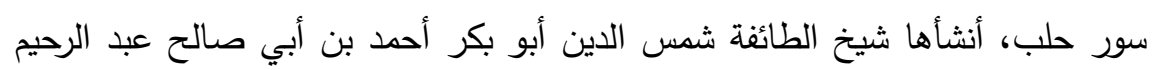

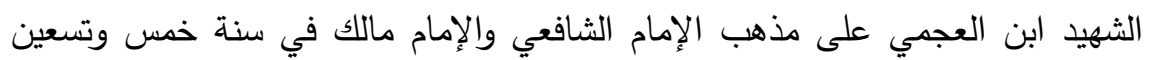

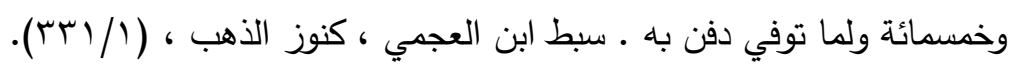

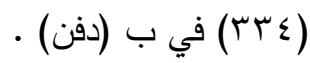

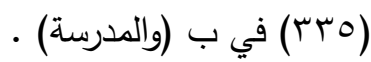

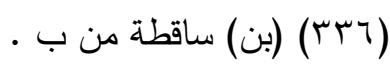

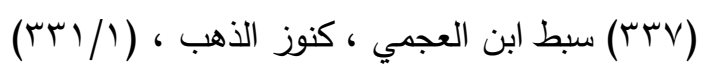


ذكر ما بباطن حلب وظاهرها من المدارس "المدارس الشافعية”
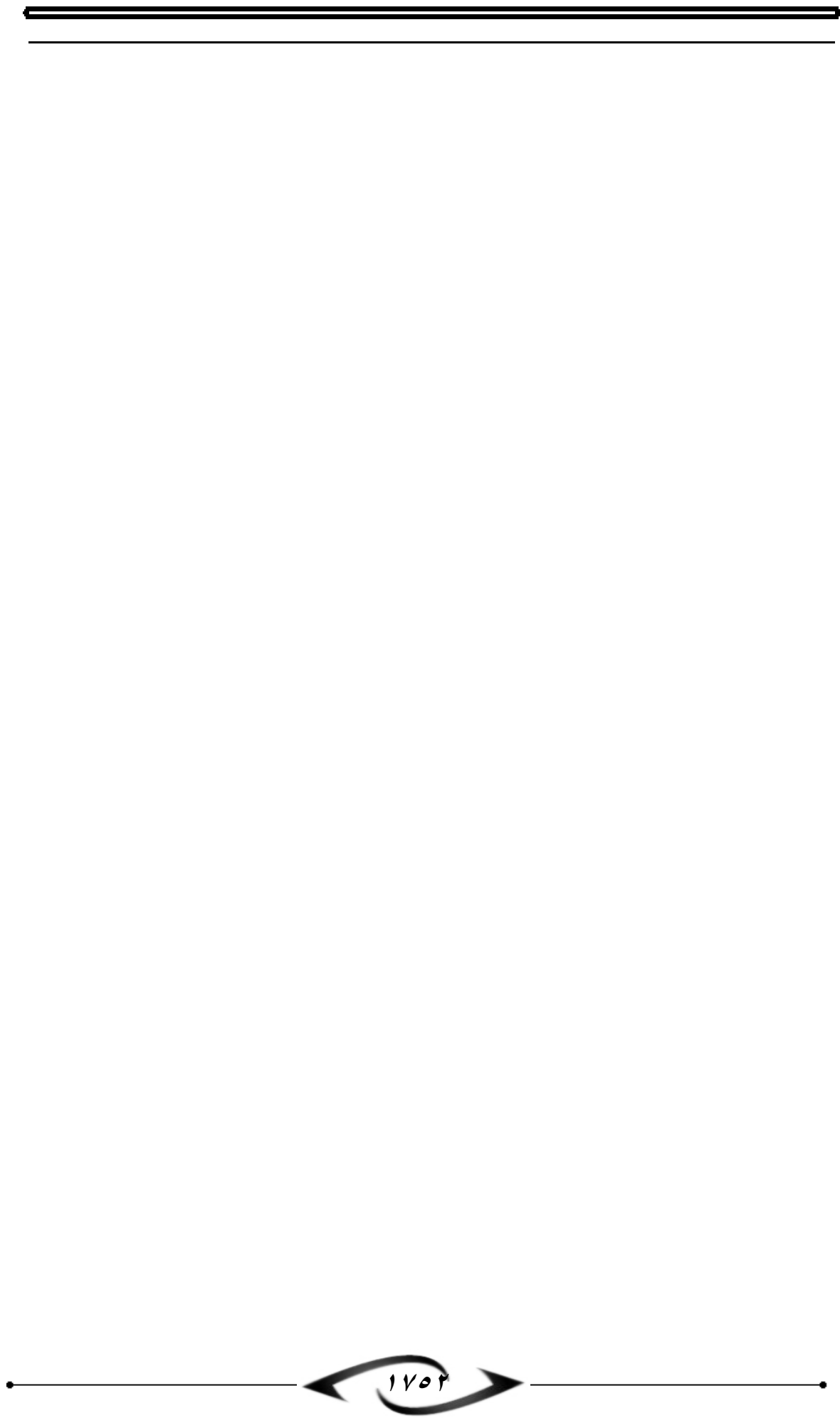